Supporting Information

\title{
Selective Isomerization via Transient Thermodynamic Control: Dynamic Epimerization of trans to cis Diols
}

\author{
Christian J. Oswood and David W. C. MacMillan*
}

Merck Center for Catalysis at Princeton University, Princeton, New Jersey 08544, United States

*Corresponding author. Email: dmacmill@princeton.edu 


\section{Table of Contents}

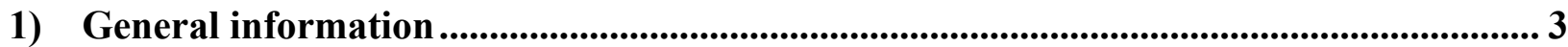

2) Synthesis and characterization of decatungstate HAT catalysts............................................ 4

3) Purification and/or preparation of starting materials ............................................................ 5

4) Standard reaction setup .............................................................................................................. 22

5) Optimization and control experiments ....................................................................................... 27

6) Proposed reaction mechanism and mechanistic experiments ..............................................33

7) Computational investigation of relative stabilities ................................................................... 36

8) General procedure for diastereoselective epimerization .................................................. 42

9) Experimental data for epimerized products ............................................................................... 43

10) Spectra for isolated products................................................................................................... 62

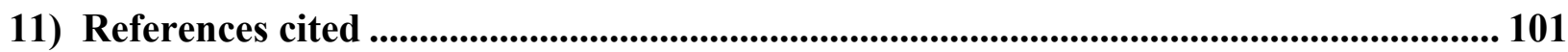




\section{1) General information}

Commercial reagents were used without prior purification unless otherwise indicated. Solvents were dried using a J. C. Meyer solvent purification system. Unless otherwise indicated, filtration of heterogeneous mixtures was performed using ChemRus $20 \mathrm{~mL}$ or $60 \mathrm{~mL}$ disposable filters. Organic solutions were concentrated under reduced pressure on a Büchi rotary evaporator using a water bath.

Chromatographic purification of products was accomplished on a Teledyne ISCO CombiFlash NextGen 300+ with evaporative light scattering detector (ELSD), using Silicycle SiliaSep cartridges unless otherwise noted. Thin-layer chromatography (TLC) was performed on Analtech Uniplate $0.25 \mathrm{~mm}$ silica gel F-254 plates. Visualization of the developed chromatogram was performed by fluorescence quenching or $\mathrm{KMnO}_{4}$ stain.

${ }^{1} \mathrm{H}$ and ${ }^{13} \mathrm{C}$ spectra were recorded on a Bruker Avance III NMR $500 \mathrm{MHz}$ instrument or a Bruker NanoBay Avance III HD NMR $400 \mathrm{MHz}$ instrument, and are internally referenced to the residual proteo-solvent signals (note: $\mathrm{CDCl}_{3}$ referenced at $7.26 \mathrm{ppm}$ and $77.16 \mathrm{ppm}$, respectively; MeCNd3 referenced at 1.94 ppm and 118.26 ppm, respectively; methanol-d4 referenced at 3.31 and 49.00 ppm, respectively; DMSO-d6 referenced at 2.50 and $39.52 \mathrm{ppm}$, respectively; $\mathrm{D}_{2} \mathrm{O}$ referenced at $3.79 \mathrm{ppm}$ and unreferenced, respectively). Data for ${ }^{1} \mathrm{H}$ NMR are reported as follows: chemical shift $(\mathrm{d}$ ppm), multiplicity $(\mathrm{s}=$ singlet, $\mathrm{d}=$ doublet, $\mathrm{t}=$ triplet, $\mathrm{q}=$ quartet, $\mathrm{p}=$ pentet, $\mathrm{h}=$ hextet, hept $=$ heptet, $\mathrm{m}=$ multiplet, $\mathrm{br}=$ broad $)$, coupling constant $(\mathrm{Hz})$, and integration. Data for ${ }^{13} \mathrm{C}$ NMR are reported in terms of chemical shift. Quantitative ${ }^{13} \mathrm{C}$ NMR spectra were taken with a relaxation delay of $30 \mathrm{~s}$. Quantitative ${ }^{1} \mathrm{H}$ NMR spectra were taken with a relaxation delay of $10 \mathrm{~s}$.

Chiral high performance liquid chromatography (HPLC) was performed on an Agilent 1260 Infinity system using chiral columns as noted. Optical rotation $\left([\alpha]_{\mathrm{D}}\right)$ values were recorded on a JASCO P-1010 polarimeter and are reported as specific rotation $\left(\mathrm{deg} \bullet \mathrm{mL} \cdot \mathrm{g}^{-1} \bullet \mathrm{dm}^{-1}\right)$. IR spectra were recorded on a Perkin Elmer Spectrum 100 FTIR spectrometer and are reported in wavenumbers $\left(\mathrm{cm}^{-1}\right)$. High resolution mass spectra (HRMS) were obtained from the Princeton University Mass Spectral Facility. 


\section{2) Synthesis and characterization of decatungstate HAT catalysts}

Tetrabutylammonium decatungstate (TBADT) was synthesized according to a literature procedure $^{1}$.

Tetrabutylphosphonium decatungstate (TBPDT) was synthesized using a modification of the above literature procedure:

To a $250 \mathrm{~mL}$ conical flask with stir bar was added sodium tungstate dihydrate (6.4 g, $19.40 \mathrm{mmol}$, 1 equiv.) and $40 \mathrm{~mL}$ deionized water. This solution was heated to $75^{\circ} \mathrm{C}$, then acidified with 13.4 $\mathrm{mL}$ of $3 \mathrm{M}$ aqueous $\mathrm{HCl}$. The acidified solution was heated at $90{ }^{\circ} \mathrm{C}$ for 10 minutes, then a solution of tetrabutylphosphonium bromide (2.63 g, $7.76 \mathrm{mmol}, 0.4$ equiv.) in $4 \mathrm{~mL}$ deionized water was added in one portion. A gummy yellow precipitate formed immediately on addition of the phosphonium bromide, at which point the solution was stirred for an additional 5 minutes. The reaction mixture was cooled to room temperature, filtered, and the yellow solids collected were rinsed with water. The resulting solids were recrystallized from minimal hot acetone to provide the title compound. Isolated as yellow-green square crystals (1.47 g, 22\% yield). Purity was assessed by UV/vis. spectroscopy $\left(\lambda_{\max }=323 \mathrm{~nm}, \varepsilon_{323}=13526\right.$, absorption consistent with previously reported decatungstate anions).

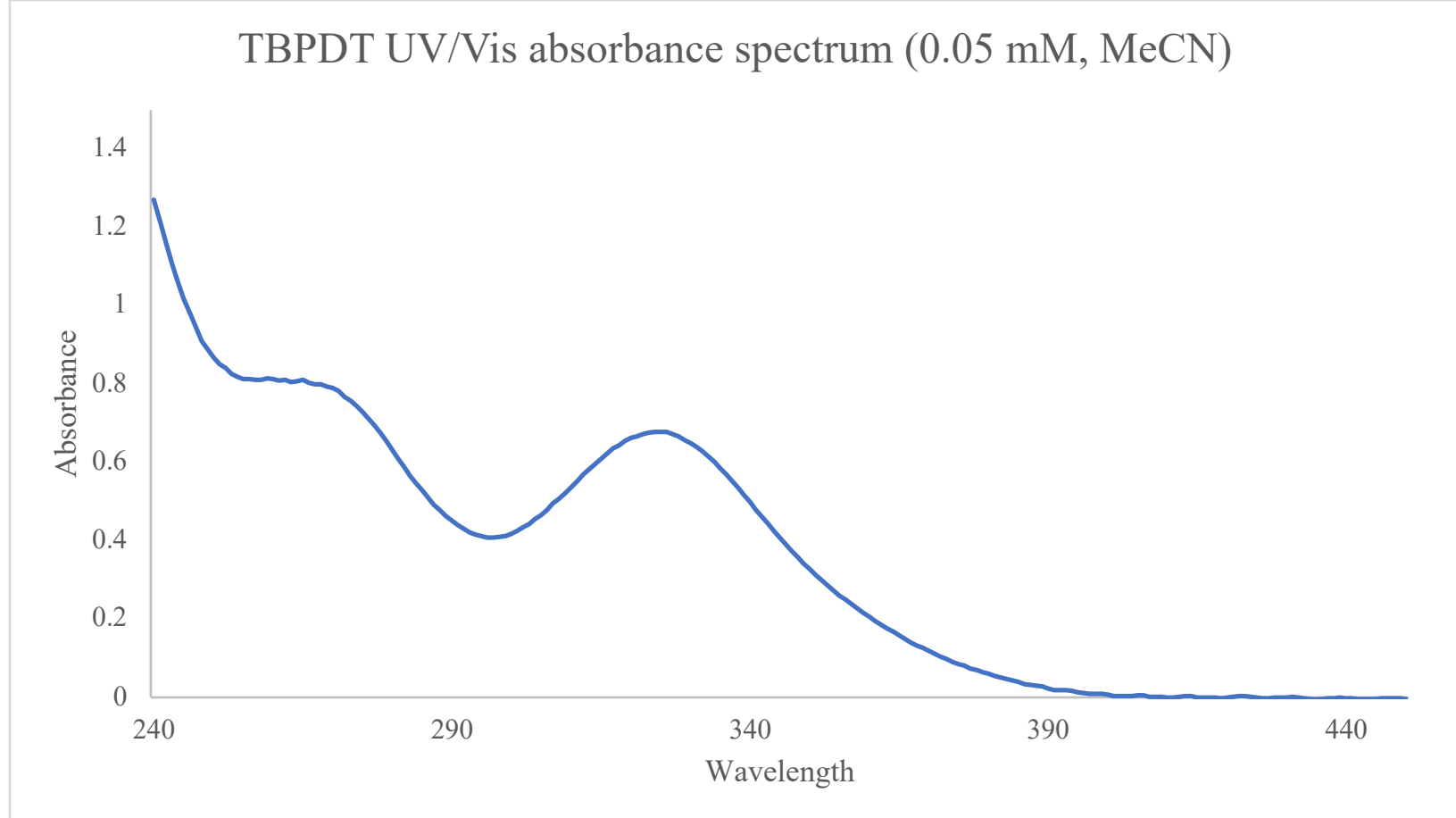




\section{3) Purification and/or preparation of starting materials}

1,3-cyclopentanediol was obtained from Astatech, Inc. as a mixture of cis and trans diastereomers which were separated by flash column chromatography (silica, 0-10\% MeOH/DCM). Trans-2(hydroxymethyl)cyclopentanol was prepared according to a literature procedure. ${ }^{2}$

All other commercially available starting materials were used without prior purification.

\section{(土)-trans-tetrahydropyran-3,4-diol (SM 6)}

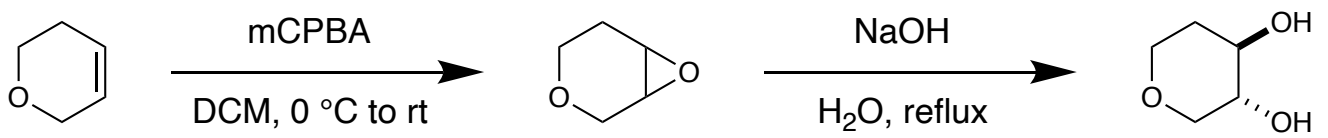

To a $100 \mathrm{~mL}$ round-bottom flask with stir bar was added 3,6-dihydro-2H-pyran ( $0.9 \mathrm{~mL}, 10 \mathrm{mmol}$, 1 equiv.) and dichloromethane $(40 \mathrm{~mL}, 0.25 \mathrm{M})$. The flask was stirred and cooled to $0{ }^{\circ} \mathrm{C}$ in a water/ice bath, then meta-chloroperoxybenzoic acid (mCPBA) $(2.8 \mathrm{~g}$ (77\% pure as mixture with benzoic acid, water), $12.5 \mathrm{mmol}, 1.25$ equiv.) was added as $4 \times 0.7 \mathrm{~g}$ portions. The mixture was stirred for 5 minutes in the ice bath, then removed and stirred at room temperature for 1 hour. The reaction was quenched with $25 \mathrm{~mL} 1 \mathrm{M} \mathrm{K}_{2} \mathrm{CO}_{3}$ solution, stirred for 5 minutes, then the organic and aqueous layers were separated. The aqueous layer was extracted $3 \times$ with DCM, then organic layers were combined and washed with brine, dried over anhydrous $\mathrm{MgSO}_{4}$, filtered and concentrated under vacuum to a clear, colorless oil which was carried forward to hydrolysis without further purification.

To a $250 \mathrm{~mL}$ round-bottom flask with stir bar and reflux condenser was added the crude epoxide (1.0 g, $10 \mathrm{mmol}, 1$ equiv.) and $100 \mathrm{~mL} 1 \mathrm{M}$ aqueous $\mathrm{NaOH}$ solution (10 equiv. $\mathrm{OH}^{-}$). The resulting turbid solution was heated to reflux and maintained at that temperature for 18 hours. The solution was then allowed to cool to room temperature and quenched with $100 \mathrm{~mL}$ of saturated aqueous $\mathrm{NH}_{4} \mathrm{Cl}$ solution. The resulting aqueous solution was concentrated under vacuum to a white solid, triturated $5 \times$ with isopropanol, and the combined isopropanol portions were again concentrated to a thick oil. Purification by flash column chromatography (silica gel, 5-10\% MeOH/DCM gradient followed by $10 \% \mathrm{MeOH} / \mathrm{DCM}$ ) and subsequent removal of solvent provided the title compound as a thick clear oil (357 mg, $3.02 \mathrm{mmol}, 30 \%$ yield). 
${ }^{1} \mathbf{H}$ NMR (500 MHz, $\left.\mathbf{C D C l}_{3}\right) \delta 3.96(\mathrm{dd}, J=5.0,11.1 \mathrm{~Hz}, 1 \mathrm{H}), 3.92(\mathrm{~m}, 1 \mathrm{H}), 3.59(\mathrm{~m}, 1 \mathrm{H}), 3.51$ (m, 1H), 3.41 (td, $J=2.4,11.6 \mathrm{~Hz}, 1 \mathrm{H}), 3.14$ (dd, $J=9.4,11.3 \mathrm{~Hz}, 1 \mathrm{H}), 2.91$ (br s, $2 \mathrm{H}), 1.97$ (m, $1 \mathrm{H}), 1.64(\mathrm{~m}, 1 \mathrm{H})$

${ }^{13} \mathrm{C}$ NMR (126 MHz, $\left.\mathbf{C D C l}_{3}\right) \delta$ 73.0, 72.2, 70.2, 66.3, 33.0

IR (film) $v_{\max } 3346,2857,1378,1224,1064,993,959,897,880,803$

HRMS (EI-TOF) $m / z$ calcd. for $\mathrm{C}_{5} \mathrm{H}_{10} \mathrm{O}_{3}{ }^{+}\left([\mathrm{M}]^{+}\right) 118.06245$, found 118.06302

\section{( \pm )-N-Boc-trans-piperidine-3,4-diol (SM 7)}

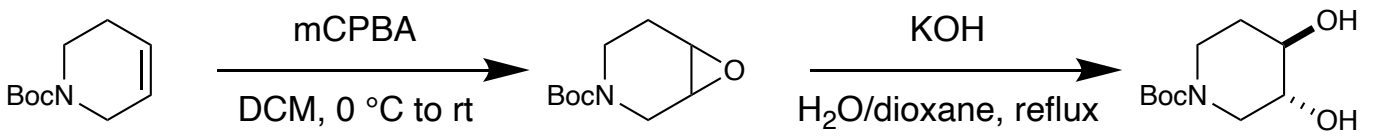

To a $500 \mathrm{~mL}$ round-bottom flask with stir bar was added $N$-Boc-3,6-dihydro-2H-pyridine $(9.16 \mathrm{~g}$, $50 \mathrm{mmol}, 1$ equiv) and dichloromethane $(200 \mathrm{~mL}, 0.25 \mathrm{M})$. The flask was stirred and cooled to 0 ${ }^{\circ} \mathrm{C}$ in a water/ice bath, then meta-chloroperoxybenzoic acid (mCPBA) $(62.5 \mathrm{mmol}, 14.0 \mathrm{~g}(77 \%$ pure as mixture with meta-chlorobenzoic acid, water), 1.25 equiv.) was added in four portions. The mixture was stirred for 5 minutes in the ice bath, then removed and stirred at room temperature for 14 hours. The reaction was quenched with saturated $\mathrm{Na}_{2} \mathrm{~S}_{2} \mathrm{O}_{3}$ solution, stirred for 5 minutes, then the organic and aqueous layers were separated. The organic layer was washed with $2 \times 200$ $\mathrm{mL}$ portions of saturated $\mathrm{NaHCO}_{3}$, then with $100 \mathrm{~mL}$ brine, then dried with anhydrous $\mathrm{MgSO}_{4}$ and concentrated under vacuum to a light yellow oil that was carried forward to hydrolysis without further purification.

To a $1000 \mathrm{~mL}$ round-bottom flask with stir bar and reflux condenser was added the crude epoxide (10.0 g, 50 mmol, 1 equiv.), $250 \mathrm{~mL}$ 1,4-dioxane, and $250 \mathrm{~mL} 1 \mathrm{M}$ aqueous $\mathrm{NaOH}$ solution (5 equiv. $\left.\mathrm{OH}^{-}, 0.1 \mathrm{M}\right)$. The resulting solution was heated to reflux and maintained at that temperature for 14 hours. The solution was then allowed to cool to room temperature and quenched with 200 $\mathrm{mL}$ of saturated aqueous $\mathrm{NH}_{4} \mathrm{Cl}$ solution. The resulting turbid solution was extracted with $4 \times 200$ $\mathrm{mL}$ portions of EtOAc. The organic layers were combined, dried over anhydrous $\mathrm{MgSO}_{4}$, and concentrated to an orange oil. Column chromatography (silica gel, 5-10\% $\mathrm{MeOH} / \mathrm{DCM}$ gradient) 
and subsequent removal of solvent provided the compound as a thick yellow-orange oil (6.19 $\mathrm{g}$, $28.5 \mathrm{mmol}, 57 \%$ yield). ${ }^{1} \mathrm{H}$ NMR shifts were consistent with those reported in the literature. ${ }^{3}$

${ }^{1}$ H NMR (500 MHz, CDCl 3$) \delta 4.17$ (s, 1H), 4.04 (m, 1H), 3.59 - 3.49 (m, 1H), 3.48 - 3.39 (m, $1 \mathrm{H}), 2.91-2.72(\mathrm{~m}, 1 \mathrm{H}), 2.71-2.57(\mathrm{~m}, 1 \mathrm{H}), 2.56-2.24(\mathrm{~m}, 1 \mathrm{H}), 1.99-1.91(\mathrm{~m}, 1 \mathrm{H}), 1.45(\mathrm{~s}$, $9 \mathrm{H})$.

(士)-trans-1,2,3,4-tetrahydronaphthalene-2,3-diol (SM 8)

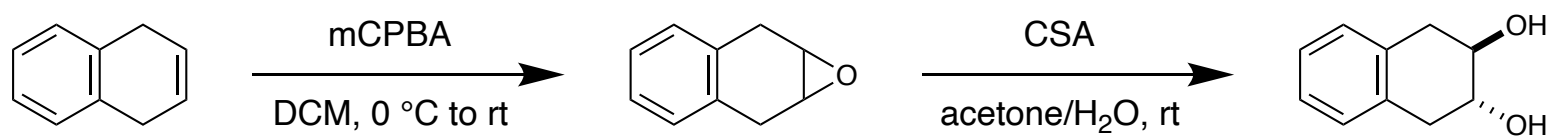

To a $100 \mathrm{~mL}$ round-bottom flask with stir bar was added 1,4-dihydronaphthalene $(7.5 \mathrm{mmol}, .98$ $\mathrm{mL}, 1$ equiv.) and dichloromethane $(30 \mathrm{~mL}, 0.25 \mathrm{M})$. The flask was stirred and cooled to $0{ }^{\circ} \mathrm{C}$ in a water/ice bath, then meta-chloroperoxybenzoic acid (mCPBA) $(9.4 \mathrm{mmol}, 2.1 \mathrm{~g}$ (77\% pure as mixture with meta-chlorobenzoic acid and water), 1.25 equiv.) was added as $3 \times 0.7 \mathrm{~g}$ portions. The mixture was stirred for 5 minutes in the ice bath, then removed and stirred at room temperature for 1 hour. The reaction was quenched with $25 \mathrm{~mL} 1 \mathrm{M} \mathrm{K}_{2} \mathrm{CO}_{3}$, stirred for 5 minutes, then the organic and aqueous layers were separated. The aqueous layer was extracted $3 \times$ with DCM, then organic layers were combined and washed with brine, dried over anhydrous $\mathrm{MgSO}_{4}$, filtered and concentrated under vacuum to a clear, colorless oil which was used without further purification.

To a $250 \mathrm{~mL}$ round-bottom flask with stir bar was added epoxide (1.1 g, $7.5 \mathrm{mmol}$, 1 equiv.),

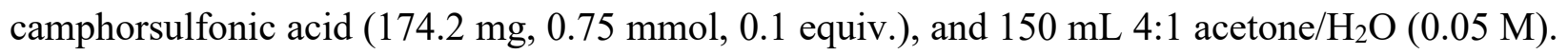
The resulting solution was stirred at room temperature for 3 days, monitoring conversion by TLC. Once the reaction was complete, the organic solvents were removed under vacuum. The resulting aqueous solution was extracted $3 \times$ with EtOAc, and the organic layers were washed with brine, dried over anhydrous $\mathrm{MgSO}_{4}$, filtered, and concentrated. Purification by flash column chromatography (silica, dry load, $0-5 \% \mathrm{MeOH} / \mathrm{DCM}$ ), subsequent removal of solvent, and recrystallization from minimal hot acetone provided the diastereopure title compound (431 mg, $2.6 \mathrm{mmol}, 35 \%$ yield). ${ }^{1} \mathrm{H}$ NMR shifts were consistent with those reported in the literature. ${ }^{4}$ 
${ }^{1}$ H NMR (500 MHz, CDCl $) \delta 7.17-7.08(\mathrm{~m}, 4 \mathrm{H}), 3.99-3.81(\mathrm{~m}, 2 \mathrm{H}), 3.21(\mathrm{~m}, 2 \mathrm{H}), 3.01-$ $2.71(\mathrm{~m}, 2 \mathrm{H})$

\section{(土)-trans-1-methylcyclohexane-1,2-diol (SM 9)}

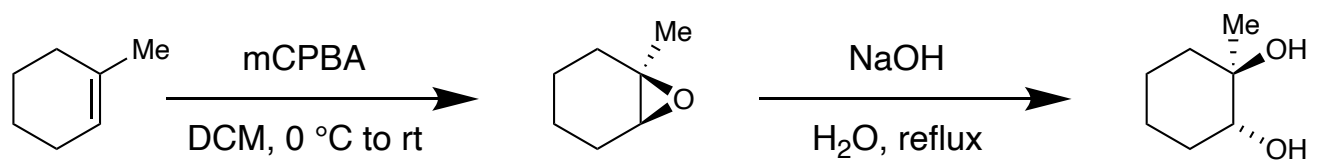

To a $100 \mathrm{~mL}$ round-bottom flask with stir bar was added 1-phenyl-cyclohex-1-ene (10 mmol, 1.6 $\mathrm{mL}, 1$ equiv.) and dichloromethane $\left(40 \mathrm{~mL}, 0.25 \mathrm{M}\right.$. The flask was stirred and cooled to $0{ }^{\circ} \mathrm{C}$ in a water/ice bath, then meta-chloroperoxybenzoic acid (mCPBA) (12.5 mmol, $2.8 \mathrm{~g}$ (77\% pure as mixture with meta-chlorobenzoic acid, water), 1.25 equiv.) was added as $4 \times 0.7 \mathrm{~g}$ portions. The mixture was stirred for 5 minutes in the ice bath, then removed and stirred at room temperature for 1 hour. The reaction was quenched with $25 \mathrm{~mL}$ saturated $\mathrm{Na}_{2} \mathrm{~S}_{2} \mathrm{O}_{3}$ solution, stirred for 5 minutes, then the organic and aqueous layers were separated. The aqueous layer was extracted $3 \times$ with DCM, then organic layers were combined and washed with brine, dried over anhydrous $\mathrm{MgSO}_{4}$, filtered and concentrated under vacuum to a clear, colorless oil which was used without purification.

To a $250 \mathrm{~mL}$ round-bottom flask with stir bar and reflux condenser was added the crude epoxide (1.12 g, 10 mmol, 1 equiv.) and $100 \mathrm{~mL} 1 \mathrm{M}$ aqueous $\mathrm{NaOH}$ solution (10 equiv. $\mathrm{OH}^{-}$). The resulting turbid solution was heated to reflux and maintained at that temperature for 17 hours. The solution was then allowed to cool to room temperature and quenched with $100 \mathrm{~mL}$ of saturated aqueous $\mathrm{NH}_{4} \mathrm{Cl}$ solution. The resulting aqueous solution was extracted $5 \times$ with $50 \mathrm{~mL}$ EtOAc, then organic layers were combined, washed with brine, dried over anhydrous $\mathrm{MgSO}_{4}$ and filtered. Removal of solvent provided the title compound as an off-white solid (684 mg, $5.3 \mathrm{mmol}, 53 \%$ yield). ${ }^{1} \mathrm{H}$ NMR shifts were consistent with those reported in the literature. ${ }^{5}$

${ }^{1}$ H NMR (500 MHz, CD $\mathbf{C}$ CN) $\delta 3.32(\mathrm{~m}, 1 \mathrm{H}), 2.75-2.66(\mathrm{~m}, 1 \mathrm{H}), 2.52(\mathrm{~s}, 1 \mathrm{H}), 1.78-1.70(\mathrm{~m}$, $1 \mathrm{H}), 1.65-1.50(\mathrm{~m}, 3 \mathrm{H}), 1.37-1.22(\mathrm{~m}, 4 \mathrm{H}), 1.08(\mathrm{~s}, 3 \mathrm{H})$. 


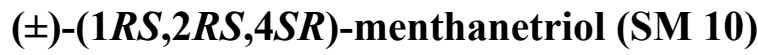

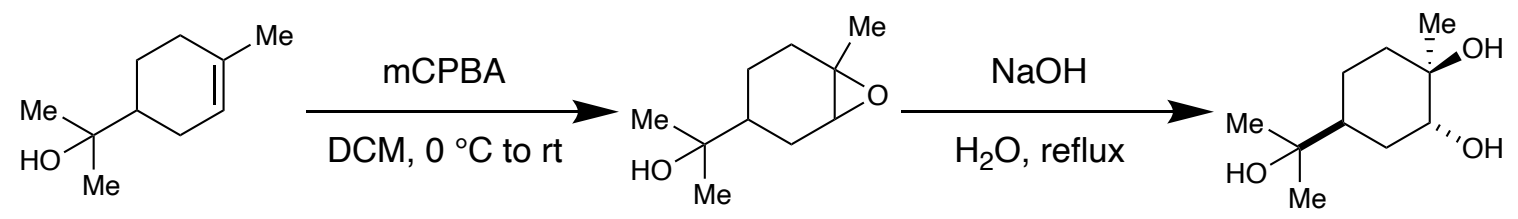

To a $500 \mathrm{~mL}$ round-bottom flask with stir bar was added a-terpinyl acetate $(5.15 \mathrm{~mL}, 25 \mathrm{mmol}, 1$ equiv.), dichloromethane (100 mL) and saturated aqueous $\mathrm{NaHCO}_{3}(100 \mathrm{~mL}$, reaction concentration $0.125 \mathrm{M}$ ). The flask was stirred and cooled to $0{ }^{\circ} \mathrm{C}$ in a water/ice bath, then $m e t a$ chloroperoxybenzoic acid (mCPBA) (7.0 g $31.25 \mathrm{mmol}$ (77\% pure as mixture with metachlorobenzoic acid, water), 1.25 equiv.) was added as $4 \times 1.75 \mathrm{~g}$ portions. The mixture was stirred for 5 minutes in the ice bath, then removed and stirred at room temperature for 1 hour. The reaction was quenched with saturated aqueous $\mathrm{Na}_{2} \mathrm{~S}_{2} \mathrm{O}_{3}$, stirred for 5 minutes, then the organic and aqueous layers were separated. The aqueous layer was extracted with $2 \times 100 \mathrm{~mL}$ portions of DCM, then organic layers were combined and washed with brine, dried over anhydrous $\mathrm{MgSO}_{4}$, filtered and concentrated under vacuum to a clear, colorless oil which was used without further purification.

To a $250 \mathrm{~mL}$ round-bottom flask with stir bar and reflux condenser was added the crude epoxide (6.58 g, $25 \mathrm{mmol}, 1$ equiv.) and $250 \mathrm{~mL} 1 \mathrm{M}$ aqueous $\mathrm{NaOH}$ solution (10 equiv. $\mathrm{OH}^{-}$). The resulting turbid solution was heated to reflux and maintained at that temperature for 14 hours. The solution was then allowed to cool to room temperature and neutralized with $60 \mathrm{~mL} 2 \mathrm{M}$ aqueous $\mathrm{H}_{2} \mathrm{SO}_{4}$. The resulting aqueous solution was concentrated under vacuum to an orange solid and triturated with $5 \times 100 \mathrm{~mL}$ acetonitrile. The organic solutions were combined, dried with anhydrous $\mathrm{MgSO}_{4}$, and solvent was again removed under vacuum. Purification by flash column chromatography (silica gel, 5-10\% MeOH/DCM gradient then 10\% MeOH/DCM) and subsequent removal of solvent provided the title compound as a white solid (1.84 g, $9.8 \mathrm{mmol}, 39 \%$ yield). ${ }^{13} \mathrm{C}$ NMR (acetone- $\mathrm{d}_{6}$ ) shifts were consistent with those reported in the literature for the $(1 S, 2 S, 4 R)$ isomer. $^{6}$

${ }^{1}$ H NMR (400 MHz, CD 3 CN) $\delta 3.47-3.41(\mathrm{~m}, 1 \mathrm{H}), 2.64(\mathrm{~s}, 0 \mathrm{H}), 2.27(\mathrm{~s}, 1 \mathrm{H}), 2.16(\mathrm{~s}, 1 \mathrm{H}), 1.68$ $-1.46(\mathrm{~m}, 4 \mathrm{H}), 1.43-1.26(\mathrm{~m}, 2 \mathrm{H}), 1.12(\mathrm{~s}, 2 \mathrm{H}), 1.08(\mathrm{~s}, 6 \mathrm{H})$.

${ }^{13}$ C NMR (126 MHz, Acetone-d6) $\delta$ 74.40, 71.86, 70.76, 41.95, 34.60, 31.09, 28.22, 27.61, 27.40, 22.86 . 
trans-tetrahydrofuran-3,4-diol (SM 12)

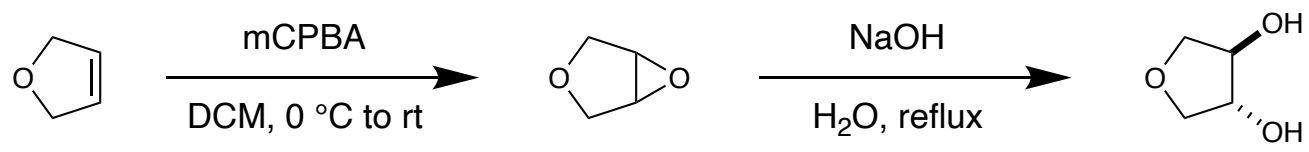

To a $100 \mathrm{~mL}$ round-bottom flask with stir bar was added 1,4-dihydronaphthalene (10 mmol, .76 $\mathrm{mL}, 1$ equiv.) and dichloromethane $(40 \mathrm{~mL}, 0.25 \mathrm{M})$. The flask was stirred and cooled to $0{ }^{\circ} \mathrm{C}$ in a water/ice bath, then meta-chloroperoxybenzoic acid (mCPBA) (12.5 mmol, $2.4 \mathrm{~g}$ (77\% pure as mixture with meta-chlorobenzoic acid, water), 1.25 equiv.) was added as $4 \times 0.7 \mathrm{~g}$ portions. The mixture was stirred for 5 minutes in the ice bath, then removed and stirred at room temperature for 23 hours. The reaction was quenched with $50 \mathrm{~mL} 1 \mathrm{M} \mathrm{K}_{2} \mathrm{CO}_{3}$, stirred for 5 minutes, then the organic and aqueous layers were separated. The aqueous layer was extracted $3 \times$ with DCM, then organic layers were combined and washed with brine, dried over anhydrous $\mathrm{MgSO}_{4}$, filtered and concentrated under vacuum to a clear, colorless oil which was used without further purification.

To a $250 \mathrm{~mL}$ round-bottom flask with stir bar and reflux condenser was added the crude epoxide (731 mg, 8.5 mmol, 1 equiv.) and $85 \mathrm{~mL} 1 \mathrm{M}$ aqueous $\mathrm{NaOH}$ solution (10 equiv. $\mathrm{OH}^{-}$). The resulting turbid solution was heated to reflux and maintained at that temperature for 24 hours. The solution was then allowed to cool to room temperature and neutralized with $1 \mathrm{M}$ aqueous $\mathrm{HCl}$. The resulting aqueous solution was concentrated under vacuum to a white solid, triturated $5 \times$ with isopropyl alcohol, and the combined isopropyl alcohol was again concentrated to a thick oil. Purification by flash column chromatography (silica gel, 5-10\% MeOH/DCM gradient) and subsequent removal of solvent provided the title compound as a thick clear oil (416 mg, $4.0 \mathrm{mmol}$, $47 \%$ yield). ${ }^{1} \mathrm{H}$ NMR shifts were consistent with those reported in the literature. ${ }^{7}$

${ }^{1}$ H NMR (500 MHz, CDCl $)_{3} \delta 4.29-4.21$ (m, 2H), 4.09 (dd, $\left.J=10.1,3.8 \mathrm{~Hz}, 2 \mathrm{H}\right), 3.74(\mathrm{~m}, 2 \mathrm{H})$. 


\section{$(R, R)$-N-Boc-pyrrolidine-3,4-diol (SM 13)}

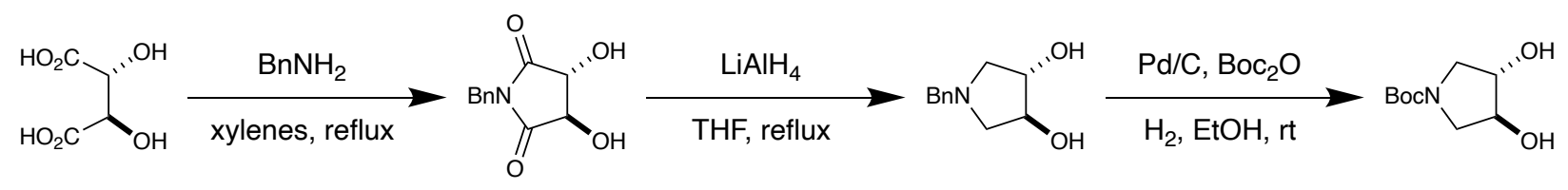

$(R, R)$ - $N$-benzyl-pyrrolidine-3,4-diol was prepared in two steps from L-tartaric acid and benzylamine according to literature procedures. ${ }^{8}$

$(R, R)-N$-Boc-pyrrolidine-3,4-diol was prepared with an adaptation of a previously reported procedure. ${ }^{9}$ Under an inert atmosphere, to a $50 \mathrm{~mL}$ three-neck round-bottom flask was added $10 \%$ palladium on carbon $(80 \mathrm{mg})$, followed by a sparged solution of $(R, R)$-N-benzyl-pyrrolidine-3,4diol (483 mg, $2.5 \mathrm{mmol}$ ) and di-tert-butyl dicarbonate (600 mg, $2.75 \mathrm{mmol}, 1.1$ equiv.) in ethanol $(17 \mathrm{~mL}, 0.15 \mathrm{M})$. The nitrogen atmosphere was exchanged for $\mathrm{H}_{2}$, and the reaction mixture was stirred under an atmosphere of $\mathrm{H}_{2}$ (balloon) for 20 hours at room temperature. After reaction completion, the reaction was exposed to air, the solution was filtered through a pad of Celite and solvent was removed under vacuum. Recrystallization from minimal hot EtOAc provided the title compound as clear crystals (330 mg, $1.6 \mathrm{mmol}, 65 \%$ yield). ${ }^{1} \mathrm{H}$ NMR shifts were consistent with those reported in the literature. ${ }^{10}$

${ }^{1}$ H NMR (500 MHz, CDCl$_{3}$ ) $\delta 4.26$ - 3.92 (br s, 2H), 3.81 - 3.57 (m, 2H), 3.37 (br s, 2H), 1.47 $(\mathrm{s}, 9 \mathrm{H})$.

( \pm )-trans-1-methylcyclopentane-1,2-diol (SM 14)

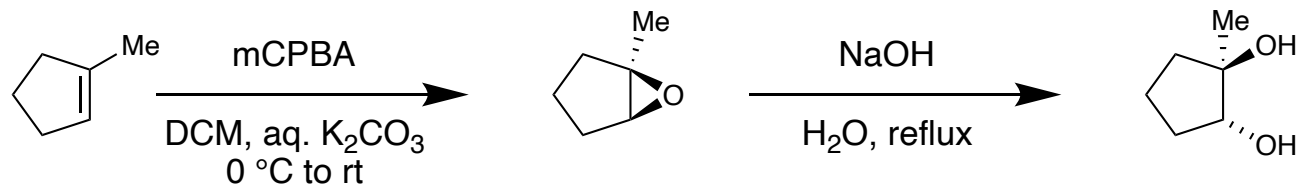

To a $100 \mathrm{~mL}$ round-bottom flask with stir bar was added 1-methyl-cyclopent-1-ene (10 mmol, $1.05 \mathrm{~mL}, 1$ equiv.), dichloromethane $(40 \mathrm{~mL})$, and saturated aqueous $\mathrm{NaHCO}_{3}(40 \mathrm{~mL}$, reaction concentration $0.125 \mathrm{M}$ ). The flask was stirred and cooled to $0{ }^{\circ} \mathrm{C}$ in a water/ice bath, then $m e t a$ chloroperoxybenzoic acid (mCPBA) (12.5 mmol, $2.8 \mathrm{~g}$ (77\% pure as mixture with meta-chlorobenzoic acid, water), 1.25 equiv.) was added as $4 \times 0.7$ g portions. The mixture was stirred for 5 
minutes in the ice bath, then removed and stirred at room temperature for 1 hour. The reaction was quenched with $25 \mathrm{~mL}$ saturated $\mathrm{Na}_{2} \mathrm{~S}_{2} \mathrm{O}_{3}$ solution, stirred for 5 minutes, then the organic and aqueous layers were separated. The aqueous layer was extracted $3 \times$ with DCM, then organic layers were combined and washed with brine, dried over anhydrous $\mathrm{MgSO}_{4}$, filtered and concentrated under vacuum to a clear, colorless oil which was carried forward to hydrolysis without purification.

To a $250 \mathrm{~mL}$ round-bottom flask with stir bar and reflux condenser was added the crude epoxide (687 mg, $7 \mathrm{mmol}, 1$ equiv.) and $70 \mathrm{~mL} 1 \mathrm{M}$ aqueous $\mathrm{NaOH}$ solution (10 equiv. $\mathrm{OH}^{-}$). The resulting turbid solution was heated to reflux and maintained at that temperature for 24 hours. The solution was then allowed to cool to room temperature and quenched with $70 \mathrm{~mL}$ of saturated aqueous $\mathrm{NH}_{4} \mathrm{Cl}$ solution. The resulting aqueous solution was extracted $5 \times$ with $50 \mathrm{~mL}$ EtOAc, then organic layers were combined, washed with brine, dried over anhydrous $\mathrm{MgSO}_{4}$ and filtered. Removal of solvent under vacuum provided the title compound as a white solid ( $247 \mathrm{mg}, 2.1 \mathrm{mmol}, 30 \%$ yield).

${ }^{1}$ H NMR (500 MHz, CDCl $) \delta 3.93-3.80(\mathrm{~m}, 1 \mathrm{H}), 2.23-2.08(\mathrm{~m}, 1 \mathrm{H}), 1.85-1.69$ (m, 3H), $1.69-1.62(\mathrm{~m}, 1 \mathrm{H}), 1.62-1.49(\mathrm{~m}, 1 \mathrm{H}), 1.32(\mathrm{~s}, 3 \mathrm{H})$.

${ }^{13}$ C NMR (126 MHz, $\left.\mathbf{C D C l}_{3}\right) \delta 81.28,80.74,37.44,32.24,22.17,19.78$.

IR (film) $v_{\max } 3270,2965,1411,1307,1095,1053,994,972,918,878$

HRMS (EI-TOF) $m / z$ calcd. for $\mathrm{C}_{6} \mathrm{H}_{12} \mathrm{O}_{2}{ }^{+}\left([\mathrm{M}]^{+}\right) 116.08318$, found 116.08351

\section{( \pm )-trans-cycloheptane-1,2-diol (SM 15)}
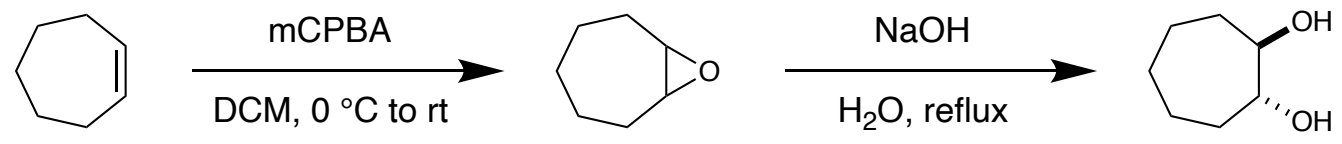

To a $250 \mathrm{~mL}$ round-bottom flask with stir bar was added cycloheptene (20 mmol, $2.3 \mathrm{~mL}, 1$ equiv.) and dichloromethane $(80 \mathrm{~mL}, 0.25 \mathrm{M})$. The flask was stirred and cooled to $0{ }^{\circ} \mathrm{C}$ in a water/ice bath, then meta-chloroperoxybenzoic acid (mCPBA) (25 mmol, $5.6 \mathrm{~g}$ (77\% pure as mixture with meta-chlorobenzoic acid, water), 1.25 equiv.) was added as $4 \times 1.4 \mathrm{~g}$ portions. The mixture was stirred for 5 minutes in the ice bath, then removed and stirred at room temperature for 3 hours. The reaction was quenched with $25 \mathrm{~mL}$ saturated $\mathrm{Na}_{2} \mathrm{~S}_{2} \mathrm{O}_{3}$ solution, stirred for 5 minutes, then the organic and aqueous layers were separated. The aqueous layer was extracted $3 \times$ with DCM, then organic layers were combined and washed with brine, dried over anhydrous $\mathrm{MgSO}_{4}$, filtered and 
concentrated under vacuum to a clear, colorless oil which was carried forward to hydrolysis without further purification.

To a $500 \mathrm{~mL}$ round-bottom flask with stir bar and reflux condenser was added the crude epoxide (2.24 g, 20 mmol, 1 equiv.) and $200 \mathrm{~mL} 1 \mathrm{M}$ aqueous $\mathrm{NaOH}$ solution (10 equiv. $\mathrm{OH}^{-}$). The resulting turbid solution was heated to reflux and maintained at that temperature for 22 hours. The solution was then allowed to cool to room temperature and quenched with $200 \mathrm{~mL}$ of saturated aqueous $\mathrm{NH}_{4} \mathrm{Cl}$ solution. The resulting aqueous solution was extracted $4 \times$ with EtOAc, then organic layers were combined, washed with brine, dried over anhydrous $\mathrm{MgSO}_{4}$ and filtered. Removal of solvent under vacuum provided the title compound as a white solid (1.53 g, $11.7 \mathrm{mmol}$, $59 \%$ yield. ${ }^{1} \mathrm{H}$ NMR shifts were consistent with those reported in the literature. ${ }^{11}$

${ }^{1}$ H NMR (500 MHz, $\left.\mathbf{C D C l}_{3}\right) \delta 3.58-3.32(\mathrm{~m}, 2 \mathrm{H}), 2.26(\mathrm{~s}, 2 \mathrm{H}), 2.10-1.80(\mathrm{~m}, 2 \mathrm{H}), 1.67(\mathrm{~m}$, $2 \mathrm{H}), 1.50(\mathrm{~m}, 6 \mathrm{H})$.

\section{( \pm -trans-1,2-cyclobutanediol (SM 16)}
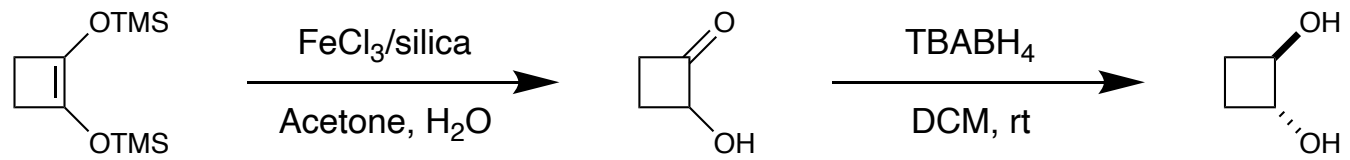

Trans-1,2-cyclobutanediol was prepared from 1,2-bis(trimethylsiloxy)cyclobutene in two steps by modified literature procedures. ${ }^{12}$

To a $25 \mathrm{~mL}$ round-bottom flask with stir bar was added sequentially acetone $(6 \mathrm{~mL}, 1.7 \mathrm{M}), 1,2-$ bis(trimethylsiloxy)cyclobutene (2.6 mL, $10 \mathrm{mmol}, 1$ equiv.), water (0.36 mL, $20 \mathrm{mmol}, 2$ equiv.), and $\mathrm{FeCl}_{3} / \mathrm{SiO}_{2}(6: 100,10 \mathrm{mg})$. The resulting yellow solution was stirred at room temperature for 45 minutes. Solvent was then removed under vacuum and the resulting yellow oil was filtered through a short silica pad eluted with ether. Solvent was again removed under vacuum and the resulting crude 2-hydroxycyclobutanone was immediately used in the following step without further purification due to its instability.

To a $100 \mathrm{~mL}$ round-bottom flask with stir bar was added the crude 2-hydroxycyclobutanone, 40 $\mathrm{mL} \operatorname{DCM}(0.25 \mathrm{M})$ and tetrabutylammonium borohydride (2.57 g, $10 \mathrm{mmol}, 1$ equiv.). Gas evolution was observed upon addition of the borohydride reagent. The resulting solution was stirred at room temperature for 15 minutes, then quenched with $4 \mathrm{M}$ aqueous $\mathrm{HCl}(5 \mathrm{~mL})$. An 
additional $5 \mathrm{~mL}$ brine were then added, and the aqueous layer was saturated with $\mathrm{NaCl}$. The organic layer was then separated, dried with anhydrous $\mathrm{MgSO}_{4}$, and solvent was removed under vacuum. The resulting oil was triturated with $3 \times 50 \mathrm{~mL}$ portions of $\mathrm{Et}_{2} \mathrm{O}$, which were combined and then evaporated under vacuum. Purification by flash column chromatography (silica, 0-10\% $\mathrm{MeOH} / \mathrm{DCM}$ gradient followed by $10 \% \mathrm{MeOH} / \mathrm{DCM}$ ) and subsequent removal of solvent under vacuum yielded the title compound as a clear oil that solidified upon standing (112 mg, $1.3 \mathrm{mmol}$, $13 \%$ yield over two steps).

${ }^{1}$ H NMR (500 MHz, CD $\left.{ }_{3} \mathbf{C N}\right) \delta 3.77-3.68(\mathrm{~m}, 2 \mathrm{H}), 3.21(\mathrm{~s}, 2 \mathrm{H}), 1.92-1.83(\mathrm{~m}, 2 \mathrm{H}), 1.23-$ $1.11(\mathrm{~m}, 2 \mathrm{H})$.

${ }^{13}$ C NMR (126 MHz, $\left.\mathbf{C D C l}_{3}\right) \delta$ 75.75, 22.97.

IR (film) $v_{\max } 3230,2993,2955,1711,1446,1312,1224,1140,1083,1055,911$

HRMS (EI-TOF) $\mathrm{m} / z$ calcd. for $\mathrm{C}_{4} \mathrm{H}_{8} \mathrm{O}_{2}{ }^{+}\left([\mathrm{M}]^{+}\right)$88.05188, found 88.05185

meso-3,4-hexanediol (SM 17)

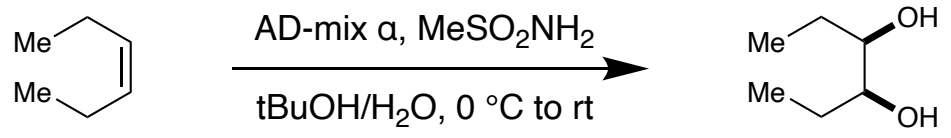

To a $50 \mathrm{~mL}$ round-bottom flask with stir bar was added 1:1 water/tert-butanol $(20 \mathrm{~mL}, 0.1 \mathrm{M})$, AD-mix a (2.8 g), and methanesulfonamide (190 mg, 1 equiv.). The resulting orange solution was cooled to $0^{\circ} \mathrm{C}$ in an ice bath and cis-3-hexene was added via syringe ( $0.25 \mathrm{~mL}, 2 \mathrm{mmol}, 1$ equiv.). The resulting orange slurry was stirred vigorously overnight at room temperature. Upon reaction completion, $\mathrm{Na}_{2} \mathrm{SO}_{3}(3 \mathrm{~g})$ was added, and the mixture was stirred for $30 \mathrm{~m} .20 \mathrm{~mL}$ EtOAc were added, the organic and aqueous layers were separated, and the aqueous layer was extracted $3 \times$ with $10 \mathrm{~mL}$ portions of EtOAc. The organic layers were combined, washed sequentially with $1 \mathrm{M}$ aqueous $\mathrm{NaOH}$ and brine, dried over $\mathrm{MgSO}$, and concentrated under vacuum. Purification by flash column chromatography (silica gel, 1:1 EtOAc/hexanes) and subsequent removal of solvent provided the title compound as a white solid (134 mg, $1.1 \mathrm{mmol}, 57 \%$ yield). ${ }^{1} \mathrm{H}$ NMR shifts were consistent with those reported in the literature. ${ }^{13}$

${ }^{1}$ H NMR (400 MHz, CDCl 3$) \delta 3.76-3.44(\mathrm{~m}, 2 \mathrm{H}), 1.77(\mathrm{~d}, J=5.0 \mathrm{~Hz}, 2 \mathrm{H}), 1.60-1.38(\mathrm{~m}, 4 \mathrm{H})$, $1.00(\mathrm{t}, J=7.4 \mathrm{~Hz}, 6 \mathrm{H})$. 


\section{( \pm )-syn-4-methylpentane-2,3-diol (SM 18a)}
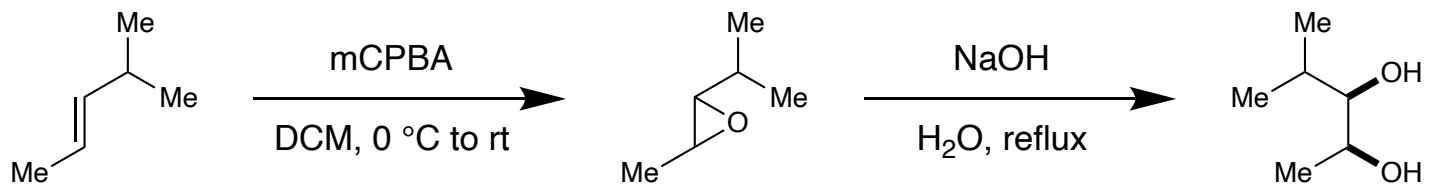

To a $250 \mathrm{~mL}$ round-bottom flask with stir bar was added trans-4-methyl-2-pentene (25 mmol, 3.1 $\mathrm{mL}, 1$ equiv.) and dichloromethane $(100 \mathrm{~mL}, 0.25 \mathrm{M})$. The flask was stirred and cooled to $0{ }^{\circ} \mathrm{C}$ in a water/ice bath, then meta-chloroperoxybenzoic acid (mCPBA) $(31.3 \mathrm{mmol}, 7.0 \mathrm{~g}$ (77\% pure as mixture with meta-chlorobenzoic acid, water), 1.25 equiv.) was added as $4 \times 1.75 \mathrm{~g}$ portions. The mixture was stirred for 5 minutes in the ice bath, then removed and stirred at room temperature for 3 hours. The reaction was quenched with saturated $\mathrm{Na}_{2} \mathrm{~S}_{2} \mathrm{O}_{3}$ solution and saturated $\mathrm{NaHCO}_{3}$ solution, then the organic and aqueous layers were separated. The aqueous layer was extracted 3 $\times$ with DCM, then organic layers were combined and washed with brine, dried over anhydrous $\mathrm{MgSO}_{4}$, filtered and concentrated under vacuum to a clear, colorless oil which was carried forward to hydrolysis without further purification. Note: DCM was not completely removed due to volatility of the epoxide.

To a $250 \mathrm{~mL}$ round-bottom flask with stir bar and reflux condenser was added the crude epoxide (1.4 g, $10 \mathrm{mmol}, 1$ equiv., 72\% pure with remaining mass being DCM) and $100 \mathrm{~mL} 1 \mathrm{M}$ aqueous $\mathrm{NaOH}$ solution (10 equiv. $\mathrm{OH}^{-}$). The resulting turbid solution was heated to reflux and maintained at that temperature for 22 hours. The solution was then allowed to cool to room temperature and quenched with $75 \mathrm{~mL}$ of saturated aqueous $\mathrm{NH}_{4} \mathrm{Cl}$ solution. The resulting aqueous solution was extracted $5 \times$ with EtOAc, then organic layers were combined, washed with brine, dried over anhydrous $\mathrm{MgSO}_{4}$, filtered, and concentrated under vacuum to yield a clear oil. Purification by flash column chromatography (silica gel, 1:1 EtOAc/hexanes) and subsequent removal of solvent provided the title compound as a white solid (768 $\mathrm{mg}, 6.5 \mathrm{mmol}, 65 \%$ yield). ${ }^{1} \mathrm{H}$ NMR shifts were consistent with those reported in the literature. ${ }^{14}$

${ }^{1}$ H NMR (400 MHz, CDCl $)$ ) $3.98-3.86(\mathrm{~m}, 1 \mathrm{H}), 3.29$ (dt, $\left.J=8.0,3.9 \mathrm{~Hz}, 1 \mathrm{H}\right), 1.89$ (d, $J=4.1$ $\mathrm{Hz}, 1 \mathrm{H}), 1.72(\mathrm{~d}, J=6.1 \mathrm{~Hz}, 1 \mathrm{H}), 1.71-1.61(\mathrm{~m}, 1 \mathrm{H}), 1.17(\mathrm{~d}, J=6.4 \mathrm{~Hz}, 3 \mathrm{H}), 1.02(\mathrm{~d}, J=6.6$ $\mathrm{Hz}, 3 \mathrm{H}), 0.89(\mathrm{~d}, J=6.8 \mathrm{~Hz}, 3 \mathrm{H})$. 


\section{( \pm )-anti-4-methylpentane-2,3-diol (SM 18b)}<smiles>CC=CC(C)C</smiles>

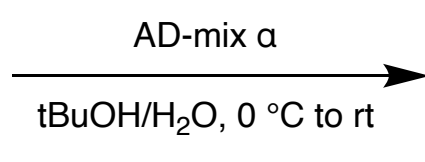<smiles>CC(C)C(O)C(C)O</smiles>

To a $50 \mathrm{~mL}$ round-bottom flask with stir bar was added 1:1 water/tert-butanol $(20 \mathrm{~mL}, 0.1 \mathrm{M})$, AD-mix a (2.8 g), and methanesulfonamide (190 mg, 1 equiv.). The resulting orange solution was cooled to $0{ }^{\circ} \mathrm{C}$ in an ice bath and cis-3-hexene was added via syringe $(0.25 \mathrm{~mL}, 2 \mathrm{mmol}, 1$ equiv.). The resulting orange slurry was stirred vigorously overnight at room temperature. Upon reaction completion, $\mathrm{Na}_{2} \mathrm{SO}_{3}(3 \mathrm{~g})$ was added, and the mixture was stirred for $30 \mathrm{~m} .20 \mathrm{~mL}$ EtOAc were added, the organic and aqueous layers were separated, and the aqueous layer was extracted $3 \times$ with $10 \mathrm{~mL}$ portions of EtOAc. The organic layers were combined, washed sequentially with $1 \mathrm{M}$ aqueous $\mathrm{NaOH}$ and brine, dried over $\mathrm{MgSO}$, and concentrated under vacuum. Purification by flash column chromatography (silica gel, 1:1 EtOAc/hexanes) and subsequent removal of solvent provided the title compound as a colorless oil (130 mg, $1.1 \mathrm{mmol}, 55 \%$ yield). ${ }^{1} \mathrm{H}$ NMR shifts were consistent with those reported in the literature. ${ }^{14}$

( \pm )-1-(trans-3,4-dihydroxypiperidin-1-yl)-3-(4,5-diphenyloxazol-2-yl)propan-1-one (SM 21)<smiles>COC(=O)[C@H](C)C[NH+]1CC[C@@H](O)[C@H](O)C1</smiles><smiles>O=C(O)CCc1nc(-c2ccccc2)c(-c2ccccc2)o1</smiles>

( \pm -trans-3,4-piperidinediol hydrochloride was prepared from $( \pm)-N$-Boc-trans-piperidine-3,4diol (SM 7) according to a literature procedure. ${ }^{3}$

To an oven-dried $25 \mathrm{~mL}$ round-bottom flask with stir bar was added oxaprozin $(293.3 \mathrm{mg}, 1 \mathrm{mmol}$, 1 equiv.), $1.2 \mathrm{~mL}$ dry DCM, and $4.8 \mathrm{~mL}$ dry DMF. To the resulting solution was added HATU (570.3 mg, $1.5 \mathrm{mmol}, 1.5$ equiv.), and the solution was stirred for 20 minutes at room temperature. 
Then, ( \pm )-trans-3,4-piperidinediol hydrochloride (184.3 mg, $1.2 \mathrm{mmol}, 1.2$ equiv.) and DIPEA (0.7 mL, 4 mmol, 4 equiv.) were added. The resulting yellow solution was stirred for 4 hours at room temperature. The reaction mixture was diluted with $100 \mathrm{~mL}$ in a separatory funnel and washed with $3 \times 50 \mathrm{~mL} 10 \%$ aqueous $\mathrm{LiCl}$, then with $50 \mathrm{~mL}$ brine. The organic layer was then dried with anhydrous $\mathrm{MgSO}_{4}$, filtered, and solvent was removed under vacuum. Subsequent purification by column chromatography (silica, $0-10 \% \mathrm{MeOH} / \mathrm{DCM}$ gradient) and removal of solvent under vacuum yielded the title compound as a light-brown solid (325 mg, $0.83 \mathrm{mmol}, 83 \%$ yield).

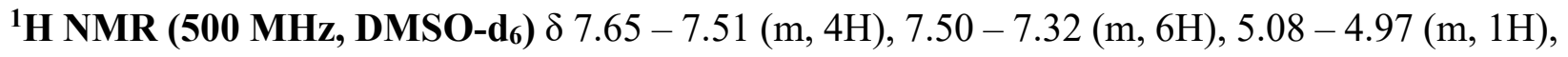
$4.90(\mathrm{~m}, 1 \mathrm{H}), 4.14-2.66(\mathrm{~m}, 10 \mathrm{H}), 1.89-1.74(\mathrm{~m}, 1 \mathrm{H}), 1.42-1.18(\mathrm{~m}, 1 \mathrm{H})$. Mixture of rotamers as determined by high-temperature NMR.

${ }^{13}$ C NMR (126 MHz, DMSO-d6) $\delta$ 169.22, 168.98, 163.10, 163.05, 144.42, 134.35, 132.11, $128.99,128.78,128.69,128.52,128.16,127.42,126.34,71.34,70.46,69.84,69.58,48.08,45.46$, $42.46,38.19,31.81,29.86,28.99,28.89,23.29,23.26$. Mixture of rotamers as determined by hightemperature ${ }^{1} \mathrm{H}$ NMR.

IR (film) $v_{\max } 3340,2923,1618,1442,1215,1058,962,762,692,673$

HRMS (EI-TOF) $m / z$ calcd. for $\mathrm{C}_{23} \mathrm{H}_{25} \mathrm{~N}_{2} \mathrm{O}_{4}{ }^{+}\left([\mathrm{M}+\mathrm{H}]^{+}\right) 393.18088$, found 393.18192 .

\section{(土)-trans-3-hydroxy-4-(hydroxymethyl)tetrahydrofuran (SM 25)}
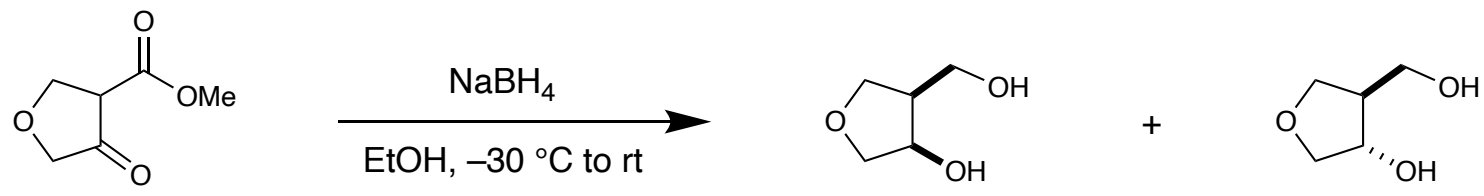

The title compound was prepared by a modification of a literature procedure. ${ }^{2}$

To a $50 \mathrm{~mL}$ round-bottom flask with stir bar was added ethanol $(12.5 \mathrm{~mL})$, then the flask was cooled to $-30{ }^{\circ} \mathrm{C}$ in a dry ice/acetone bath monitored with a low-temperature thermometer. Sodium borohydride (1.89 g, $50 \mathrm{mmol}, 5$ equiv.) was added, followed by dropwise addition of a solution of methyl 3-oxotetrahydrofuran-4-carboxylate in ethanol (1.44 g, $10 \mathrm{mmol}, 1$ equiv. in $2.5 \mathrm{~mL}$ $\mathrm{EtOH})$. The solution was stirred with temperature maintained at $-30{ }^{\circ} \mathrm{C}$ for 30 minutes, then 
allowed to warm to room temperature and stirred for 18 hours. The reaction was then quenched to acidity with $1 \mathrm{M}$ aqueous $\mathrm{HCl}$ and all solvents were removed under vacuum. The solid residue was then triturated with $3 \times 50 \mathrm{~mL}$ portions of $4: 1 \mathrm{DCM} / \mathrm{MeOH}$ which were combined and evaporated. Flash column chromatography of the residue (silica, 5-10\% MeOH/DCM then 10\% $\mathrm{MeOH} / \mathrm{DCM}$ ) provided the title compound as a thick, clear oil (498 mg, $4.2 \mathrm{mmol}, 42 \%$ yield). A small amount of presumed cis isomer was also formed, but was separated during column chromatography and not characterized at this stage.

${ }^{1}$ H NMR (500 MHz, CDCl 3$) \delta 4.33(\mathrm{dt}, J=5.6,3.0 \mathrm{~Hz}, 1 \mathrm{H}), 4.09(\mathrm{dd}, J=9.0,7.3 \mathrm{~Hz}, 1 \mathrm{H}), 3.93$ $(\mathrm{dd}, J=9.8,5.1 \mathrm{~Hz}, 1 \mathrm{H}), 3.75-3.67(\mathrm{~m}, 2 \mathrm{H}), 3.62(\mathrm{dd}, J=10.5,7.8 \mathrm{~Hz}, 1 \mathrm{H}), 3.57$ (dd, $J=9.0$, $5.2 \mathrm{~Hz}, 1 \mathrm{H}), 2.47-2.33(\mathrm{~m}, 1 \mathrm{H})$.

${ }^{13}$ C NMR (126 MHz, CDCl $) \delta$ 75.02, 74.88, 69.55, 63.16, 51.05.

IR (film) $v_{\max } 3328,2872,1330,1068,1036,999,904$

HRMS (EI-TOF) $m / z$ calcd. for $\mathrm{C}_{5} \mathrm{H}_{10} \mathrm{O}_{3}{ }^{+}\left([\mathrm{M}]^{+}\right) 118.06245$, found 118.06240

\section{(1S,2S)-2-(hydroxymethyl)cyclohexanol (SM 26)}<smiles>CCOC(=O)C1CCCCC1=O</smiles><smiles>CCOC(=O)C1CCCCC1O</smiles><smiles>OC[C@H]1CCCC[C@H]1O</smiles>

$(+)$

\section{Step 1: Asymmetric reduction of ethyl 2-oxo-cyclohexanecarboxylate}

The reduction was accomplished with an adapted literature procedure. ${ }^{15}$ To a $1000 \mathrm{~mL}$ roundbottom flask with stir bar was added $450 \mathrm{~mL}$ pH $810 \mathrm{mM}$ aqueous phosphate buffer $(0.03 \mathrm{M})$, one packet of baker's yeast (7.5 g, Fleischmann's ActiveDry brand), and glucose ( $3 \mathrm{~g}, 16.7 \mathrm{mmol}$, 1.1 equiv.). The resulting murky suspension was heated to $30{ }^{\circ} \mathrm{C}$ and stirred rapidly. After 30 minutes, ethyl 2-oxo-cyclohexanecarboxylate (2.4 g, $15 \mathrm{mmol}, 1$ equiv.) was added dropwise, and the solution was maintained at $30{ }^{\circ} \mathrm{C}$ with continued stirring. After 18 hours, the aqueous suspension was filtered through a pad of Celite to remove suspended yeast cells, and the resulting clear solution was extracted with $3 \times 300 \mathrm{~mL}$ portions of EtOAc. The organic layers were 
combined, dried with anhydrous $\mathrm{MgSO}_{4}$, filtered, and solvent was removed. Purification by flash column chromatography (silica, 0-25\% EtOAc/hexane gradient followed by $100 \%$ EtOAc) and subsequent removal of solvent yielded cis-ethyl 2-hydroxy-cyclohexanecarboxylate as a clear oil (739 mg, $4.3 \mathrm{mmol}, 29 \%$ yield, absolute configuration not determined at this stage). ${ }^{1} \mathrm{H}$ NMR shifts were consistent with those reported in the literature. ${ }^{16}$

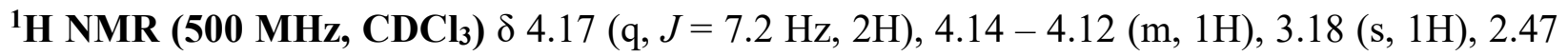
$(\mathrm{ddd}, J=11.3,3.9,2.6 \mathrm{~Hz}, 1 \mathrm{H}), 1.96-1.81(\mathrm{~m}, 2 \mathrm{H}), 1.78-1.63(\mathrm{~m}, 3 \mathrm{H}), 1.54-1.39(\mathrm{~m}, 2 \mathrm{H})$, $1.39-1.29(\mathrm{~m}, 1 \mathrm{H}), 1.27(\mathrm{t}, J=7.1 \mathrm{~Hz}, 3 \mathrm{H})$.

\section{Step 2: Reduction of ethyl 2-hydroxy-cyclohexanecarboxylate}

To a flame-dried $100 \mathrm{~mL}$ 2-neck round-bottom flask with stir bar and reflux condenser under nitrogen was added ethyl 2-hydroxy-cyclohexanecarboxylate (689 mg, $4 \mathrm{mmol}, 1$ equiv.) and tetrahydrofuran $(14 \mathrm{~mL}, 0.3 \mathrm{M})$. The solution was cooled to $0{ }^{\circ} \mathrm{C}$ with a water/ice bath, then $\mathrm{LiAlH}_{4}$ (6.5 mmol, $6.5 \mathrm{~mL} 1 \mathrm{M}$ solution in THF, 1.63 equiv.) was added dropwise with evolution of gas. The solution was stirred at $0{ }^{\circ} \mathrm{C}$ for a further 15 minutes, then removed from the ice bath and heated to reflux for 17 hours. The reaction was again cooled to $0{ }^{\circ} \mathrm{C}$ in a water/ice bath and quenched with the Fieser workup: $0.35 \mathrm{~mL}$ water was added dropwise, followed by $0.35 \mathrm{~mL} 4 \mathrm{M}$ $\mathrm{NaOH}$ and an additional $1 \mathrm{~mL}$ water. The flask was removed from the ice bath and stirred for 15 minutes, then $\mathrm{MgSO}_{4}$ was added and the solution was stirred for an additional 15 minutes, then filtered and solvent was removed under vacuum. Flash column chromatography (silica, 0-10\% $\mathrm{MeOH} / \mathrm{DCM}$ gradient followed by $10 \% \mathrm{MeOH} / \mathrm{DCM}$ ) and removal of solvent under vacuum provided the title compound as a clear, thick oil (521 mg, $3.5 \mathrm{mmol}, 87 \%$ yield, 93\% ee). ${ }^{1} \mathrm{H} \mathrm{NMR}$ shifts and optical rotation value were consistent with those reported in the literature. ${ }^{16}$ Enantiomeric excess was determined by chiral HPLC of the bis-benzoyl protected diol (Chiralcel OJ, IPA/hexanes).

${ }^{1}$ H NMR (500 MHz, $\left.\mathbf{C D C l}_{3}\right) \delta 4.21-4.10(\mathrm{~m}, 1 \mathrm{H}), 3.82-3.68(\mathrm{~m}, 2 \mathrm{H}), 1.78(\mathrm{dq}, J=13.4,4.1$ $\mathrm{Hz}, 1 \mathrm{H}), 1.75-1.57(\mathrm{~m}, 4 \mathrm{H}), 1.57-1.36(\mathrm{~m}, 3 \mathrm{H}), 1.34-1.22(\mathrm{~m}, 1 \mathrm{H})$.

Optical rotation: $[\alpha]_{\mathrm{D}}=+31.4^{\circ} \pm 0.1^{\circ}(\mathrm{c}=1.01, \mathrm{EtOH})$ 


\section{Chiral HPLC:}

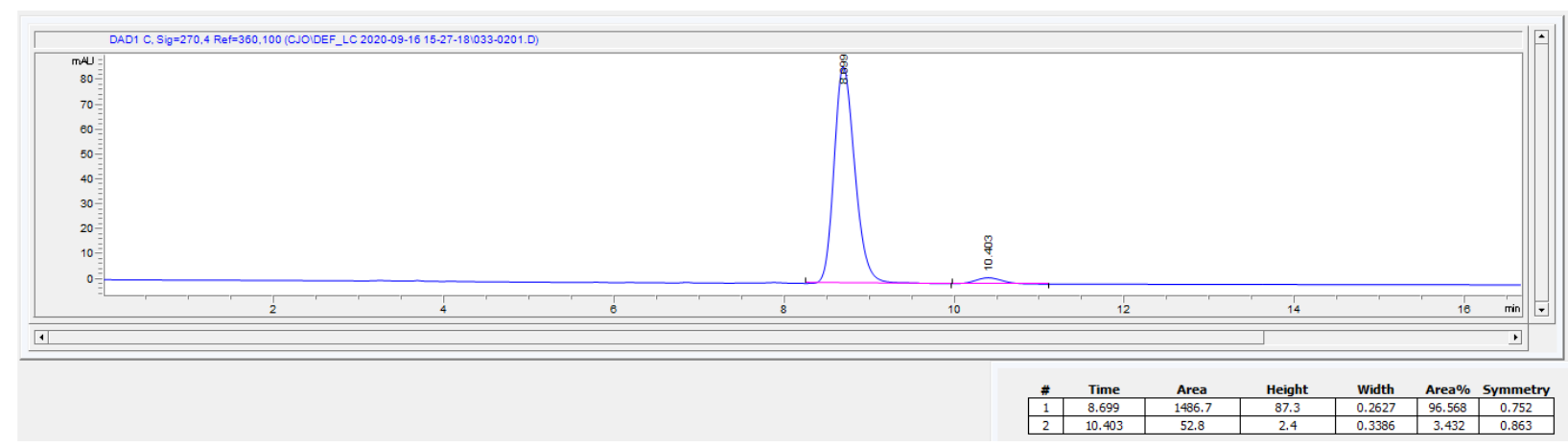

( \pm )- $N$-Boc-cis-3-hydroxy-4-(hydroxymethyl)-piperidine (SM 27) and ( \pm )- $N$-Boc-trans-3hydroxy-4-(hydroxymethyl)-piperidine (27)<smiles>CCOC(=O)C1CCN(C(C)(C)C)CC1=O</smiles>

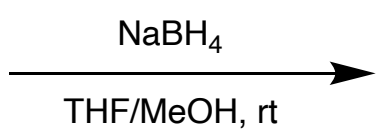<smiles>CC(C)(C)ON1CCC(CO)C(O)C1</smiles><smiles></smiles>

To a $100 \mathrm{~mL}$ round-bottom flask with stir bar was added ethyl $N$-Boc-3-oxopiperidine-4carboxylate (2.71 g, $10 \mathrm{mmol}, 1$ equiv.) and 2:1 tetrahydrofuran/methanol (45 mL, $0.22 \mathrm{M})$. The resulting solution was cooled to $0{ }^{\circ} \mathrm{C}$ with a water-ice bath, then sodium borohydride $(946 \mathrm{mg}, 25$ mmol, 2.5 equiv.) was added. The flask was allowed to warm to room temperature, stirred for 15 minutes, then an additional portion of sodium borohydride was added (946 mg, $25 \mathrm{mmol}, 2.5$ equiv.). The solution was stirred for a further 1 hour, then quenched by addition of $50 \mathrm{~mL}$ saturated aqueous $\mathrm{NH}_{4} \mathrm{Cl}$ solution. Organic and aqueous layers were separated, and the aqueous layer was extracted $5 \times$ with EtOAc. Organic layers were combined, dried over anhydrous $\mathrm{MgSO}_{4}$, filtered and solvent was removed under vacuum. Flash column chromatography (silica, dry load, 1\% $\mathrm{MeOH} / \mathrm{DCM}$ ) followed by removal of solvent under vacuum provided the title compounds as clear, thick oils (trans isomer: $498 \mathrm{mg}, 2.2 \mathrm{mmol}, 22 \%$ yield as earlier-eluting peak, cis isomer: $603 \mathrm{mg}, 2.6 \mathrm{mmol}, 26 \%$ yield, later-eluting peak). ${ }^{1} \mathrm{H}$ NMR shifts were consistent with those reported in the literature. ${ }^{17}$ 
( \pm )-N-Boc-cis-3-hydroxy-4-(hydroxymethyl)-piperidine: ${ }^{1} \mathrm{H}$ NMR (400 MHz, $\left.\mathrm{CD}_{3} \mathrm{OD}\right) \delta 4.17$ - 4.00 (m, 3H), 3.91 (s, 1H), 3.62 (dd, $J=10.7,7.0 \mathrm{~Hz}, 1 \mathrm{H}), 3.48$ (dd, $J=10.7,6.2 \mathrm{~Hz}, 1 \mathrm{H}), 2.87$ (s, $1 \mathrm{H}), 2.76(\mathrm{~s}, 1 \mathrm{H}), 1.74-1.63(\mathrm{~m}, 1 \mathrm{H}), 1.63-1.52(\mathrm{~m}, 1 \mathrm{H}), 1.48-1.40(\mathrm{~m}, 10 \mathrm{H})$.

( \pm )- $N$-Boc-trans-3-hydroxy-4-(hydroxymethyl)-piperidine: ${ }^{1} \mathrm{H}$ NMR $\left(500 \mathrm{MHz}, \mathrm{CDCl}_{3}\right) \delta$ $4.22(\mathrm{~s}, 1 \mathrm{H}), 4.16-4.01(\mathrm{~m}, 1 \mathrm{H}), 3.78(\mathrm{~s}, 1 \mathrm{H}), 3.73-3.66(\mathrm{~m}, 1 \mathrm{H}), 3.60-3.50(\mathrm{~m}, 1 \mathrm{H}), 2.66(\mathrm{~s}$, $1 \mathrm{H}), 2.54(\mathrm{~d}, J=11.6 \mathrm{~Hz}, 1 \mathrm{H}), 1.77-1.64(\mathrm{~m}, 1 \mathrm{H}), 1.63-1.52(\mathrm{~m}, 1 \mathrm{H}), 1.45(\mathrm{~s}, 9 \mathrm{H}), 1.14(\mathrm{qd}, J$ $=12.7,4.5 \mathrm{~Hz}, 1 \mathrm{H})$. 


\section{4) Standard reaction setup}

For the epimerization reactions, the reaction mixture is irradiated in a PennOC Integrated Photoreactor $^{18}$ for the stated duration with the following settings: $100 \%$ light intensity, maximum fan speed, $400 \mathrm{rpm}$ stir rate. Alternately, the reactions can be performed with irradiation from a Kessil PR160 $40 \mathrm{~W} 390 \mathrm{~nm}$ lamp from a distance of $6 \mathrm{~cm}$ with stirring and fans used to maintain a reaction temperature of $<30{ }^{\circ} \mathrm{C}$. The reaction vials, lamps, stir plates, and fans are all placed behind a black hardboard or amber acrylic box for the duration of the reaction to avoid undesired UV light leakage. Reactions conducted with the Integrated Photoreactor typically require shorter reaction times than those conducted with the Kessil lamps (see Supplementary Table 1).

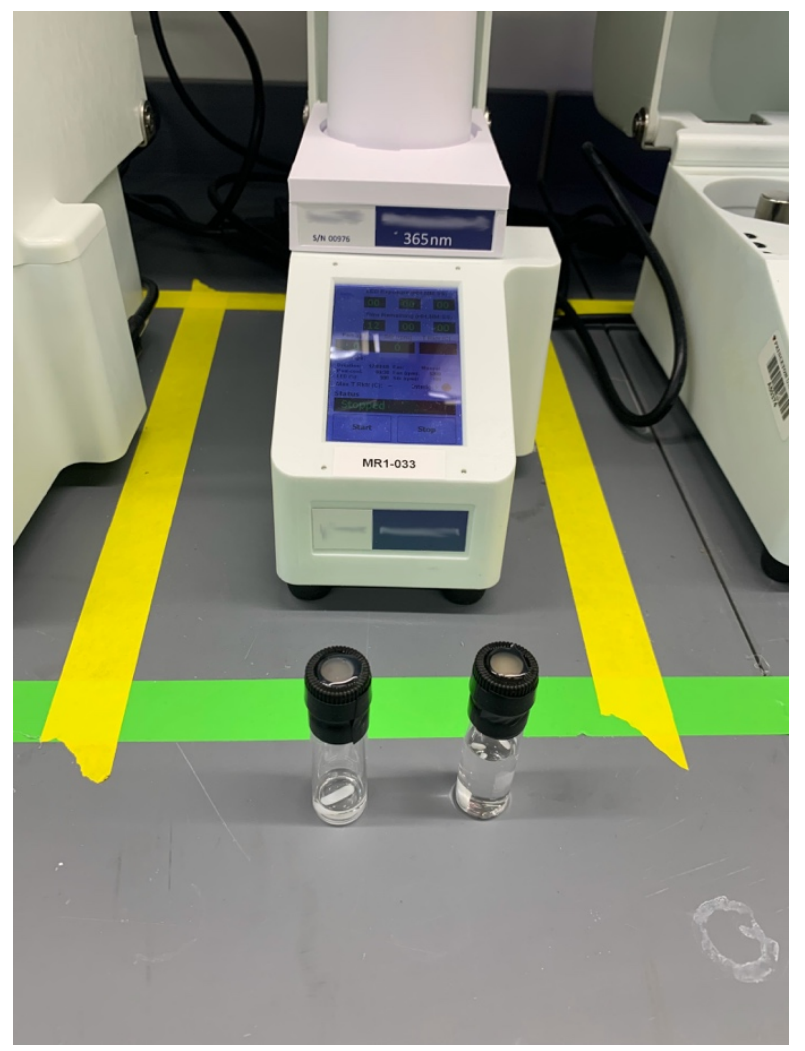

Supplementary Figure S1. Reaction vials for $0.1 \mathrm{mmol}$ scale (left) and $0.5 \mathrm{mmol}$ scale (right) 
Supporting Information

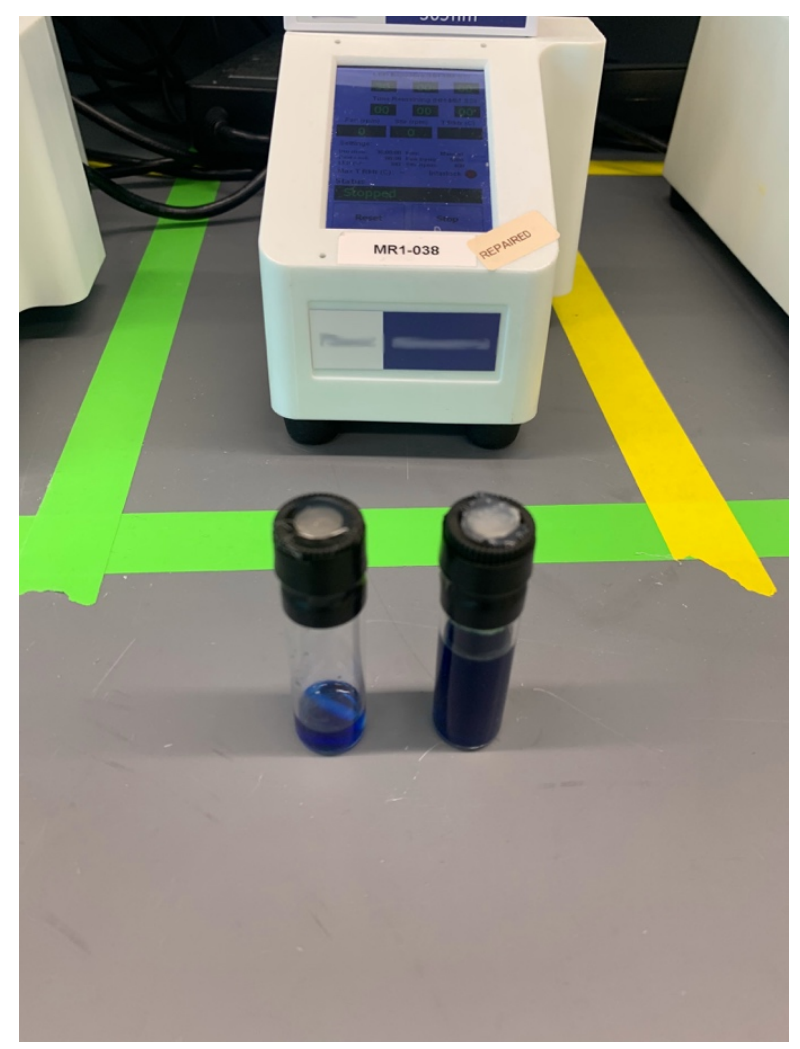

Supplementary Figure S2. Reaction vials after reaction completion 
Supporting Information

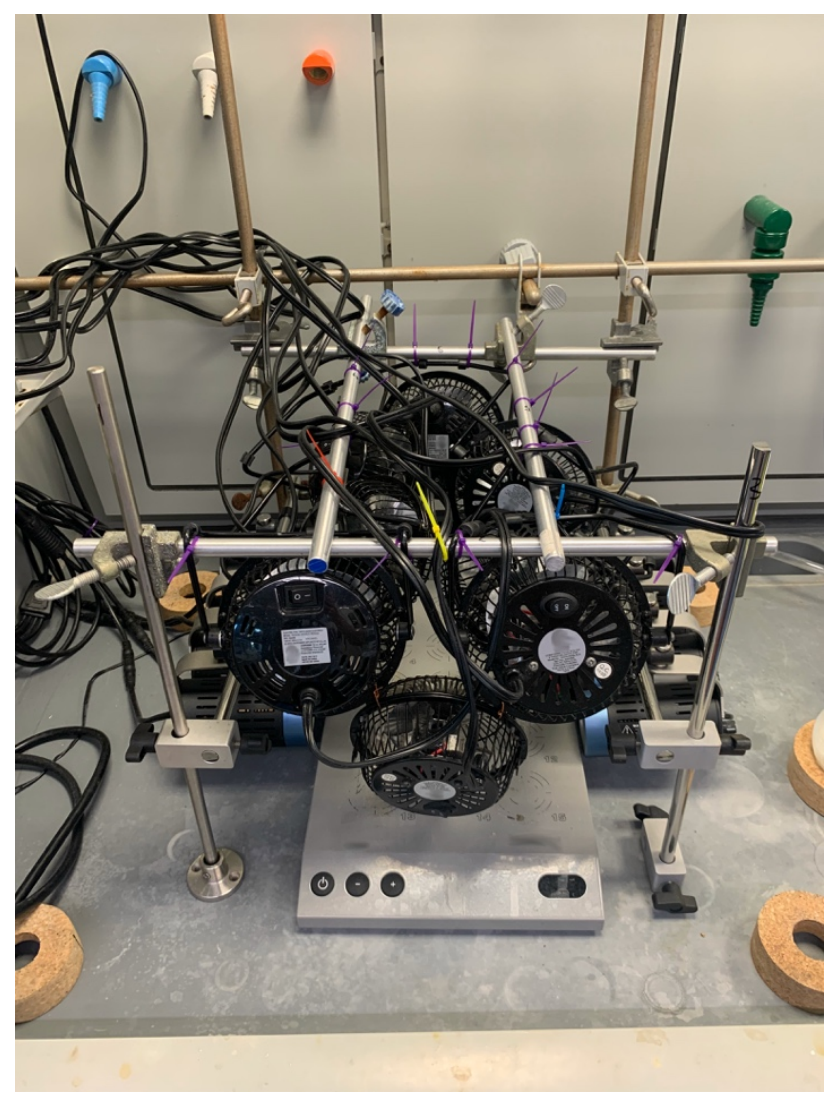

Supplementary Figure S3. Alternative reaction setup with Kessil lamps 
Supporting Information

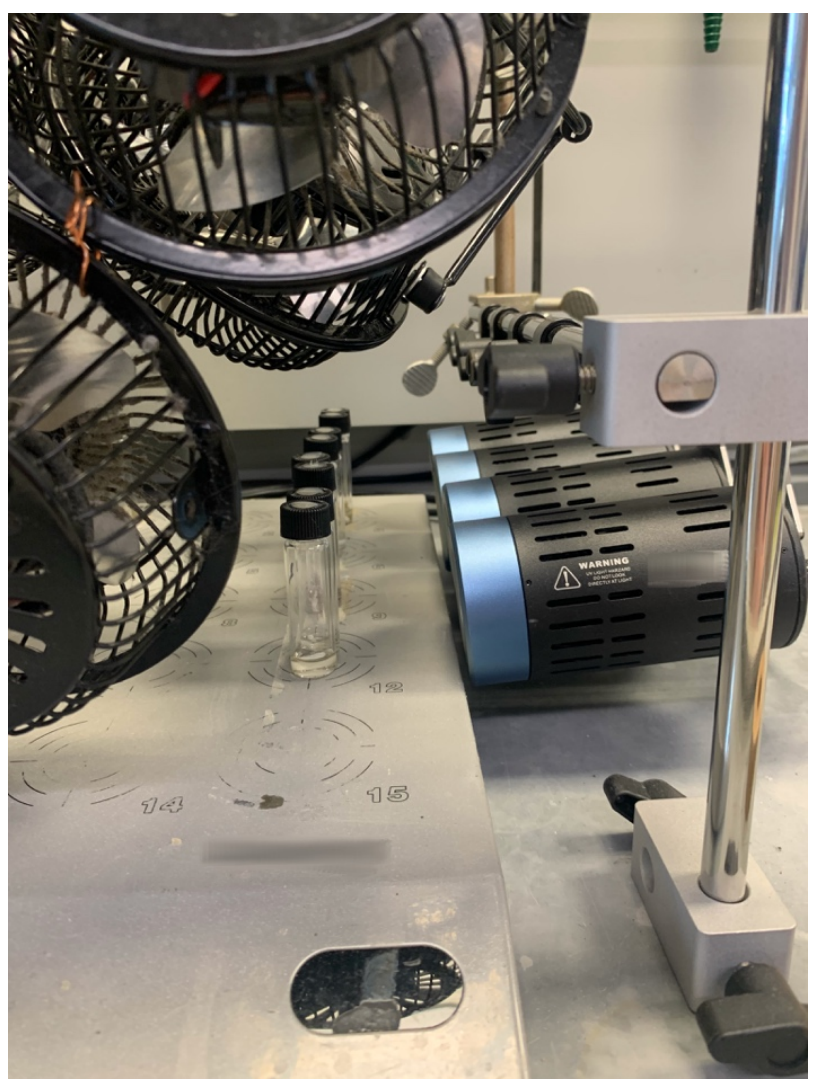

Supplementary Figure S4. Closeup view of alternative reaction setup 
Supporting Information

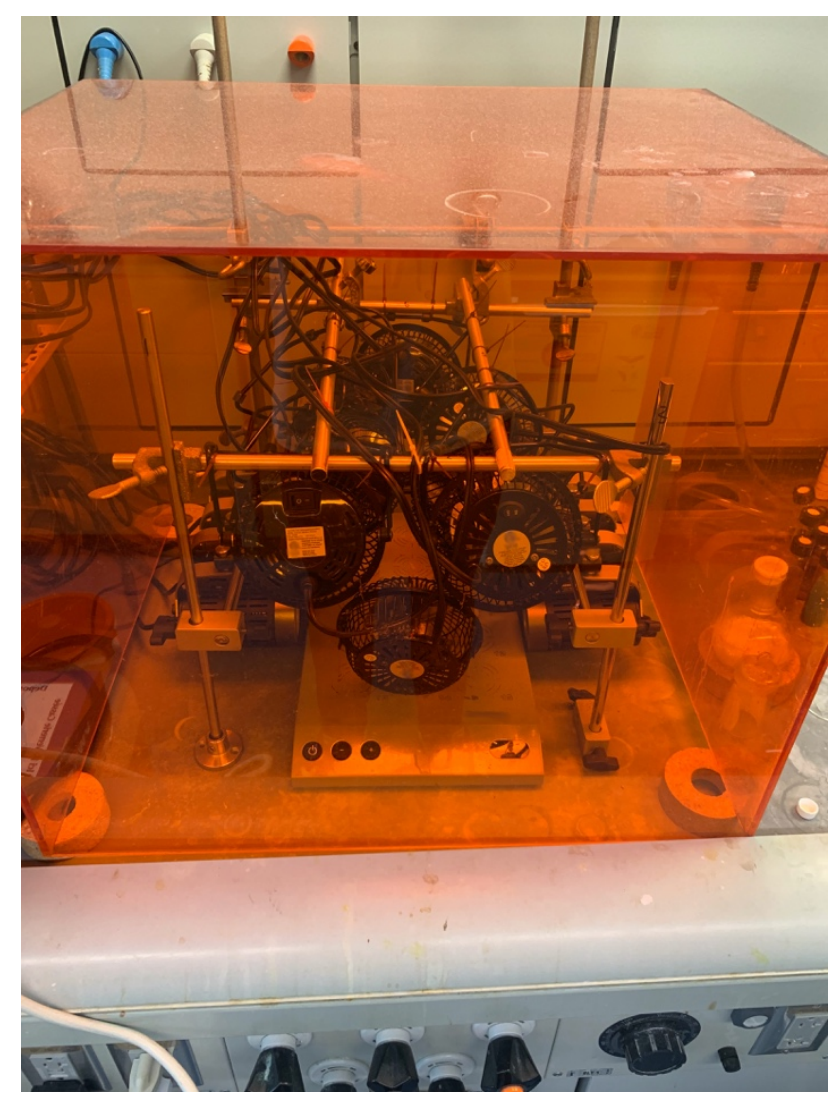

Supplementary Figure S5. UV light-shielding amber acrylic box used during reactions 


\section{5) Optimization and control experiments}

\section{Example procedure for optimization:}

To an $8 \mathrm{~mL}$ screw-cap vial equipped with a septum and stir bar was added trans-1,2cyclohexanediol (11.6 mg, $0.1 \mathrm{mmol}, 1$ equiv.), methylboronic acid (7.5 mg, $0.125 \mathrm{mmol}, 1.25$ equiv.), diphenyl disulfide (10.9 $\mathrm{mg}, 0.05 \mathrm{mmol}, 50 \mathrm{~mol} \%$ ), and tetrabutylphosphonium decatungstate $(1.7 \mathrm{mg}, 0.5 \mu \mathrm{mol}, 0.5 \mathrm{~mol} \%)$, followed by dry acetonitrile $(1.0 \mathrm{~mL})$ for a reaction concentration of $0.1 \mathrm{M}$ relative to cyclohexanediol. The resulting mixture was stirred or sonicated briefly to homogeneity, then sparged for 15 minutes with nitrogen with vials placed in an ice bath to prevent solvent evaporation. After sparging, vials were sealed using a hot glue gun and electrical tape (see Supplementary Figure S1 above), then irradiated with Kessil PR160 40 W 390 nm LEDs for 18 hours as described in the standard reaction setup. After 18 hours, vials were removed from the stir plate, opened to air, mesitylene (12.0 mg, $14 \mu \mathrm{L}, 1.0$ equiv.) was added via microsyringe and a $0.1 \mathrm{~mL}$ aliquot was removed and analyzed by ${ }^{1} \mathrm{H}$ NMR.

The above procedure was modified as necessary to screen the desired variables. If two or more components were held constant, a single stock solution in acetonitrile was prepared with those components. 


\section{Supplementary Table S1. Optimization of epimerization reaction conditions}

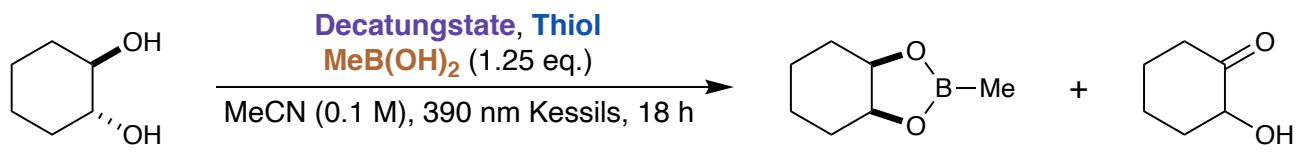

$0.1 \mathrm{mmol}$

\begin{tabular}{ccccccc} 
Entry & Decatungstate & Thiol & cis diol & trans diol/esters & cis ester & hydroxyketone \\
\hline 1 & $\left(\mathrm{Bu}_{4} \mathrm{~N}\right)_{4} \mathrm{~W}_{10} \mathrm{O}_{32}(1 \mathrm{~mol} \%)$ & $\mathrm{PhSH}(20 \mathrm{~mol} \%)$ & $0 \%$ & $61 \%$ & $34 \%$ & $5 \%$ \\
2 & $\left(\mathrm{Bu}_{4} \mathrm{~N}\right)_{4} \mathrm{~W}_{10} \mathrm{O}_{32}(1 \mathrm{~mol} \%)$ & $(\mathrm{PhS})_{2}(50 \mathrm{~mol} \%)$ & $0 \%$ & $9 \%$ & $71 \%$ & $5 \%$ \\
3 & $\left(\mathrm{Bu}_{4} \mathrm{P}\right)_{4} \mathrm{~W}_{10} \mathrm{O}_{32}(0.5 \mathrm{~mol} \%)$ & $(\mathrm{PhS})_{2}(50 \mathrm{~mol} \%)$ & $0 \%$ & $4 \%$ & $70 \%$ & $4 \%$ \\
$4^{*}$ & $\left(\mathrm{Bu}_{4} \mathrm{P}\right)_{4} \mathrm{~W}_{10} \mathrm{O}_{32}(0.5 \mathrm{~mol} \%)$ & $(\mathrm{PhS})_{2}(50 \mathrm{~mol} \%)$ & $0 \%$ & $5 \%$ & $74 \%$ & $5 \%$ \\
\multicolumn{5}{c}{$* 3 \mathrm{~h}$ irradiation with PennOptical Integrated Photoreactor }
\end{tabular}

Under optimized conditions, $80-85 \%$ of the initial starting diol was accounted for by NMR assay. As such, a thorough investigation of the missing material was conducted. No side products other than a-hydroxycyclohexanone were detectable by mass spectrometry, ${ }^{1} \mathrm{H}$ or ${ }^{13} \mathrm{C} \mathrm{NMR}$, and, likewise, no side products could be isolated from reaction mixtures. A spin-center shift pathway was considered, as additive-promoted redox isomerizations of 1,2-diols to generate ketones are known to occur under photochemical HAT conditions. ${ }^{19}$ However, no cyclohexanone was detected in the crude reaction mixture nor isolated, nor were keto-deoxy products detected or isolated for several trans diol substrates.

Subjection of a-hydroxycyclohexanone to the epimerization conditions led to substantial consumption of the material, and formation of a complex mixture which could not be effectively isolated or characterized. Consumption of the a-hydroxyketone was accelerated by the presence of boronic acid, but could still occur in its absence (i.e. irradiation in the presence of only decatungstate and diphenyl disulfide). The ${ }^{1} \mathrm{H}$ spectrum of the mixture had several features in common with near-baseline features observed in crude ${ }^{1} \mathrm{H}$ spectra of the diol epimerization reaction.

Based on this evidence, we hypothesize that the missing material consists primarily of compounds derived from further oxidation or HAT from the a-hydroxyketone side product. The hydroxyketone is likely generated by oxidation of an a-oxy radical by ground-state decatungstate. ${ }^{20}$ 


\section{Supplementary Table S2. Control reactions}<smiles>O[C@H]1CCCC[C@H]1O</smiles>

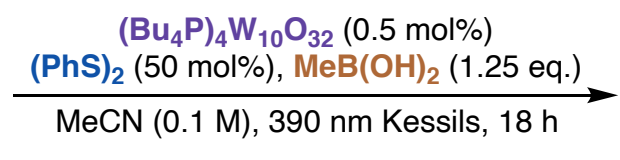<smiles>CB1OC2CCCCC2O1</smiles><smiles>O=C1CCCCC1O</smiles>

$0.1 \mathrm{mmol}$

\begin{tabular}{cccccc} 
Entry & Deviation & cis diol & trans diol/esters & cis ester & hydroxyketone \\
\hline 1 & none & $0 \%$ & $4 \%$ & $70 \%$ & $4 \%$ \\
2 & no decatungstate & $0 \%$ & $100 \%$ & $0 \%$ & $0 \%$ \\
3 & no $(\mathrm{PhS})_{2}$ & $0 \%$ & $80 \%$ & $13 \%$ & $6 \%$ \\
4 & no $\mathrm{MeB}(\mathrm{OH})_{2}$ & $25 \%$ & $47 \%$ & - & $20 \%$ \\
5 & no light & $0 \%$ & $100 \%$ & $0 \%$ & $0 \%$
\end{tabular}

\section{Supplementary Table S3. Convergence of diol isomers in boronic-acid-free epimerization}

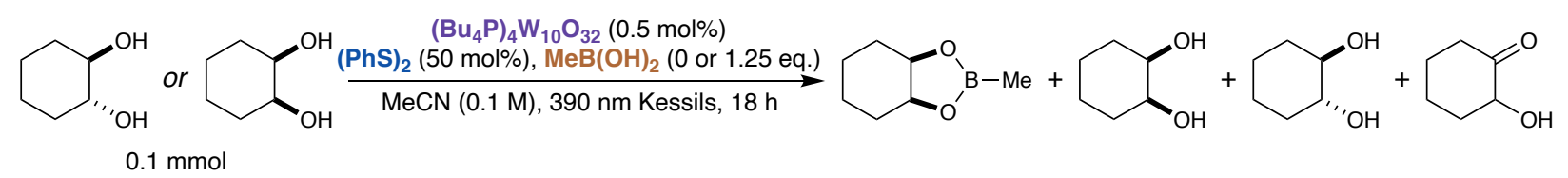

\begin{tabular}{cccccc} 
Boronic acid? & Starting diol & cis diol & trans diol/esters & cis ester & hydroxyketone \\
\hline Yes & trans & $0 \%$ & $4 \%$ & $70 \%$ & $4 \%$ \\
Yes & cis & $0 \%$ & $2 \%$ & $82 \%$ & $2 \%$ \\
No & trans & $25 \%$ & $46 \%$ & - & $25 \%$ \\
No & cis & $27 \%$ & $45 \%$ & - & $23 \%$
\end{tabular}




\section{Supplementary Table S4: Evaluation of boron chelators for the epimerization}

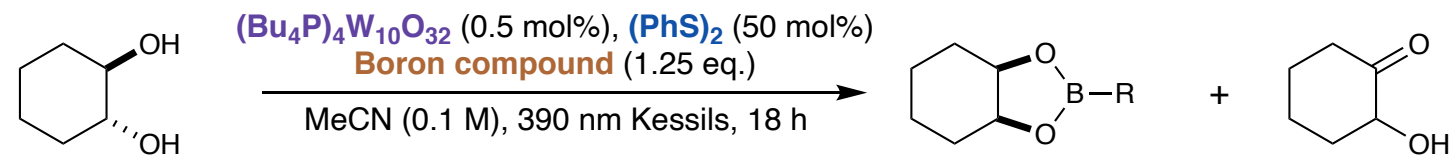

$0.1 \mathrm{mmol}$

\begin{tabular}{cccccc} 
Entry & Boron & cis diol & trans diol/esters & cis ester & hydroxyketone \\
\hline 1 & $\mathrm{MeB}(\mathrm{OH})_{2}$ & $0 \%$ & $4 \%$ & $70 \%$ & $4 \%$ \\
2 & $\mathrm{cPrB}(\mathrm{OH})_{2}$ & $0 \%$ & $7 \%$ & $68 \%$ & $10 \%$ \\
3 & $\mathrm{PhB}(\mathrm{OH})_{2}$ & $0 \%$ & $12 \%$ & $64 \%$ & $4 \%$ \\
4 & $(4-t \mathrm{Bu}) \mathrm{C}_{6} \mathrm{H}_{4} \mathrm{~B}(\mathrm{OH})_{2}$ & $0 \%$ & $15 \%$ & $51 \%$ & $7 \%$ \\
5 & $(4-\mathrm{MeO}) \mathrm{C}_{6} \mathrm{H}_{4} \mathrm{~B}(\mathrm{OH})_{2}$ & $0 \%$ & $9 \%$ & $65 \%$ & $10 \%$ \\
6 & $(2,4,6-\mathrm{Me}) \mathrm{C}_{6} \mathrm{H}_{2} \mathrm{~B}(\mathrm{OH})_{2}$ & $0 \%$ & $19 \%$ & $49 \%$ & $17 \%$ \\
7 & $(4-\mathrm{CF})_{3} \mathrm{C}_{6} \mathrm{H}_{4} \mathrm{~B}(\mathrm{OH})_{2}$ & $0 \%$ & $5 \%$ & $61 \%$ & $10 \%$ \\
8 & $(3,5-\mathrm{dCF})_{3} \mathrm{C}_{6} \mathrm{H}_{3} \mathrm{~B}(\mathrm{OH})_{2}$ & $0 \%$ & $23 \%$ & $34 \%$ & $14 \%$ \\
9 & $(\mathrm{MeBO})_{3}{ }^{*}$ & $0 \%$ & $10 \%$ & $59 \%$ & $8 \%$ \\
10 & $\mathrm{Ph}_{2} \mathrm{BOH}$ & $0 \%$ & $30 \%$ & $33 \%$ & $0 \%$ \\
11 & $\mathrm{~B}_{(\mathrm{OMe})_{3}}$ & $0 \%$ & $16 \%$ & $53 \%$ & $17 \%$ \\
12 & $\mathrm{~B}(\mathrm{OH})_{3}$ & $0 \%$ & $22 \%$ & $42 \%$ & $21 \%$
\end{tabular}

${ }^{\star} 0.42$ eq. boroxine (1.25 eq. boron) 
Supplementary Table S5: Evaluation of disulfides for the epimerization

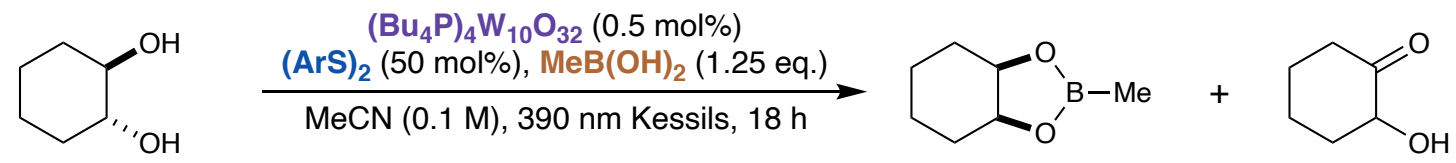

$0.1 \mathrm{mmol}$

\begin{tabular}{cccccc} 
Entry & Disulfide & cis diol & trans diol/esters & cis ester & hydroxyketone \\
\hline 1 & $(\mathrm{PhS})_{2}$ & $0 \%$ & $4 \%$ & $\mathbf{7 0 \%}$ & $4 \%$ \\
2 & $\left(4-\mathrm{MeC}_{6} \mathrm{H}_{4} \mathrm{~S}\right)_{2}$ & $0 \%$ & $4 \%$ & $66 \%$ & $2 \%$ \\
3 & $\left(2,4,6-\mathrm{Me}_{3} \mathrm{C}_{6} \mathrm{H}_{2} \mathrm{~S}\right)_{2}$ & $0 \%$ & $5 \%$ & $60 \%$ & $3 \%$ \\
4 & $\left(2,4,6-\mathrm{PrC}_{6} \mathrm{H}_{2} \mathrm{~S}\right)_{2}$ & $0 \%$ & $3 \%$ & $57 \%$ & $0 \%$ \\
5 & $(1-\mathrm{naphthylS})_{2}$ & $0 \%$ & $39 \%$ & $\mathbf{4 1 \%}$ & $3 \%$ \\
6 & $\left(4-(\mathrm{MeO}) \mathrm{C}_{6} \mathrm{H}_{4} \mathrm{~S}\right)_{2}$ & $7 \%$ & $42 \%$ & $\mathbf{2 6 \%}$ & $8 \%$ \\
7 & $\left(2,4-\mathrm{F}_{2} \mathrm{C}_{6} \mathrm{H}_{3} \mathrm{~S}\right)_{2}$ & $0 \%$ & $21 \%$ & $\mathbf{4 7 \%}$ & $5 \%$ \\
8 & $\left(2,6-\mathrm{Cl}_{2} \mathrm{C}_{6} \mathrm{H}_{3} \mathrm{~S}\right)_{2}$ & $0 \%$ & $5 \%$ & $18 \%$ & $2 \%$ \\
9 & $\left(4-\mathrm{CF}_{3} \mathrm{C}_{6} \mathrm{H}_{4} \mathrm{~S}\right)_{2}$ & $0 \%$ & $4 \%$ & $68 \%$ & $4 \%$ \\
10 & $\left(3,5-\mathrm{dCF}_{3} \mathrm{C}_{6} \mathrm{H}_{3} \mathrm{~S}\right)_{2}$ & $0 \%$ & $3 \%$ & $\mathbf{5 4 \%}$ & $5 \%$
\end{tabular}

If necessary, disulfides were prepared from the corresponding thiols by perborate oxidation. ${ }^{21}$ 


\section{Supplementary Table S6: Evaluation of solvents and cosolvents for the epimerization}<smiles>O[C@H]1CCCC[C@H]1O</smiles>

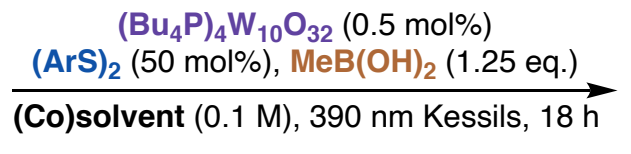<smiles>CB1OC2CCCCC2O1</smiles><smiles>O=C1CCCCC1O</smiles>

$0.1 \mathrm{mmol}$

\begin{tabular}{|c|c|c|c|c|c|}
\hline Entry & (Co)solvent & cis diol & trans diol/esters & cis ester & hydroxyketone \\
\hline 1 & $\mathrm{MeCN}$ & $0 \%$ & $4 \%$ & $70 \%$ & $4 \%$ \\
\hline 2 & tBuCN & $0 \%$ & $45 \%$ & $40 \%$ & $7 \%$ \\
\hline 3 & $\mathrm{PhCN}$ & $0 \%$ & $3 \%$ & $40 \%$ & $3 \%$ \\
\hline 4 & acetone & $0 \%$ & $21 \%$ & $62 \%$ & $0 \%$ \\
\hline 5 & tBuOAc & $0 \%$ & $98 \%$ & $2 \%$ & $0 \%$ \\
\hline 6 & $\mathrm{MeCN} / \mathrm{BuOH}(9: 1)$ & $0 \%$ & $93 \%$ & $5 \%$ & $3 \%$ \\
\hline 7 & $\mathrm{MeCN} / \mathrm{tBuOH}(1: 1)$ & $0 \%$ & $18 \%$ & $57 \%$ & $5 \%$ \\
\hline 8 & MeCN/acetone $(1: 1)$ & $0 \%$ & $8 \%$ & $64 \%$ & $0 \%$ \\
\hline 9 & MeCN/tBuOAc (1:1) & $0 \%$ & $8 \%$ & $61 \%$ & $7 \%$ \\
\hline 10 & MeCN/DCM (1:1) & $0 \%$ & $33 \%$ & $44 \%$ & $19 \%$ \\
\hline 11 & $\mathrm{MeCN} / \mathrm{CHCl}_{3}(1: 1)$ & $0 \%$ & $78 \%$ & $14 \%$ & $7 \%$ \\
\hline 12 & 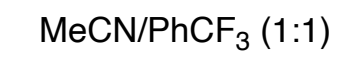 & $0 \%$ & $38 \%$ & $39 \%$ & $11 \%$ \\
\hline 13 & $\mathrm{MeCN} / \mathrm{o}-\mathrm{C}_{6} \mathrm{H}_{4} \mathrm{~F}_{2}(1: 1)$ & $0 \%$ & $31 \%$ & $51 \%$ & $11 \%$ \\
\hline 14 & $\mathrm{MeCN} / p-\mathrm{C}_{6} \mathrm{H}_{4} \mathrm{~F}_{2}(1: 1)$ & $0 \%$ & $89 \%$ & $10 \%$ & $4 \%$ \\
\hline 15 & MeCN/HFIP (1:1) & $0 \%$ & $55 \%$ & $15 \%$ & $15 \%$ \\
\hline 16 & $\mathrm{MeCN} / \mathrm{MeNO}_{2}(1: 1)$ & $0 \%$ & $12 \%$ & $20 \%$ & $7 \%$ \\
\hline
\end{tabular}




\section{6) Proposed reaction mechanism and mechanistic experiments}

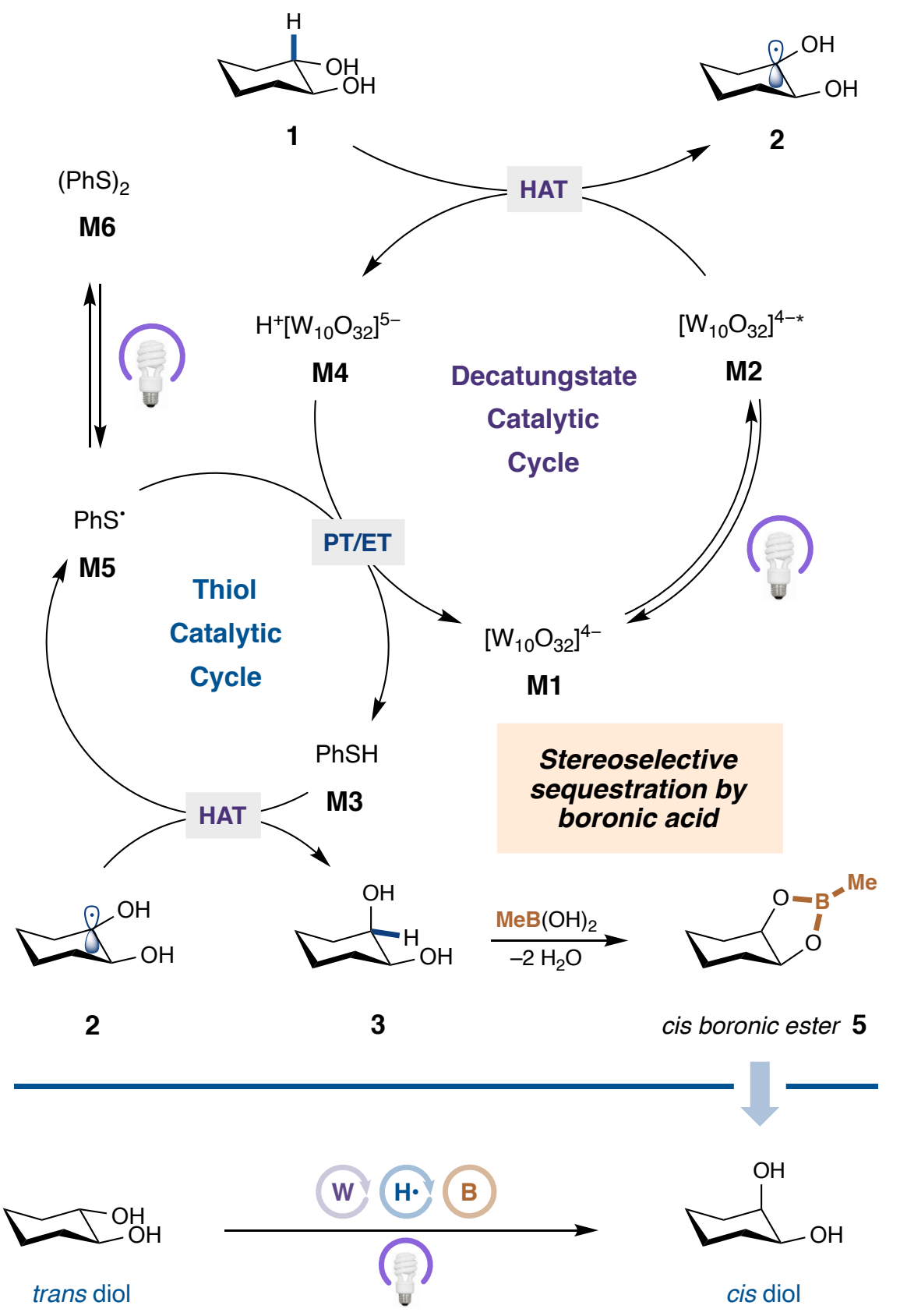

Supplementary Figure S6. Proposed reaction mechanism

Ground-state decatungstate (M1) absorbs a near-UV photon, with subsequent intersystem crossing producing the triplet excited state (M2) (lifetime $\tau=55 \mathrm{~ns}$ ). ${ }^{22}$ The resulting highlyreactive excited state then abstracts a hydrogen atom from the hydridic $\alpha$-oxy $\mathrm{C}-\mathrm{H}$ bond of trans diol 1, resulting in prochiral radical intermediate 2 . Thiophenol (M3) then unselectively quenches 
2, yielding either the original trans diol (1) or the cis isomer (3). Rapid trapping of 7 by methylboronic acid sequesters the less stable isomer as boronic ester $\mathbf{5}$, while any trans diol simply reenters the cycle to be epimerized again. Both catalytic cycles are simultaneously closed by favorable electron and proton transfer between reduced decatungstate M4 and thiyl radical M5, producing thiophenol (M3) and regenerating ground-state decatungstate. ${ }^{23}$ Thiyl radicals enter the catalytic cycle by light-driven homolysis of the S-S bond in diphenyl disulfide M6 under nearUV irradiation. After reaction completion, a transesterification workup reveals the cis diol product. 


\section{Supplementary Table S7: Epimerization with a quinuclidine/adamantanethiol system}<smiles>OC1CCCCC1O</smiles>

4-CzIPN (2 mol\%), quinuclidine (10 mol\%) $\underset{\mathrm{MeCN} / \mathrm{DMSO}(10: 1,0.2 \mathrm{M}), 420 \mathrm{~nm} \text { Kessils, } 3 \mathrm{~h}}{\stackrel{\mathrm{AdSH}}{\mathrm{MeB}(\mathrm{OH})_{2}(0 \text { or } 1.25 \text { equiv. })}}$<smiles>C[N+]1BOC2CCCCC2O1</smiles>

$0.1 \mathrm{mmol}$

\begin{tabular}{ccccccc} 
Entry & diol & $\mathrm{MeB}(\mathrm{OH})_{2}$ equiv. & trans diol & cis ester & cis diol & cis/trans ratio \\
\hline 1 & 0 & $30 \%$ & $0 \%$ & $65 \%$ & $2.2: 1$
\end{tabular}

2<smiles>OC1CCCCC1O</smiles>

3<smiles>OC1Cc2ccccc2CC1O</smiles>

4<smiles>CC(C)(C)OC(=O)N1C[C@@H](O)[C@H](O)C1</smiles>

1.25

1.25

1.25
$12 \%$

$55 \%$

$48 \%$
$77 \%$

$6 \%$

$0 \%$

0.3:1

The epimerization reactions were conducted according to the procedure of Wang et al. ${ }^{24}$ on 0.1 mmol scale, with the addition of 1.25 equiv. $\mathrm{MeB}(\mathrm{OH})_{2}$ when specified in the table. Yields determined by ${ }^{1} \mathrm{H}$ NMR vs. mesitylene, as an average of 2 runs. 


\section{7) Computational investigation of relative stabilities}

All of the quantum chemical calculations were performed using Gaussian $16 . .^{25}$ Geometry optimizations and frequency calculations were performed using the $\mathrm{B}^{2} \mathrm{LYP}^{26}$ functional with Grimme's D3 dispersion correction ${ }^{27}$ and $\mathrm{SMD}^{28}$ implicit acetonitrile solvation, and the $6-31+\mathrm{G}$ basis set on all elements.

Geometry optimization and frequency calculations were performed for cis- and trans-1,2cyclohexanediol, as well as the methylboronic esters and anionic methylboronates of both diols. The calculated energies of these species are summarized in Supplementary Table S8 below, and calculated differences between energies of epimers are included in Supplementary Table S9.

\section{Supplementary Table S8. Calculated energies of cis and trans diols and boronic esters.*}

\begin{tabular}{|c|c|c|c|c|}
\hline Species & $\begin{array}{c}\text { Sum of electronic } \\
\text { and zero-point } \\
\text { energies }\end{array}$ & $\begin{array}{c}\text { Sum of electronic } \\
\text { and thermal } \\
\text { energies }\end{array}$ & $\begin{array}{c}\text { Sum of electronic } \\
\text { and thermal } \\
\text { enthalpies }\end{array}$ & $\begin{array}{c}\text { Sum of electronic } \\
\text { and thermal free } \\
\text { energies }\end{array}$ \\
\hline $\begin{array}{c}\text { cis-1,2- } \\
\text { cyclohexanediol }\end{array}$ & -386.200486 & -386.192540 & -386.191596 & -386.232146 \\
\hline $\begin{array}{c}\text { trans-1,2- } \\
\text { cyclohexanediol }\end{array}$ & -386.202115 & -386.194115 & -386.193171 & -386.233899 \\
\hline $\begin{array}{c}\text { cis-1,2- } \\
\text { cyclohexanediol } \\
\text { methylboronic } \\
\text { ester }\end{array}$ & -449.853916 & -449.845434 & -449.844490 & -449.887118 \\
\hline $\begin{array}{c}\text { trans-1,2- } \\
\text { cyclohexanediol } \\
\text { methylboronic } \\
\text { ester }\end{array}$ & -449.848692 & -449.839367 & -449.838423 & -449.883934 \\
\hline $\begin{array}{c}\text { cis-1,2- } \\
\text { cyclohexanediol } \\
\text { cis- }\end{array}$ & -525.807849 & -525.797096 & -525.796152 & -525.843337 \\
\hline $\begin{array}{c}\text { methylboronate } \\
\text { cis-1,2- } \\
\text { cyclohexanediol } \\
\text { trans- } \\
\text { methylboronate }\end{array}$ & -525.807717 & -525.796894 & -525.795950 & -525.843357 \\
\hline $\begin{array}{c}\text { trans-1,2- } \\
\text { cyclohexanediol } \\
\text { methylboronate }\end{array}$ & -525.804321 & -525.793550 & -525.792606 & -525.839919 \\
\hline
\end{tabular}

*Energies reported in Hartrees 
Supplementary Table S9. Calculated difference between energies of epimers*

\begin{tabular}{|c|c|c|}
\hline Species & Enthalpy difference & Free energy difference \\
\hline cis diol - trans diol & 0.99 & 1.10 \\
\hline cis ester - trans ester & -3.22 & -2.00 \\
\hline cis, cis boronate - trans boronate & -2.23 & -2.14 \\
\hline
\end{tabular}

*Energies reported in $\mathrm{kcal} / \mathrm{mol}$

While we have proposed that selectivity in this reaction is derived from the difference in stability between the cis and trans boronic esters, tetracoordinated boronates could also be relevant intermediates in determining selectivity. Both boronic esters and anionic boronates demonstrate a clear thermodynamic preference for the cis ring fusion, consistent with trends in ring strain of 5/6 fused systems.

\section{Calculated geometries for diols, esters, and anionic boronates}

\section{cis-1,2-cyclohexanediol}

B3LYP $/ 6-31+\mathrm{G}(\mathrm{d}, \mathrm{p}) \mathrm{scrf}=(\mathrm{smd}$, solvent $=$ acetonitrile $)$ empiricaldispersion $=\mathrm{gd} 3$

$\begin{array}{lrrr}\mathrm{C} & 0.8553340 & 0.4798650 & -0.5158060 \\ \mathrm{C} & 0.0352680 & 1.4142460 & 0.3761910 \\ \mathrm{C} & -1.4666310 & 1.2725110 & 0.0771680 \\ \mathrm{C} & -1.9237760 & -0.1856340 & 0.2365620 \\ \mathrm{C} & -1.0844750 & -1.1291560 & -0.6395950 \\ \mathrm{C} & 0.4154380 & -0.9832970 & -0.3791680 \\ \mathrm{H} & -2.0413450 & 1.9299260 & 0.7401590 \\ \mathrm{H} & 0.2325560 & 1.1603680 & 1.4250950 \\ \mathrm{H} & 0.3662480 & 2.4490770 & 0.2189860 \\ \mathrm{H} & 0.7210370 & 0.7701650 & -1.5689450 \\ \mathrm{H} & -1.8254490 & -0.4835540 & 1.2879840 \\ \mathrm{H} & -2.9837030 & -0.2829770 & -0.0274950 \\ \mathrm{H} & -1.3697840 & -2.1748030 & -0.4754350 \\ \mathrm{H} & -1.2663900 & -0.9073650 & -1.6995700 \\ \mathrm{H} & 0.9798550 & -1.5816830 & -1.1105380 \\ \mathrm{H} & -1.6645190 & 1.6053400 & -0.9519690 \\ \mathrm{O} & 0.6929880 & -1.4766410 & 0.9423140 \\ \mathrm{H} & 1.5936400 & -1.1928340 & 1.1653800 \\ \mathrm{O} & 2.2582820 & 0.5065900 & -0.1867120 \\ \mathrm{H} & 2.5376920 & 1.4298000 & -0.0904050\end{array}$




\section{trans-1,2-cyclohexanediol}

B3LYP $/ 6-31+\mathrm{G}(\mathrm{d}, \mathrm{p}) \mathrm{scrf}=(\mathrm{smd}, \mathrm{solvent}=$ acetonitrile $)$ empiricaldispersion $=\mathrm{gd} 3$

$\begin{array}{lrrr}\mathrm{C} & -1.8852450 & 0.7544060 & -0.2807880 \\ \mathrm{C} & -1.9171670 & -0.6780090 & 0.2756530 \\ \mathrm{C} & -0.6611120 & -1.4616530 & -0.1365010 \\ \mathrm{C} & 0.6114430 & -0.7308440 & 0.2854660 \\ \mathrm{C} & 0.6422730 & 0.6875390 & -0.2810520 \\ \mathrm{C} & -0.5974560 & 1.4796450 & 0.1422800 \\ \mathrm{H} & -0.6606990 & -2.4638610 & 0.3072860 \\ \mathrm{H} & -1.9779200 & -0.6384240 & 1.3723630 \\ \mathrm{H} & -2.8132210 & -1.2040370 & -0.0739400 \\ \mathrm{H} & -1.9383980 & 0.7179790 & -1.3781080 \\ \mathrm{H} & -2.7608450 & 1.3182050 & 0.0618190 \\ \mathrm{H} & 0.6416640 & -0.6532920 & 1.3849110 \\ \mathrm{H} & 0.6812210 & 0.6141480 & -1.3787010 \\ \mathrm{H} & -0.5760940 & 1.5988260 & 1.2340640 \\ \mathrm{H} & -0.5515780 & 2.4842760 & -0.2963830 \\ \mathrm{H} & -0.6419420 & -1.5880380 & -1.2276320 \\ \mathrm{O} & 1.8618000 & 1.2882960 & 0.1986600 \\ \mathrm{H} & 2.0126890 & 2.1132210 & -0.2868910 \\ \mathrm{O} & 1.7408630 & -1.4917450 & -0.1675320 \\ \mathrm{H} & 2.5299030 & -0.9490010 & -0.0125250\end{array}$

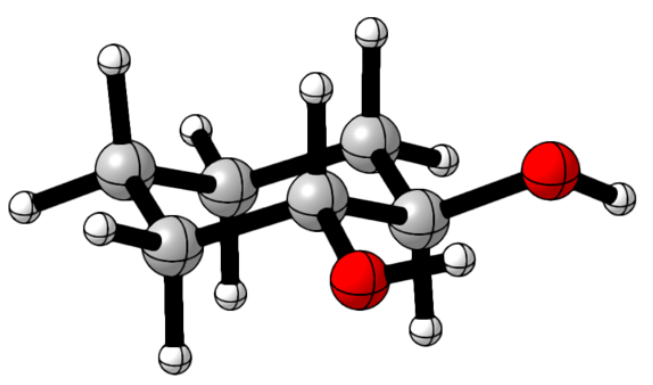

cis-1,2-cyclohexanediol methylboronic ester

B3LYP/6-31+G(d,p) scrf $=($ smd,solvent $=$ acetonitrile $)$ empiricaldispersion $=\mathrm{gd} 3$

$\begin{array}{lrrr}\mathrm{C} & -2.3076290 & 0.8461190 & -0.4296930 \\ \mathrm{C} & -0.9061760 & 1.4514950 & -0.2707830 \\ \mathrm{C} & -0.0931070 & 0.7583580 & 0.8311660 \\ \mathrm{C} & -0.1602690 & -0.7808330 & 0.8029500 \\ \mathrm{C} & -1.4960390 & -1.3912480 & 0.3951060 \\ \mathrm{C} & -2.1967930 & -0.6506590 & -0.7507830 \\ \mathrm{H} & -0.3662980 & 1.3334350 & -1.2193490 \\ \mathrm{H} & -0.9517920 & 2.5255880 & -0.0590210 \\ \mathrm{H} & -2.8865510 & 0.9819710 & 0.4952590 \\ \mathrm{H} & -2.8466530 & 1.3747370 & -1.2244180 \\ \mathrm{H} & 0.1305650 & -1.1753130 & 1.7853130 \\ \mathrm{H} & -1.3349500 & -2.4486790 & 0.1548480 \\ \mathrm{H} & -2.1439040 & -1.3635000 & 1.2816360 \\ \mathrm{H} & -1.6329180 & -0.7799110 & -1.6845640 \\ \mathrm{H} & -3.1891490 & -1.0876880 & -0.9126990 \\ \mathrm{H} & -0.3631990 & 1.1444840 & 1.8178960 \\ \mathrm{O} & 1.3248890 & 1.0158680 & 0.6043870 \\ \mathrm{O} & 0.9207210 & -1.1282900 & -0.1164420 \\ \mathrm{~B} & 1.8189780 & -0.0807050 & -0.0774180 \\ \mathrm{C} & 3.2302870 & -0.1214770 & -0.7560670 \\ \mathrm{H} & 3.8735540 & 0.6986950 & -0.4199940\end{array}$

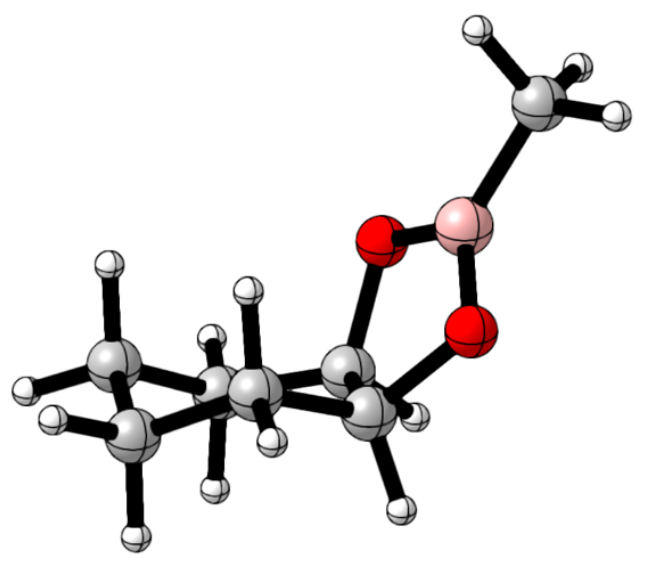




$\begin{array}{llll}\mathrm{H} & 3.7440070 & -1.0716260 & -0.5676680 \\ \mathrm{H} & 3.1198880 & -0.0302080 & -1.8458550\end{array}$

trans-1,2-cyclohexanediol methylboronic ester

B3LYP $/ 6-31+\mathrm{G}(\mathrm{d}, \mathrm{p}) \mathrm{scrf}=(\mathrm{smd}, \mathrm{solvent}=$ acetonitrile $)$ empiricaldispersion $=\mathrm{gd} 3$

$\begin{array}{lrrr}\mathrm{C} & -2.5371940 & -0.7468000 & -0.1878640 \\ \mathrm{C} & -1.2559180 & -1.5066090 & 0.2439790 \\ \mathrm{C} & -0.0920730 & -0.7014030 & -0.2969120 \\ \mathrm{C} & -0.0873640 & 0.6999730 & 0.2840560 \\ \mathrm{C} & -1.2566470 & 1.5071460 & -0.2420140 \\ \mathrm{C} & -2.5336930 & 0.7492640 & 0.2054050 \\ \mathrm{H} & -1.1938630 & -1.5735040 & 1.3376000 \\ \mathrm{H} & -1.2607880 & -2.5251660 & -0.1595930 \\ \mathrm{H} & -2.6366790 & -0.8284990 & -1.2787960 \\ \mathrm{H} & -3.4172020 & -1.2344860 & 0.2460640 \\ \mathrm{H} & -1.2548340 & 2.5255950 & 0.1618470 \\ \mathrm{H} & -1.2080050 & 1.5742210 & -1.3363050 \\ \mathrm{H} & -2.6197880 & 0.8310930 & 1.2974730 \\ \mathrm{H} & -3.4181860 & 1.2382700 & -0.2177710 \\ \mathrm{H} & -0.1862170 & -0.6398690 & -1.3918440 \\ \mathrm{O} & 1.2625750 & -1.1588150 & -0.0254970 \\ \mathrm{O} & 1.2641530 & 1.1549880 & -0.0050950 \\ \mathrm{~B} & 2.0313630 & -0.0026730 & -0.0138430 \\ \mathrm{C} & 3.5965620 & 0.0006970 & 0.0155080 \\ \mathrm{H} & 4.0223110 & -0.8865110 & -0.4658310 \\ \mathrm{H} & 4.0083610 & 0.8958590 & -0.4643310 \\ \mathrm{H} & 3.9463900 & 0.0060720 & 1.0577440 \\ \mathrm{H} & -0.1677740 & 0.6382130 & 1.3801660\end{array}$

cis-1,2-cyclohexanediol cis-methylboronate

B3LYP/6-31 $\mathrm{G}(\mathrm{d}, \mathrm{p}) \mathrm{scrf}=(\mathrm{smd}, \mathrm{solvent}=$ acetonitrile $)$ empiricaldispersion $=\mathrm{gd} 3$

$\begin{array}{lrrr}\mathrm{C} & -2.1634690 & 0.8552440 & -0.6774730 \\ \mathrm{C} & -0.7377590 & 1.3611580 & -0.4159700 \\ \mathrm{C} & -0.1097170 & 0.7379260 & 0.8466280 \\ \mathrm{C} & -0.2577290 & -0.7975460 & 0.8905050 \\ \mathrm{C} & -1.6199940 & -1.3374600 & 0.4468790 \\ \mathrm{C} & -2.1598420 & -0.6733510 & -0.8274180 \\ \mathrm{H} & -0.1073410 & 1.0956720 & -1.2739410 \\ \mathrm{H} & -0.7114040 & 2.4551860 & -0.3276040 \\ \mathrm{H} & -2.8207390 & 1.1367910 & 0.1595460 \\ \mathrm{H} & -2.5760690 & 1.3309500 & -1.5764520 \\ \mathrm{H} & -0.0867600 & -1.1226810 & 1.9362520 \\ \mathrm{H} & -1.5459120 & -2.4259270 & 0.3238540 \\ \mathrm{H} & -2.3340130 & -1.1589790 & 1.2643680\end{array}$

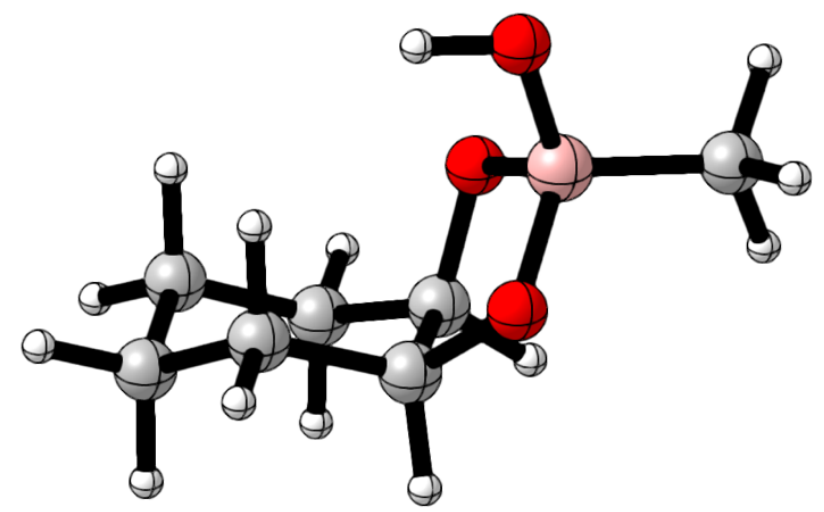




$\begin{array}{lrrr}\mathrm{H} & -1.5311730 & -0.9483490 & -1.6851670 \\ \mathrm{H} & -3.1707970 & -1.0442770 & -1.0400920 \\ \mathrm{H} & -0.5728670 & 1.1961470 & 1.7359480 \\ \mathrm{O} & 1.2952820 & 0.9295750 & 0.8783680 \\ \mathrm{O} & 0.8095730 & -1.2443230 & 0.0747330 \\ \mathrm{~B} & 1.9711760 & -0.3105220 & 0.3122800 \\ \mathrm{C} & 3.0579040 & -0.9040540 & 1.3785840 \\ \mathrm{H} & 3.5805540 & -1.7903140 & 0.9857990 \\ \mathrm{H} & 3.8306320 & -0.1624320 & 1.6362190 \\ \mathrm{H} & 2.5741060 & -1.2020320 & 2.3212760 \\ \mathrm{O} & 2.6701900 & -0.0416420 & -0.9602750 \\ \mathrm{H} & 2.0199650 & 0.2866670 & -1.5949110\end{array}$

cis-1,2-cyclohexanediol trans-methylboronate

B3LYP/6-31+G(d,p) scrf $=($ smd,solvent $=$ acetonitrile $)$ empiricaldispersion $=\mathrm{gd} 3$

$\begin{array}{lrrr}\mathrm{C} & -2.0697620 & 0.8173010 & -0.6622870 \\ \mathrm{C} & -0.6599500 & 1.3686150 & -0.4073130 \\ \mathrm{C} & -0.0172990 & 0.7868160 & 0.8660900 \\ \mathrm{C} & -0.1226720 & -0.7505120 & 0.9404760 \\ \mathrm{C} & -1.4670990 & -1.3381810 & 0.5025670 \\ \mathrm{C} & -2.0212790 & -0.7127500 & -0.7851860 \\ \mathrm{H} & -0.0173870 & 1.1061960 & -1.2562070 \\ \mathrm{H} & -0.6670230 & 2.4642500 & -0.3364320 \\ \mathrm{H} & -2.7375310 & 1.0943700 & 0.1679480 \\ \mathrm{H} & -2.4932310 & 1.2650030 & -1.5705470 \\ \mathrm{H} & 0.0517790 & -1.0515080 & 1.9936520 \\ \mathrm{H} & -1.3592320 & -2.4257570 & 0.3981660 \\ \mathrm{H} & -2.1899500 & -1.1676880 & 1.3140450 \\ \mathrm{H} & -1.3816050 & -0.9841390 & -1.6358140 \\ \mathrm{H} & -3.0202060 & -1.1167940 & -0.9944390 \\ \mathrm{H} & -0.4878490 & 1.2495610 & 1.7488260 \\ \mathrm{O} & 1.3827310 & 1.0185830 & 0.8898010 \\ \mathrm{O} & 0.9586820 & -1.1822960 & 0.1330930 \\ \mathrm{~B} & 2.0890320 & -0.2052120 & 0.3385300 \\ \mathrm{C} & 2.8818360 & 0.0581000 & -1.0612070 \\ \mathrm{H} & 3.6691570 & 0.8191870 & -0.9474020 \\ \mathrm{H} & 3.3740220 & -0.8567850 & -1.4276390 \\ \mathrm{H} & 2.2068820 & 0.4031280 & -1.8576390 \\ \mathrm{O} & 3.0810300 & -0.6782890 & 1.3399320 \\ \mathrm{H} & 2.6546330 & -0.6789870 & 2.2068380\end{array}$

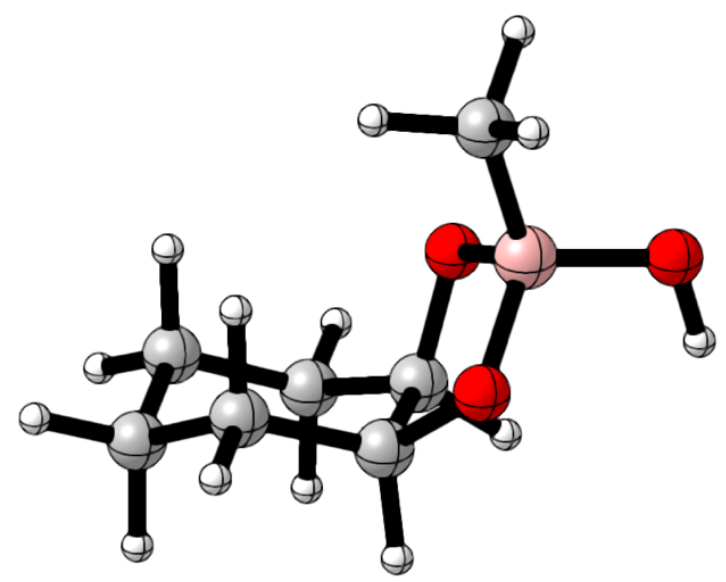


trans-1,2-cyclohexanediol methylboronate

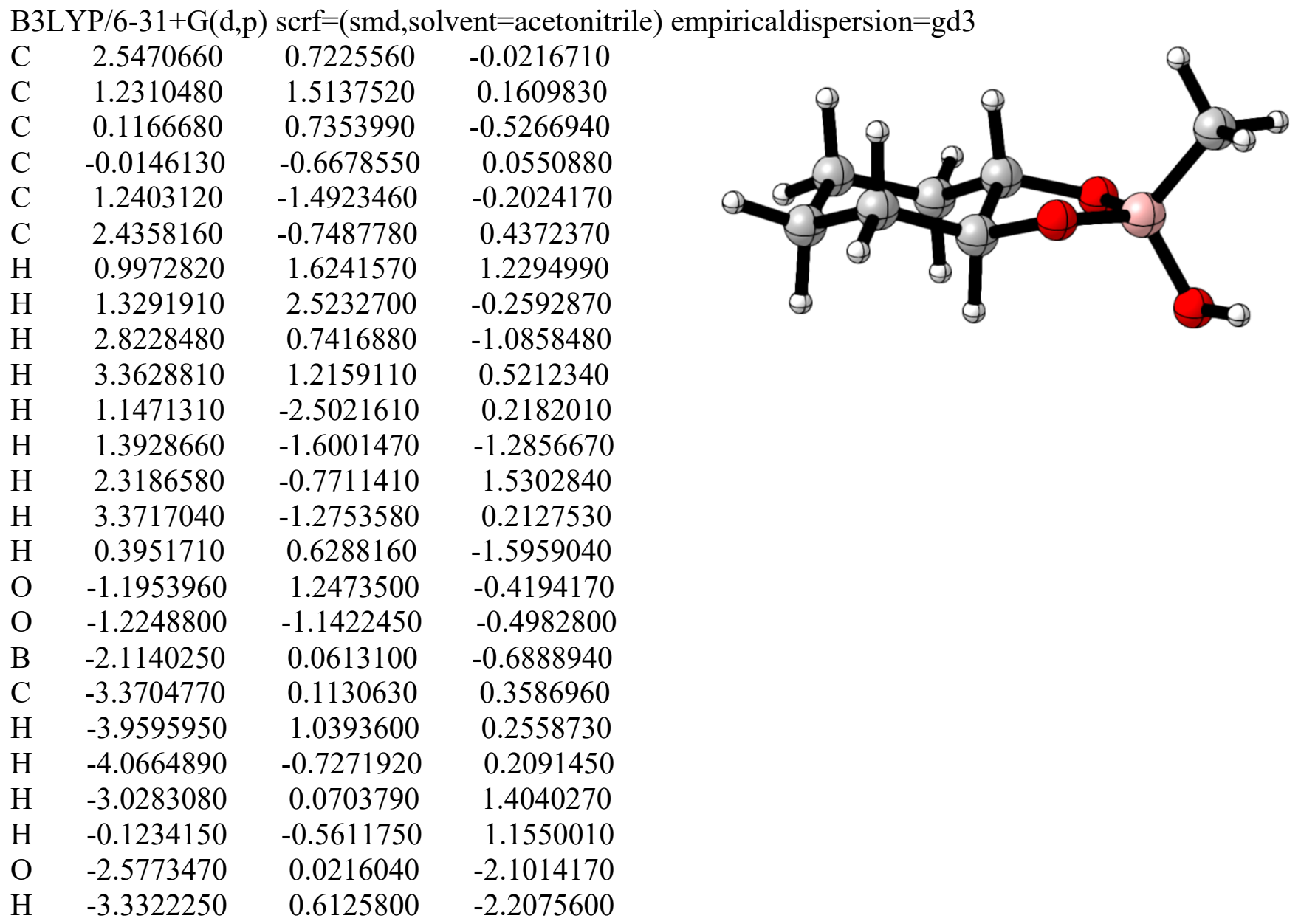




\section{8) General procedure for diastereoselective epimerization}

To an $8 \mathrm{~mL}$ screw-cap vial equipped with a septum and stir bar was added substrate $(0.5$ mmol, 1 equiv.), methylboronic acid (37.4 mg, $0.625 \mathrm{mmol}, 1.25$ equiv.), diphenyl disulfide (54.5 $\mathrm{mg}, 0.25 \mathrm{mmol}, 50 \mathrm{~mol} \%$ ), and tetrabutylphosphonium decatungstate $(8.5 \mathrm{mg}, 2.5 \mu \mathrm{mol}, 0.5 \mathrm{~mol}$ $\%$ ), followed by dry acetonitrile $(5.0 \mathrm{~mL})$ for a reaction concentration of $0.1 \mathrm{M}$ relative to substrate. The resulting mixture was stirred or sonicated briefly to homogeneity, then sparged for 15 minutes with nitrogen with vials placed in an ice bath to prevent solvent evaporation. After sparging, vials were sealed using a hot glue gun and electrical tape (see Supplementary Figure S1 above), then irradiated for 12-36 hours in a PennOC Integrated Photoreactor using a 365nm LED module, with $100 \%$ light intensity, $400 \mathrm{rpm}$ stir rate, and maximum fan speed. After reaction completion, vials were removed from the Integrated Photoreactor, opened to air, mesitylene $(12.0 \mathrm{mg}, 14 \mu \mathrm{L}, 0.2$ equiv.) was added via microsyringe and an aliquot was removed and analyzed by ${ }^{1} \mathrm{H}$ NMR.

\section{General workup and purification procedure:}

After an aliquot was taken for ${ }^{1} \mathrm{H}$ NMR analysis, (1S,2S,3R,5S)-(+)-pinanediol (128 mg, 0.75 mmol, 1.5 equiv.) and anhydrous $\mathrm{K}_{2} \mathrm{CO}_{3}(345 \mathrm{mg}, 2.5 \mathrm{mmol}, 5$ equiv.) were added. The resulting mixture was stirred rapidly for at least 4 hours, then filtered through a disposable frit and concentrated to remove a majority of the solvent. The residue was directly loaded onto a preequilibrated silica gel column and purified by automated flash chromatography (see below for specific column conditions). Product-containing fractions were identified by ELS detector trace and visualized on thin-layer chromatography using $5 \%$ or $10 \%$ methanol/dichloromethane as solvent and potassium permanganate stain or fluorescence quenching. Product-containing fractions were then concentrated in vacuo to afford the desired product. 


\section{9) Experimental data for epimerized products}

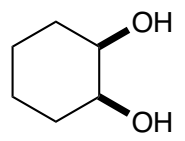

\section{cis-1-2-cyclohexanediol (3)}

Prepared following the general procedure using trans-1,2-cyclohexanediol $(58.1 \mathrm{mg}, 0.5$ mmol, 1.0 equiv.), methylboronic acid (37.4 mg, $0.625 \mathrm{mmol}, 1.25$ equiv.), diphenyl disulfide (54.5 mg, $0.25 \mathrm{mmol}, 50 \mathrm{~mol} \%$ ), tetrabutylphosphonium decatungstate $(8.5 \mathrm{mg}, 2.5 \mu \mathrm{mol}, 0.5$ $\mathrm{mol} \%$ ) and acetonitrile $(5 \mathrm{~mL})$. After 12 hours of irradiation, the vial was removed, opened to air, and (1S,2S,3R,5S)-(+)-pinanediol (128 mg, $0.75 \mathrm{mmol}, 1.5$ equiv.) and anhydrous $\mathrm{K}_{2} \mathrm{CO}_{3}(345$ mg, 2.5 mmol, 5 equiv.) were added. The resulting suspension was rapidly stirred for 6 hours, filtered through a disposable frit and concentrated to remove a majority of the solvent. The residue was purified by flash column chromatography (silica, $0-10 \% \mathrm{MeOH} / \mathrm{DCM}$ ) to provide the title compound as an off-white solid (40.6 mg, $0.35 \mathrm{mmol}, 18.9: 1$ cis/trans ratio by ${ }^{1} \mathrm{H} \mathrm{NMR,} \mathrm{70 \%}$ combined yield, $66 \%$ yield title compound). ${ }^{1} \mathrm{H}$ NMR shifts were consistent with those reported in the literature. ${ }^{29}$

${ }^{1}$ H NMR: $\delta 3.93-3.58(\mathrm{~m}, 2 \mathrm{H}), 1.93$ (br s, 2H), $1.82-1.73(\mathrm{~m}, 2 \mathrm{H}), 1.67-1.51$ (m, 4H), $1.38-$ $1.24(\mathrm{~m}, 2 \mathrm{H})$.<smiles>OC1CCOCC1O</smiles>

\section{( \pm -cis-3,4-tetrahydropyrandiol (6)}

Prepared following the general procedure using trans-tetrahydropyran-3,4-diol $(59.1 \mathrm{mg}$, $0.5 \mathrm{mmol}, 1.0$ equiv.), methylboronic acid (37.4 $\mathrm{mg}, 0.625 \mathrm{mmol}, 1.25$ equiv.), diphenyl disulfide (54.5 mg, $0.25 \mathrm{mmol}, 50 \mathrm{~mol} \%$ ), tetrabutylphosphonium decatungstate $(8.5 \mathrm{mg}, 2.5 \mu \mathrm{mol}, 0.5$ mol\%) and acetonitrile ( $5 \mathrm{~mL})$. After 12 hours of irradiation, the vial was removed, opened to air, and (1S,2S,3R,5S)-(+)-pinanediol (128 mg, 0.75 mmol, 1.5 equiv.) and anhydrous $\mathrm{K}_{2} \mathrm{CO}_{3}(345$ mg, 2.5 mmol, 5 equiv.) were added. The resulting suspension was rapidly stirred for 4 hours, 
filtered through a disposable frit and concentrated to remove a majority of the solvent. The residue was purified by flash column chromatography (silica, $0-10 \% \mathrm{MeOH} / \mathrm{DCM}$ ) to provide the title compound as a light yellow oil (44.2 mg, $0.37 \mathrm{mmol}, 74 \%$ yield title compound, $>95 \%$ pure with trace inseparable cis isomer).

${ }^{1}$ H NMR (500 MHz, $\left.\mathbf{C D C l}_{3}\right) \delta 3.91-3.81(\mathrm{~m}, 2 \mathrm{H}), 3.79-3.73(\mathrm{~m}, 1 \mathrm{H}), 3.54(\mathrm{dd}, J=12.0,2.4$ Hz, 1H), 3.44 (ddd, $J=12.0,8.8,3.7 \mathrm{~Hz}, 1 \mathrm{H}), 2.28$ (br s, 2H), $1.91-1.74$ (m, 2H).

${ }^{13}$ C NMR (126 MHz, CDCl $)$ ) $\delta$ 69.58, 68.39, 68.04, 65.04, 30.70.

IR (film) $v_{\max } 3361,2864,1653,1232,1153,1081,1029,1004,857,808$

HRMS (EI-TOF) $m / z$ calcd. for $\mathrm{C}_{5} \mathrm{H}_{10} \mathrm{O}_{3}{ }^{+}\left([\mathrm{M}]^{+}\right) 118.06299$, found 118.06325

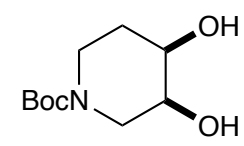

\section{( \pm )-N-Boc-cis-3,4-piperidinediol (7)}

Prepared following the general procedure using $N$-Boc-trans-3,4-piperidinediol (108.6 mg, $0.5 \mathrm{mmol}, 1.0$ equiv.), methylboronic acid (37.4 $\mathrm{mg}, 0.625 \mathrm{mmol}, 1.25$ equiv.), diphenyl disulfide (54.5 mg, $0.25 \mathrm{mmol}, 50 \mathrm{~mol} \%$ ), tetrabutylphosphonium decatungstate $(8.5 \mathrm{mg}, 2.5 \mu \mathrm{mol}, 0.5$ $\mathrm{mol} \%$ ) and acetonitrile $(5 \mathrm{~mL})$. After 12 hours of irradiation, the vial was removed, opened to air, and (1S,2S,3R,5S)-(+)-pinanediol (128 mg, $0.75 \mathrm{mmol}, 1.5$ equiv.) and anhydrous $\mathrm{K}_{2} \mathrm{CO}_{3}(345$ $\mathrm{mg}, 2.5 \mathrm{mmol}, 5$ equiv.) were added. The resulting suspension was rapidly stirred for 4 hours, filtered through a disposable frit and concentrated to remove a majority of the solvent. The residue was purified by flash column chromatography (silica, 0-10\% $\mathrm{MeOH} / \mathrm{DCM}$ ) to provide the title compound as a light yellow oil (72.8 mg, $0.34 \mathrm{mmol}, 67 \%$ yield title compound). ${ }^{1} \mathrm{H}$ NMR shifts were consistent with those reported in the literature. ${ }^{3}$

${ }^{1}$ H NMR (500 MHz, CDCl $)$ ) 3.92 - 3.84 (m, 1H), 3.78 (br s, 1H), 3.65 - 3.52 (m, 2H), 3.41 (dd, $J=13.4,3.4 \mathrm{~Hz}, 1 \mathrm{H}), 3.25(\mathrm{ddd}, J=13.5,7.5,4.0 \mathrm{~Hz}, 1 \mathrm{H}), 1.87-1.76(\mathrm{~m}, 1 \mathrm{H}), 1.77-1.65(\mathrm{~m}$, $1 \mathrm{H}), 1.46(\mathrm{~s}, 9 \mathrm{H})$. 


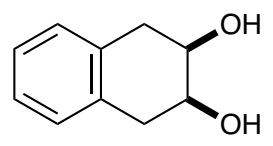

\section{cis-1,2,3,4-tetrahydronaphthalene-2,3-diol (8)}

Prepared using a modification of the general procedure using trans-1,2,3,4tetrahydronaphthalene-2,3-diol ( $82.1 \mathrm{mg}, 0.5 \mathrm{mmol}, 1.0$ equiv.), methylboronic acid (37.4 mg, $0.625 \mathrm{mmol}, 1.25$ equiv.), diphenyl disulfide (54.5 $\mathrm{mg}, 0.25 \mathrm{mmol}, 50 \mathrm{~mol} \%)$, tetrabutylphosphonium decatungstate $(8.5 \mathrm{mg}, 2.5 \mu \mathrm{mol}, 0.5 \mathrm{~mol} \%)$ and acetonitrile $(5 \mathrm{~mL})$. After 18 hours of irradiation, the vial was removed, opened to air, and (1S,2S,3R,5S)-(+)-pinanediol (128 mg, 0.75 mmol, 1.5 equiv.) and anhydrous $\mathrm{K}_{2} \mathrm{CO}_{3}$ (345 mg, $2.5 \mathrm{mmol}, 5$ equiv.) were added. The resulting suspension was rapidly stirred for 4 hours, filtered through a disposable frit and concentrated to remove a majority of the solvent. The residue was purified by flash column chromatography (silica, $0-3 \% \mathrm{MeOH} / \mathrm{DCM}$ ) to provide the title compound as a white solid (55.1 mg, $0.34 \mathrm{mmol}, 67 \%$ yield title compound). ${ }^{1} \mathrm{H}$ NMR shifts were consistent with those reported in the literature. ${ }^{29}$

${ }^{1}$ H NMR (500 MHz, CDCl $) \delta 7.16$ - 7.08 (m, 4H), 4.25 - 4.11 (m, 2H), 3.17 - 2.94 (m, 4H), $2.00(\mathrm{~s}, 2 \mathrm{H})$.

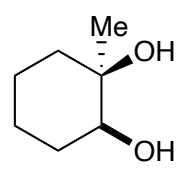

\section{( \pm )-cis-1-methylcyclohexane-1,2-diol (9)}

Prepared following the general procedure using $(1 R S, 2 R S)$-1-methylcyclohexane-1,2-diol (65.1 mg, $0.5 \mathrm{mmol}, 1.0$ equiv.), methylboronic acid (37.4 mg, $0.625 \mathrm{mmol}, 1.25$ equiv.), diphenyl disulfide (54.5 mg, $0.25 \mathrm{mmol}, 50 \mathrm{~mol} \%$ ), tetrabutylphosphonium decatungstate $(8.5 \mathrm{mg}, 2.5$ $\mu \mathrm{mol}, 0.5 \mathrm{~mol} \%$ ) and acetonitrile $(5 \mathrm{~mL})$. After 12 hours of irradiation, the vial was removed, opened to air, and (1S,2S,3R,5S)-(+)-pinanediol (128 mg, $0.75 \mathrm{mmol}, 1.5$ equiv.) and anhydrous $\mathrm{K}_{2} \mathrm{CO}_{3}$ (345 mg, $2.5 \mathrm{mmol}, 5$ equiv.) were added. The resulting suspension was rapidly stirred for 4 hours, filtered through a disposable frit and concentrated to remove a majority of the solvent. The residue was purified by flash column chromatography (silica, 0-5\% MeOH/DCM) to provide 
the title compound as a light yellow oil that solidified upon standing ( $44.9 \mathrm{mg}, 0.34 \mathrm{mmol}, 69 \%$ yield title compound). ${ }^{1} \mathrm{H}$ NMR shifts were consistent with those reported in the literature. ${ }^{5}$

${ }^{1}$ H NMR (500 MHz, CD 3 CN) $\delta 3.29-3.23(\mathrm{~m}, 1 \mathrm{H}), 2.67(\mathrm{~d}, J=5.5 \mathrm{~Hz}, 1 \mathrm{H}), 2.41(\mathrm{~s}, 1 \mathrm{H}), 1.70$ -1.55 (m, 3H), $1.55-1.43$ (m, 2H), $1.39-1.19$ (m, 3H), 1.13 (s, 3H).

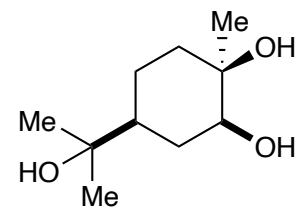

\section{$( \pm)-(1 R S, 2 R S, 4 R S)-$ menthanetriol (10)}

Prepared following a modification of the general procedure using $( \pm)-(1 \mathrm{RS}, 2 \mathrm{RS}, 4 \mathrm{SR})-$ menthanetriol (94.1 mg, $0.5 \mathrm{mmol}, 1.0$ equiv.), methylboronic acid (37.4 mg, $0.625 \mathrm{mmol}, 1.25$ equiv.), diphenyl disulfide ( $54.5 \mathrm{mg}, 0.25 \mathrm{mmol}, 50 \mathrm{~mol} \%$ ), tetrabutylphosphonium decatungstate ( $8.5 \mathrm{mg}, 2.5 \mu \mathrm{mol}, 0.5 \mathrm{~mol} \%$ ) and acetonitrile $(5 \mathrm{~mL})$. After 4 hours of irradiation, the vial was removed, opened to air, and mesitylene, (14.0 $\mu \mathrm{L}, 0.1 \mathrm{mmol}, 0.2$ equiv.), 1S,2S,3R,5S)-(+)pinanediol (128 mg, $1.5 \mathrm{mmol}, 1.5$ equiv.) and anhydrous $\mathrm{K}_{2} \mathrm{CO}_{3}(345 \mathrm{mg}, 2.5 \mathrm{mmol}, 5$ equiv.) were added. The resulting suspension was rapidly stirred for 4 hours and an aliquot was removed and analyzed by ${ }^{1} \mathrm{H}$ NMR $\left(\mathrm{CD}_{3} \mathrm{CN}\right)$ to determine an analytical yield (67\% analytical yield). The solution was then filtered through a disposable frit and concentrated to remove a majority of the solvent. The residue was purified by flash column chromatography (silica, 5-10\% $\mathrm{MeOH} / \mathrm{DCM}$ ) to provide the title compound as an off-white solid $(47.7 \mathrm{mg}, 0.25 \mathrm{mmol}, 51 \%$ yield title compound). ${ }^{13} \mathrm{C}$ NMR shifts (acetone- $\mathrm{d}_{6}$ ) were consistent with those reported in the literature for the $(1 S, 2 S, 4 S)$ isomer. $^{6}$

${ }^{1} \mathrm{H}$ NMR (400 MHz, CD $\mathbf{C D N}_{3}$ ) $\delta 3.24(\mathrm{ddd}, J=11.2,6.6,4.6 \mathrm{~Hz}, 1 \mathrm{H}), 2.63(\mathrm{~d}, J=6.6 \mathrm{~Hz}, 1 \mathrm{H})$, $2.30(\mathrm{~d}, J=0.9 \mathrm{~Hz}, 1 \mathrm{H}), 2.24(\mathrm{~s}, 1 \mathrm{H}), 1.75-1.66(\mathrm{~m}, 2 \mathrm{H}), 1.50-1.43(\mathrm{~m}, 1 \mathrm{H}), 1.34-1.20(\mathrm{~m}$, $4 \mathrm{H}), 1.14(\mathrm{~s}, 3 \mathrm{H}), 1.09(\mathrm{~s}, 6 \mathrm{H})$.

${ }^{13}$ C NMR (126 MHz, Acetone-d $)$ ) $\delta$ 75.91, 71.62, 70.82, 48.87, 38.41, 32.66, 27.72, 27.56, 27.36, 22.90 . 


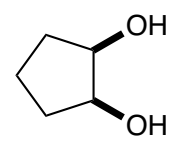

\section{cis-1,2-cyclopentanediol (11)}

Prepared following the general procedure using trans-1,2-cyelopentanediol $(51.1 \mathrm{mg}, 0.5$ mmol, 1.0 equiv.), methylboronic acid (37.4 mg, $0.625 \mathrm{mmol}, 1.25$ equiv.), diphenyl disulfide (54.5 mg, $0.25 \mathrm{mmol}, 50 \mathrm{~mol} \%$ ), tetrabutylphosphonium decatungstate $(8.5 \mathrm{mg}, 2.5 \mu \mathrm{mol}, 0.5$ $\mathrm{mol} \%$ ) and acetonitrile $(5 \mathrm{~mL})$. After 12 hours of irradiation, the vial was removed, opened to air, and (1S,2S,3R,5S)-(+)-pinanediol (128 mg, $0.75 \mathrm{mmol}, 1.5$ equiv.) and anhydrous $\mathrm{K}_{2} \mathrm{CO}_{3}(345$ mg, 2.5 mmol, 5 equiv.) were added. The resulting suspension was rapidly stirred for 6 hours, filtered through a disposable frit and concentrated to remove a majority of the solvent. The residue was purified by flash column chromatography (silica, 0-10\% $\mathrm{MeOH} / \mathrm{DCM}$ ) to provide the title compound as an off-white solid (30.9 mg, $0.30 \mathrm{mmol}, 61 \%$ yield title compound). ${ }^{1} \mathrm{H}$ NMR shifts were consistent with those reported in the literature. ${ }^{29}$

${ }^{1}$ H NMR (500 MHz, $\left.\mathbf{C D C l}_{3}\right) \delta 4.14-3.81$ (m, 1H), 2.24 (br s, 1H), $1.95-1.78(\mathrm{~m}, 1 \mathrm{H}), 1.73-$ $1.62(\mathrm{~m}, 1 \mathrm{H}), 1.58-1.44(\mathrm{~m}, 1 \mathrm{H})$.

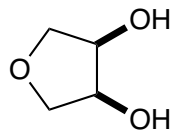

\section{1,4-anhydroerythritol (12)}

Prepared following the general procedure using trans-3,4-tetrahydrofurandiol $(52.1 \mathrm{mg}$, $0.5 \mathrm{mmol}, 1.0$ equiv.), methylboronic acid (37.4 $\mathrm{mg}, 0.625 \mathrm{mmol}, 1.25$ equiv.), diphenyl disulfide (54.5 mg, $0.25 \mathrm{mmol}, 50 \mathrm{~mol} \%$ ), tetrabutylphosphonium decatungstate $(8.5 \mathrm{mg}, 2.5 \mu \mathrm{mol}, 0.5$ $\mathrm{mol} \%$ ) and acetonitrile $(5 \mathrm{~mL})$. After 12 hours of irradiation, the vial was removed, opened to air, and (1S,2S,3R,5S)-(+)-pinanediol (128 mg, $0.75 \mathrm{mmol}, 1.5$ equiv.) and anhydrous $\mathrm{K}_{2} \mathrm{CO}_{3}(345$ mg, $2.5 \mathrm{mmol}, 5$ equiv.) were added. The resulting suspension was rapidly stirred for 24 hours, filtered through a disposable frit and concentrated to remove a majority of the solvent. The residue was purified by flash column chromatography (silica, $0-10 \% \mathrm{MeOH} / \mathrm{DCM}$ ) to provide the title 
compound as light yellow oil (34.0 mg, $0.33 \mathrm{mmol}$, 65\% yield title compound). ${ }^{1} \mathrm{H}$ NMR shifts were consistent with those reported in the literature. ${ }^{29}$

${ }^{1}$ H NMR (500 MHz, CDCl $) \delta 4.36-4.26(\mathrm{~m}, 2 \mathrm{H}), 3.98-3.90(\mathrm{~m}, 2 \mathrm{H}), 3.78-3.70$ (m, 2H), 2.58 (br s, 2H).

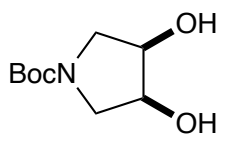

\section{$N$-Boc-cis-3,4-pyrrolidinediol (13)}

Prepared following the general procedure using $N$-Boc-trans-3,4-pyrrolidinediol (101.6 mg, 0.5 mmol, 1.0 equiv.), methylboronic acid (37.4 mg, $0.625 \mathrm{mmol}, 1.25$ equiv.), diphenyl disulfide $(54.5 \mathrm{mg}, 0.25 \mathrm{mmol}, 50 \mathrm{~mol} \%)$, tetrabutylphosphonium decatungstate $(8.5 \mathrm{mg}, 2.5$ $\mu \mathrm{mol}, 0.5 \mathrm{~mol} \%$ ) and acetonitrile $(5 \mathrm{~mL})$. After 12 hours of irradiation, the vial was removed, opened to air, and (1S,2S,3R,5S)-(+)-pinanediol (128 mg, $0.75 \mathrm{mmol}, 1.5$ equiv.) and anhydrous $\mathrm{K}_{2} \mathrm{CO}_{3}$ (345 mg, $2.5 \mathrm{mmol}, 5$ equiv.) were added. The resulting suspension was rapidly stirred for 4 hours, filtered through a disposable frit and concentrated to remove a majority of the solvent. The residue was purified by flash column chromatography ( silica, $0-10 \% \mathrm{MeOH} / \mathrm{DCM}$ ) to provide the title compound as light yellow oil (68.3 mg, $0.34 \mathrm{mmol}, 67 \%$ yield title compound). ${ }^{1} \mathrm{H}$ NMR shifts were consistent with those reported in the literature. ${ }^{30}$

${ }^{1} \mathbf{H}$ NMR (500 MHz, CDCl 3 ) $\delta 4.28-4.16$ (m, 2H), 3.57 (br s, 2H), 3.35 (br s, 2H), 2.68 (br s, $J$ $2 \mathrm{H}), 1.44(\mathrm{~s}, 9 \mathrm{H})$.

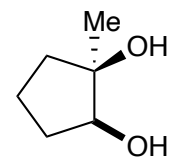

( \pm -cis-1-methylcyclopentane-1,2-diol (14)

Prepared following a modification of the general procedure using (1RS,2RS)-1methylcyclopentane-1,2-diol (58.1 mg, $0.5 \mathrm{mmol}, 1.0$ equiv.), methylboronic acid (37.4 mg, 0.625 
mmol, 1.25 equiv.), diphenyl disulfide (54.5 mg, $0.25 \mathrm{mmol}, 50 \mathrm{~mol} \%)$, tetrabutylphosphonium decatungstate $(8.5 \mathrm{mg}, 2.5 \mu \mathrm{mol}, 0.5 \mathrm{~mol} \%)$ and acetonitrile $(5 \mathrm{~mL})$. After 12 hours of irradiation, the vial was removed, opened to air, and (1S,2S,3R,5S)-(+)-pinanediol (213 mg, $1.25 \mathrm{mmol}, 2.5$ equiv.) and anhydrous $\mathrm{K}_{2} \mathrm{CO}_{3}(345 \mathrm{mg}, 2.5 \mathrm{mmol}, 5$ equiv.) were added. The resulting suspension was rapidly stirred for 24 hours, filtered through a disposable frit and concentrated to remove a majority of the solvent. The residue was purified by flash column chromatography (silica, $0-10 \%$ $\mathrm{MeOH} / \mathrm{DCM})$ to provide the title compound as light yellow oil $(32.5 \mathrm{mg}, 0.28 \mathrm{mmol}, 56 \%$ yield title compound). ${ }^{1} \mathrm{H}$ NMR shifts were consistent with those reported in the literature. ${ }^{31}$

${ }^{1}$ H NMR (500 MHz, CDCl $) \delta 3.70(t, J=6.5 \mathrm{~Hz}, 1 \mathrm{H}), 2.07$ (br s, 2H), $2.02-1.91$ (m, 1H), 1.86 $-1.74(\mathrm{~m}, 2 \mathrm{H}), 1.73-1.63(\mathrm{~m}, 1 \mathrm{H}), 1.63-1.49(\mathrm{~m}, 1 \mathrm{H}), 1.26(\mathrm{~s}, 3 \mathrm{H})$.

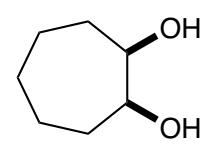

\section{cis-1,2-cycloheptanediol (15)}

Prepared following a modification of the general procedure using trans-1,2cycloheptanediol (65.1 mg, $0.5 \mathrm{mmol}, 1.0$ equiv.), methylboronic acid (37.4 mg, $0.625 \mathrm{mmol}, 1.25$ equiv.), diphenyl disulfide (54.5 mg, $0.25 \mathrm{mmol}, 50 \mathrm{~mol} \%$ ), tetrabutylphosphonium decatungstate (8.5 mg, $2.5 \mu \mathrm{mol}, 0.5 \mathrm{~mol} \%$ ) and acetonitrile (5 mL). Before sparging, $\mathrm{H}_{2} \mathrm{O}$ (315 $\mu \mathrm{L}, 35$ equiv.) was also added to the vial. After 12 hours of irradiation, the vial was removed, opened to air, and (1S,2S,3R,5S)-(+)-pinanediol (128 mg, $0.75 \mathrm{mmol}, 1.5$ equiv.) and anhydrous $\mathrm{K}_{2} \mathrm{CO}_{3}(345 \mathrm{mg}$, $2.5 \mathrm{mmol}, 5$ equiv.) were added. The resulting suspension was rapidly stirred for 4 hours, filtered through a disposable frit and concentrated to remove a majority of the solvent. The residue was purified by flash column chromatography (silica, 0-5\% $\mathrm{MeOH} / \mathrm{DCM}$ ) to provide the title compound as a light yellow oil $\left(50.5 \mathrm{mg}, 0.39 \mathrm{mmol}, 1.6: 1\right.$ ratio of cis to trans isomers by ${ }^{1} \mathrm{H}$ NMR, 77\% combined yield, 47\% yield title compound). ${ }^{1} \mathrm{H}$ NMR shifts were consistent with those reported in the literature. ${ }^{29}$ 


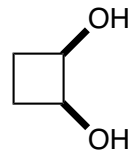

\section{cis-1,2-cyclobutanediol (16)}

Prepared following the general procedure using trans-1,2-cyclobutanediol (44.1 mg, 0.5 mmol, 1.0 equiv.), methylboronic acid (37.4 mg, $0.625 \mathrm{mmol}, 1.25$ equiv.), diphenyl disulfide (54.5 mg, $0.25 \mathrm{mmol}, 50 \mathrm{~mol} \%$ ), tetrabutylphosphonium decatungstate $(8.5 \mathrm{mg}, 2.5 \mu \mathrm{mol}, 0.5$ $\mathrm{mol} \%$ ) and acetonitrile $(5 \mathrm{~mL})$. After 36 hours of irradiation, the vial was removed, opened to air, and mesitylene (14.0 $\mu \mathrm{L}, 0.1 \mathrm{mmol}, 0.2$ equiv.), (1S,2S,3R,5S)-(+)-pinanediol (128 mg, 0.75 mmol, 1.5 equiv.) and anhydrous $\mathrm{K}_{2} \mathrm{CO}_{3}(345 \mathrm{mg}, 2.5 \mathrm{mmol}, 5$ equiv.) were added. The resulting suspension was rapidly stirred for 4 hours, filtered through a disposable frit and concentrated to remove a majority of the solvent. The residue was purified by flash column chromatography (silica, $0-10 \% \mathrm{MeOH} / \mathrm{DCM})$ to provide the title compound as a light yellow oil (14.1 mg, 0.16 mmol, 32\% isolated yield title compound).

${ }^{1}$ H NMR (500 MHz, CD ${ }_{3}$ CN) $\delta 4.17-4.04(\mathrm{~m}, 2 \mathrm{H}), 3.11(\mathrm{~s}, 2 \mathrm{H}), 2.03-1.95(\mathrm{~m}, 2 \mathrm{H}), 1.82-$ $1.71(\mathrm{~m}, 2 \mathrm{H})$.

${ }^{13}$ C NMR (126 MHz, CD $\left.\mathbf{C N}\right) \delta 70.06,27.75$.

IR (film) $v_{\max } 335,2954,1717,1433,1322,1170,1126,977,948,850$

HRMS (EI-TOF) $m / z$ calcd. for $\mathrm{C}_{4} \mathrm{H}_{8} \mathrm{O}_{2}{ }^{+}\left([\mathrm{M}]^{+}\right)$88.05188, found 88.05165

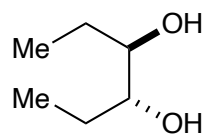

\section{anti-3.4-hexanediol (17)}

Prepared following a modification of the general procedure using syn-3,4-hexanediol (11.8 mg, $0.1 \mathrm{mmol}, 1.0$ equiv.), methylboronic acid ( $7.5 \mathrm{mg}, 0.125 \mathrm{mmol}, 1.25$ equiv.), diphenyl disulfide (10.9 mg, $0.05 \mathrm{mmol}, 50 \mathrm{~mol} \%$ ), tetrabutylphosphonium decatungstate (3.4 mg, 1 $\mu \mathrm{mol}, 1 \mathrm{~mol} \%$ ) and acetonitrile ( $1 \mathrm{~mL})$. After 24 hours of irradiation, the vial was removed, opened to air, and mesitylene (14.0 $\mu \mathrm{L}, 0.1 \mathrm{mmol}, 1$ equiv.), (1S,2S,3R,5S)-(+)-pinanediol (128 
mg, 0.75 mmol, 1.5 equiv.) and anhydrous $\mathrm{K}_{2} \mathrm{CO}_{3}$ (345 mg, $2.5 \mathrm{mmol}, 5$ equiv.) were added. The resulting suspension was rapidly stirred overnight. This reaction setup was replicated five times to reach a combined $0.5 \mathrm{mmol}$ scale procedure. All five reactions were combined and filtered through a disposable frit, and a majority of the remaining solvent was removed by concentration under vacuum, and the residue was purified by flash column chromatography (silica, 0-5\% $\mathrm{MeOH} / \mathrm{DCM})$ to provide the title compound as a yellow oil (45.5 mg, 0.39 mmol, 8.5:1 anti/syn ratio, 77\% combined yield, $69 \%$ isolated yield title compound). ${ }^{1} \mathrm{H}$ NMR shifts were consistent with those reported in the literature for both isomers. ${ }^{13}$

1H NMR (400 MHz, CDCI3) $\delta 3.50-3.29(\mathrm{~m}, 2 \mathrm{H}), 1.95$ (s, 2H), $1.72-1.34(\mathrm{~m}, 4 \mathrm{H}), 0.99(\mathrm{t}, J$ $=7.4 \mathrm{~Hz}, 6 \mathrm{H})$.

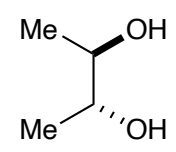

\section{anti-2,3-butanediol (18)}

Prepared following a modification of the general procedure using equal amounts of synand anti-2,3-butanediol (4.5 $\mathrm{mg}$ each isomer, $0.05 \mathrm{mmol}, 0.5$ equiv.) for $0.1 \mathrm{mmol}$ total, 1 equiv.), methylboronic acid (7.5 mg, $0.125 \mathrm{mmol}, 1.25$ equiv.), diphenyl disulfide (10.9 $\mathrm{mg}, 0.05$ mmol, $50 \mathrm{~mol} \%)$, tetrabutylphosphonium decatungstate $(3.4 \mathrm{mg}, 1 \mu \mathrm{mol}, 1 \mathrm{~mol} \%)$ and acetonitrile $(1 \mathrm{~mL})$. After 24 hours of irradiation, the vial was removed, opened to air, and mesitylene (14.0 $\mu \mathrm{L}, 0.1 \mathrm{mmol}, 1$ equiv.) (1S,2S,3R,5S)-(+)-pinanediol (128 mg, $0.75 \mathrm{mmol}$, 1.5 equiv.) and anhydrous $\mathrm{K}_{2} \mathrm{CO}_{3}(345 \mathrm{mg}, 2.5 \mathrm{mmol}, 5$ equiv.) were added. The resulting suspension was rapidly stirred overnight, and an aliquot was removed and analyzed by ${ }^{1} \mathrm{H}$ NMR $\left(\mathrm{CD}_{3} \mathrm{CN}\right)$ to determine an analytical yield (83\% combined yield, $75 \%$ anti isomer, $7.6 \%$ syn isomer, 10.0:1 dr). This reaction setup was replicated five times to reach a combined $0.5 \mathrm{mmol}$ scale procedure. All five reactions were combined and filtered through a disposable frit, and a majority of the remaining solvent was removed by concentration under vacuum, and the residue was purified by flash column chromatography (silica, 0-5\% $\mathrm{MeOH} / \mathrm{DCM}$ ) to provide the title compound as a yellow oil (23.9 mg, $0.26 \mathrm{mmol}, 10.9: 1$ anti/syn ratio, 53\% combined yield, 49\% 
isolated yield title compound). ${ }^{1} \mathrm{H}$ NMR shifts were consistent with commercial samples of both isomers.

${ }^{1}$ H NMR (400 MHz, CDCl $) \delta 3.46(\mathrm{qd}, J=4.3,2.5 \mathrm{~Hz}, 2 \mathrm{H}), 1.13-1.10(\mathrm{~m}, 6 \mathrm{H})$.

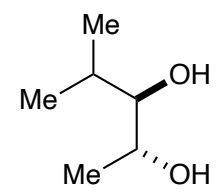

( \pm )-anti-4-methyl-2,3-pentanediol (19)

Prepared following a modification of the general procedure using equal amounts of synand anti-4-methyl-2,3-pentanediol (5.9 mg each isomer, $0.05 \mathrm{mmol}, 0.5$ equiv. for $0.1 \mathrm{mmol}$ total, 1 equiv.), methylboronic acid ( $7.5 \mathrm{mg}, 0.125 \mathrm{mmol}, 1.25$ equiv.), diphenyl disulfide (10.9 $\mathrm{mg}, 0.05 \mathrm{mmol}, 50 \mathrm{~mol} \%)$, tetrabutylphosphonium decatungstate $(3.4 \mathrm{mg}, 1 \mu \mathrm{mol}, 1 \mathrm{~mol} \%)$ and acetonitrile $(1 \mathrm{~mL})$. After 24 hours of irradiation, the vial was removed, opened to air, and mesitylene (14.0 $\mu \mathrm{L}, 0.1 \mathrm{mmol}, 1$ equiv.) (1S,2S,3R,5S)-(+)-pinanediol (128 mg, $0.75 \mathrm{mmol}$, 1.5 equiv.) and anhydrous $\mathrm{K}_{2} \mathrm{CO}_{3}(345 \mathrm{mg}, 2.5 \mathrm{mmol}, 5$ equiv.) were added. The resulting suspension was rapidly stirred overnight, and an aliquot was removed and analyzed by ${ }^{1} \mathrm{H}$ NMR $\left(\mathrm{CD}_{3} \mathrm{CN}\right)$ to determine an analytical yield (92\% combined yield, $86 \%$ anti isomer, $6 \% \mathrm{syn}$ isomer, 14.5:1 anti/syn ratio). This reaction setup was replicated five times to reach a combined $0.5 \mathrm{mmol}$ scale procedure. All five reactions were combined and filtered through a disposable frit, and a majority of the remaining solvent was removed by concentration under vacuum, and the residue was purified by flash column chromatography (silica, 0-5\% $\mathrm{MeOH} / \mathrm{DCM}$ ) to provide the title compound as a yellow oil $(43.5 \mathrm{mg}, 0.37 \mathrm{mmol}, 11.7: 1 \mathrm{anti} / \mathrm{syn}$ ratio, $74 \%$ combined yield, 68\% isolated yield title compound). ${ }^{1} \mathrm{H}$ NMR shifts were consistent with those reported in the literature for both isomers. ${ }^{14}$

${ }^{1}$ H NMR (500 MHz, CDCl $) \delta 3.81(\mathrm{p}, J=6.2 \mathrm{~Hz}, 1 \mathrm{H}), 3.14(\mathrm{dd}, J=5.9,4.7 \mathrm{~Hz}, 1 \mathrm{H}), 1.88-$ $1.77(\mathrm{~m}, 1 \mathrm{H}), 1.23(\mathrm{~d}, J=6.3 \mathrm{~Hz}, 3 \mathrm{H}), 1.02(\mathrm{~d}, J=6.9 \mathrm{~Hz}, 3 \mathrm{H}), 0.94(\mathrm{~d}, J=6.8 \mathrm{~Hz}, 3 \mathrm{H})$. 


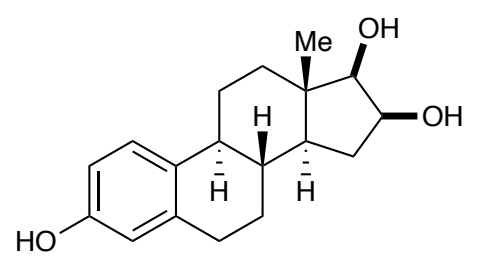

\section{6ק-epiestriol (20)}

Prepared following a modification of the general procedure using estriol (144.2 $\mathrm{mg}, 0.5$ mmol, 1.0 equiv.), methylboronic acid (37.4 mg, $0.625 \mathrm{mmol}, 1.25$ equiv.), diphenyl disulfide (54.5 mg, $0.25 \mathrm{mmol}, 50 \mathrm{~mol} \%$ ), tetrabutylphosphonium decatungstate (33.9 mg, $10 \mu \mathrm{mol}, 2$ mol\%) and 4:1 acetonitrile/anhydrous $t$ - $\mathrm{BuOH}(25 \mathrm{~mL}, 0.02 \mathrm{M})$. The solution was also sparged for 25 minutes, rather than 15 minutes. After 36 hours of irradiation, the vial was removed, opened to air, and (1S,2S,3R,5S)-(+)-pinanediol (128 mg, $0.75 \mathrm{mmol}, 1.5$ equiv.) was added. The resulting suspension was rapidly stirred for 24 hours, filtered through a disposable frit and concentrated to remove a majority of the solvent. The residue was dispersed on silica gel and purified by flash column chromatography ( ilica, dry load, $0-5 \% \mathrm{MeOH} / \mathrm{DCM}$ ) to provide the title compound as a white solid (53.0 mg, $0.18 \mathrm{mmol}, 37 \%$ yield title compound, with $1 \mathrm{wt} \% \mathrm{MeOH}$ ).

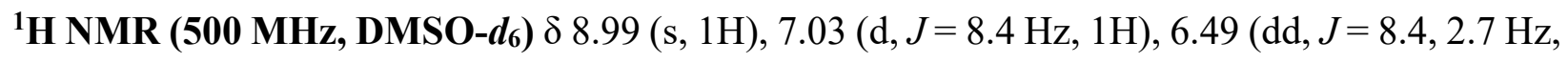
$1 \mathrm{H}), 6.42(\mathrm{~d}, J=2.6 \mathrm{~Hz}, 1 \mathrm{H}), 4.55(\mathrm{~d}, J=3.9 \mathrm{~Hz}, 1 \mathrm{H}), 4.14(\mathrm{~d}, J=7.2 \mathrm{~Hz}, 1 \mathrm{H}), 4.00-3.93(\mathrm{~m}$, $1 \mathrm{H}), 3.24(\mathrm{t}, J=7.4 \mathrm{~Hz}, 1 \mathrm{H}), 3.16(\mathrm{~d}, J=5.2 \mathrm{~Hz}, 0 \mathrm{H}), 2.82-2.61(\mathrm{~m}, 2 \mathrm{H}), 2.27-2.19(\mathrm{~m}, 1 \mathrm{H})$, $2.17-2.02(\mathrm{~m}, 2 \mathrm{H}), 1.85-1.74(\mathrm{~m}, 2 \mathrm{H}), 1.39-1.09(\mathrm{~m}, 5 \mathrm{H}), 0.99-0.89(\mathrm{~m}, 1 \mathrm{H}), 0.73(\mathrm{~s}, 3 \mathrm{H})$.

${ }^{13}$ C NMR (126 MHz, DMSO-d6) $\delta 155.37,137.57,130.85,126.46,115.37,113.18,80.53,69.11$, $46.47,44.14,42.79,38.53,37.64,35.17,29.61,27.58,26.30,12.71$.

IR (film) $v_{\max } 3472,3181,2921,1619,1583,1496,1288,1133$ 1074, 933, 909, 881, 785

HRMS (ESI-TOF) $\mathrm{m} / \mathrm{z}$ calcd. for $\mathrm{C}_{18} \mathrm{H}_{23} \mathrm{O}_{3}\left([\mathrm{M}-\mathrm{H}]^{-}\right)$288.16527, found 288.16588 


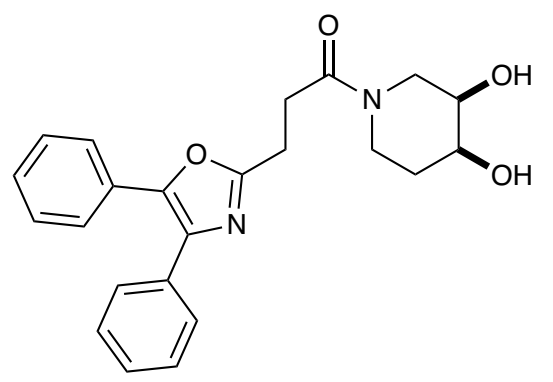

\section{( \pm )-1-(cis-3,4-dihydroxypiperidin-1-yl)-3-(4,5-diphenyloxazol-2-yl)propan-1-one (21)}

Prepared following a modification of the general procedure using $( \pm)-1-(\operatorname{trans}-3,4-$ dihydroxypiperidin-1-yl)-3-(4,5-diphenyloxazol-2-yl)propan-1-one (196.2 mg, $0.5 \mathrm{mmol}, 1.0$ equiv.), methylboronic acid (37.4 mg, $0.625 \mathrm{mmol}, 1.25$ equiv.), diphenyl disulfide (54.5 $\mathrm{mg}, 0.25$ mmol, $50 \mathrm{~mol} \%$ ), tetrabutylphosphonium decatungstate (16.9 $\mathrm{mg}, 5 \mu \mathrm{mol}, 1 \mathrm{~mol} \%$ ) and acetonitrile $(5 \mathrm{~mL})$. After 12 hours of irradiation, the vial was removed, opened to air, and (1S,2S,3R,5S)-(+)-pinanediol (128 mg, $0.75 \mathrm{mmol}, 1.5$ equiv.) and anhydrous $\mathrm{K}_{2} \mathrm{CO}_{3}(345 \mathrm{mg}$, $2.5 \mathrm{mmol}, 5$ equiv.) were added. The resulting suspension was rapidly stirred for 4 hours, filtered through a disposable frit and concentrated to remove a majority of the solvent. The residue was purified by flash column chromatography (silica, $0-10 \% \mathrm{MeOH} / \mathrm{DCM}$ ) to provide the title compound as a light yellow solid ( $99.5 \mathrm{mg}, 0.25 \mathrm{mmol}, 51 \%$ yield title compound).

${ }^{1}$ H NMR (500 MHz, DMSO) $\delta 7.61$ - 7.51 (m, 4H), 7.48 - 7.33 (m, 6H), 4.55 (s, 1H), 4.48 - 4.37 (m, 1H), $3.79-3.55(\mathrm{~m}, 3 \mathrm{H}), 3.49-3.27(\mathrm{~m}, 3 \mathrm{H}), 3.13-3.00(\mathrm{~m}, 2 \mathrm{H}), 2.90(\mathrm{~m}, 2 \mathrm{H}), 1.90-1.38$ $(\mathrm{m}, 2 \mathrm{H})$. Presence of rotamers confirmed by high-temperature NMR.

${ }^{13}$ C NMR (126 MHz, DMSO) $\delta$ 169.22, 168.98, 163.10, 163.05, 144.42, 134.35, 132.11, 128.99, $128.78,128.69$, 128.52, 128.16, 127.42, 126.34, 71.34, 70.46, 69.84, 69.58, 48.08, 45.46, 42.46, $38.19,31.81,29.86,28.99,28.89,23.29,23.26$.

IR (film) $v_{\max }$ 3340, 2923, 1620, 1443, 1216, 1060, 963, 753, 692, 674

HRMS (ESI-TOF) $m / z$ calcd. for $\mathrm{C}_{23} \mathrm{H}_{25} \mathrm{~N}_{2} \mathrm{O}_{4}{ }^{+}\left([\mathrm{M}+\mathrm{H}]^{+}\right) 393.18088$, found 393.18153 .

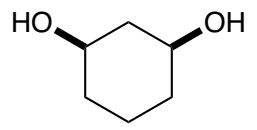




\section{cis-1,3-cyclohexanediol (22)}

Prepared following the general procedure using trans-1,3-cyclohexanediol $(58.1 \mathrm{mg}, 0.5$ mmol, 1.0 equiv.), methylboronic acid (37.4 mg, $0.625 \mathrm{mmol}, 1.25$ equiv.), diphenyl disulfide (54.5 mg, $0.25 \mathrm{mmol}, 50 \mathrm{~mol} \%$ ), tetrabutylphosphonium decatungstate $(8.5 \mathrm{mg}, 2.5 \mu \mathrm{mol}, 0.5$ mol\%) and acetonitrile ( $5 \mathrm{~mL})$. After 12 hours of irradiation, the vial was removed, opened to air, and (1S,2S,3R,5S)-(+)-pinanediol (128 mg, $0.75 \mathrm{mmol}, 1.5$ equiv.) and anhydrous $\mathrm{K}_{2} \mathrm{CO}_{3}(345$ mg, 2.5 mmol, 5 equiv.) were added. The resulting suspension was rapidly stirred for 4 hours, filtered through a disposable frit and concentrated to remove a majority of the solvent. The residue was purified by flash column chromatography (silica, $0-10 \% \mathrm{MeOH} / \mathrm{DCM}$ ) to provide the title compound as a light-yellow solid (46.7 mg, $0.40 \mathrm{mmol}, 80 \%$ yield title compound). ${ }^{1} \mathrm{H}$ NMR shifts were consistent with those reported in the literature. ${ }^{32}$

${ }^{1}$ H NMR (500 MHz, CDCl $) \delta 3.82(\mathrm{tt}, J=7.8,3.6 \mathrm{~Hz}, 2 \mathrm{H}), 2.04$ (d, $\left.J=12.8 \mathrm{~Hz}, 1 \mathrm{H}\right), 1.94$ (br $\mathrm{s}, 2 \mathrm{H}), 1.93-1.84(\mathrm{~m}, 1 \mathrm{H}), 1.82-1.75(\mathrm{~m}, 2 \mathrm{H}), 1.65-1.54(\mathrm{~m}, 1 \mathrm{H}), 1.53-1.39(\mathrm{~m}, 2 \mathrm{H}), 1.38-$ $1.26(\mathrm{~m}, 1 \mathrm{H})$.

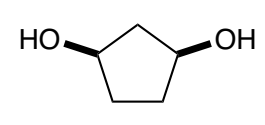

\section{cis-1,3-cyclopentanediol (23)}

Prepared following the general procedure using trans-1,3-cyclopentanol $(51.1 \mathrm{mg}, 0.5$ mmol, 1.0 equiv.), methylboronic acid (37.4 mg, $0.625 \mathrm{mmol}, 1.25$ equiv.), diphenyl disulfide (54.5 mg, $0.25 \mathrm{mmol}, 50 \mathrm{~mol} \%$ ), tetrabutylphosphonium decatungstate $(8.5 \mathrm{mg}, 2.5 \mu \mathrm{mol}, 0.5$ mol\%) and acetonitrile ( $5 \mathrm{~mL})$. After 12 hours of irradiation, the vial was removed, opened to air, and (1S,2S,3R,5S)-(+)-pinanediol (128 mg, 0.75 mmol, 1.5 equiv.) and anhydrous $\mathrm{K}_{2} \mathrm{CO}_{3}(345$ mg, 2.5 mmol, 5 equiv.) were added. The resulting suspension was rapidly stirred for 4 hours, filtered through a disposable frit and concentrated to remove a majority of the solvent. The residue was purified by flash column chromatography (silica, 0-10\% $\mathrm{MeOH} / \mathrm{DCM}$ ) to provide the title compound as a light yellow oil (24.1 mg, $0.24 \mathrm{mmol}, 48 \%$ yield title compound). $10 \%$ of the trans isomer was also detected in ${ }^{1} \mathrm{H}$ NMR of the crude reaction mixture, and could be separated 
chromatagraphically. (Combined yield 58\%, ${ }^{1} \mathrm{H}$ NMR shifts were consistent with those reported in the literature. ${ }^{33}$

${ }^{1}$ H NMR (500 MHz, CDCl $)_{3} \delta 4.41-4.37$ (m, 2H), 2.13 (br s, 2H), 1.95 - 1.87 (m, 5H), 1.77 (dt, $J=14.3,5.0 \mathrm{~Hz}, 1 \mathrm{H})$.

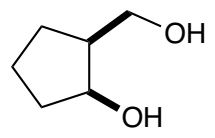

( \pm )-cis-2-(hydroxymethyl)cyclopentanol (24)

Prepared following the general procedure using trans-2-(hydroxymethyl)cyclopentanol (58.1 mg, $0.5 \mathrm{mmol}, 1.0$ equiv.), methylboronic acid (37.4 mg, $0.625 \mathrm{mmol}, 1.25$ equiv.), diphenyl disulfide (54.5 mg, $0.25 \mathrm{mmol}, 50 \mathrm{~mol} \%$ ), tetrabutylphosphonium decatungstate $(8.5 \mathrm{mg}, 2.5$ $\mu \mathrm{mol}, 0.5 \mathrm{~mol} \%)$ and acetonitrile $(5 \mathrm{~mL})$. After 24 hours of irradiation, the vial was removed, opened to air, and (1S,2S,3R,5S)-(+)-pinanediol (128 mg, $0.75 \mathrm{mmol}, 1.5$ equiv.) and anhydrous $\mathrm{K}_{2} \mathrm{CO}_{3}$ (345 mg, $2.5 \mathrm{mmol}, 5$ equiv.) were added. The resulting suspension was rapidly stirred for 20 hours, filtered through a disposable frit and concentrated to remove a majority of the solvent. The residue was purified by flash column chromatography (silica, 0-10\% $\mathrm{MeOH} / \mathrm{DCM}$ ) to provide the title compound as a thick clear oil that solidified upon standing $(35.7 \mathrm{mg}, 0.31 \mathrm{mmol}, 62 \%$ yield title compound). Remaining starting material could be separated chromatagraphically as well (8.9 mg, $0.07 \mathrm{mmol}, 15 \%$ ), for a combined yield of $77 \%$ and a dr of 4.0:1. ${ }^{1} \mathrm{H}$ NMR shifts were consistent with those reported in the literature. ${ }^{34}$

${ }^{1}$ H NMR (500 MHz, CDCl $)$ ) $\delta 4.41(\mathrm{td}, J=5.3,3.2 \mathrm{~Hz}, 1 \mathrm{H}), 3.85(\mathrm{dd}, J=11.0,4.3 \mathrm{~Hz}, 1 \mathrm{H}), 3.78$ $(\mathrm{dd}, J=10.9,7.7 \mathrm{~Hz}, 1 \mathrm{H}), 2.20$ (br fs, $2 \mathrm{H}), 2.11-2.02(\mathrm{~m}, 1 \mathrm{H}), 1.94-1.75(\mathrm{~m}, 2 \mathrm{H}), 1.74-1.50$ $(\mathrm{m}, 4 \mathrm{H})$.

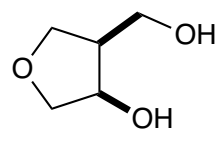

( \pm )-cis-3-hydroxy-4-(hydroxymethyl)tetrahydrofuran (25) 
Prepared following the general procedure using $N$-Boc-trans-3-hydroxy-4(hydroxymethyl)tetrahydrofuran (59.1 mg, $0.5 \mathrm{mmol}, 1.0$ equiv.), methylboronic acid (37.4 $\mathrm{mg}$, $0.625 \mathrm{mmol}, 1.25$ equiv.), diphenyl disulfide (54.5 mg, $0.25 \mathrm{mmol}, 50 \mathrm{~mol} \%$ ), tetrabutylphosphonium decatungstate $(8.5 \mathrm{mg}, 2.5 \mu \mathrm{mol}, 1 \mathrm{~mol} \%)$ and acetonitrile $(5 \mathrm{~mL})$. After 24 hours of irradiation, the vial was removed, opened to air, and (1S,2S,3R,5S)-(+)-pinanediol (128 mg, $0.75 \mathrm{mmol}, 1.5$ equiv.) and anhydrous $\mathrm{K}_{2} \mathrm{CO}_{3}(345 \mathrm{mg}, 2.5 \mathrm{mmol}, 5$ equiv.) were added. The resulting suspension was rapidly stirred for 4 hours, filtered through a disposable frit and concentrated to remove a majority of the solvent. The residue was purified by flash column chromatography (silica, $0-10 \% \mathrm{MeOH} / \mathrm{DCM}$ ) to provide the title compound as a thick clear oil that solidified upon standing $(29.2 \mathrm{mg}, 0.24 \mathrm{mmol}, 48 \%$ yield title compound, with $<5 \%$ tetrabutylphosphonium salt impurity).

${ }^{1}$ H NMR (400 MHz, CD $\mathbf{3}$ CN) $\delta 4.34$ (br s, 1H), $3.85-3.77$ (m, 2H), $3.73(\mathrm{dd}, J=10.9,7.1 \mathrm{~Hz}$, $1 \mathrm{H}), 3.66-3.52$ (m, 3H), 3.13 (br s, $J=4.0 \mathrm{~Hz}, 1 \mathrm{H}), 2.81$ (br s, $1 \mathrm{H}), 2.42-2.25$ (m, 1H).

${ }^{13}$ C NMR (126 MHz, CD 3 CN) $\delta$ 76.22, 72.65, 69.20, 59.67, 46.78

IR (film) $v_{\max } 3334,2875,1661,1316,1213,1053,1024,974,900,870$

HRMS (EI-TOF) $\mathrm{m} / z$ calcd. for $\mathrm{C}_{5} \mathrm{H}_{10} \mathrm{O}_{3}{ }^{+}\left([\mathrm{M}]^{+}\right) 118.06245$, found 118.06213

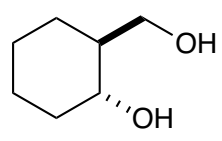

\section{$(1 R, 2 S)$-2-(hydroxymethyl)cyclohexanol (26)}

Prepared following a modification of the general procedure using (1S,2S)-2(hydroxymethyl)cyclohexanol (65.1 mg, $0.5 \mathrm{mmol}, 1.0$ equiv.), methylboronic acid (37.4 mg, $0.625 \mathrm{mmol}, 1.25$ equiv.), diphenyl disulfide (54.5 $\mathrm{mg}, \quad 0.25 \mathrm{mmol}, 50 \mathrm{~mol} \%$ ), tetrabutylphosphonium decatungstate $(16.9 \mathrm{mg}, 5 \mu \mathrm{mol}, 1 \mathrm{~mol} \%)$ and acetonitrile $(5 \mathrm{~mL})$. After 24 hours of irradiation, the vial was removed, opened to air, and (1S,2S,3R,5S)-(+)-pinanediol (128 mg, $0.75 \mathrm{mmol}, 1.5$ equiv.) and anhydrous $\mathrm{K}_{2} \mathrm{CO}_{3}$ (345 mg, $2.5 \mathrm{mmol}, 5$ equiv.) were added. The resulting suspension was rapidly stirred for 18 hours, filtered through a disposable frit and concentrated to remove a majority of the solvent. The residue was purified by flash column chromatography (silica, $0-10 \% \mathrm{MeOH} / \mathrm{DCM}$ ) to provide the title compound as a light yellow oil 
(58.1 mg, $0.45 \mathrm{mmol}, 13.0: 1$ ratio of trans to cis diastereomers by ${ }^{1} \mathrm{H}$ NMR, $70 \%$ ee of trans diastereomer, $83 \%$ yield title compound, $89 \%$ combined yield). Enantiomeric excess and absolute configuration were determined by chiral HPLC of the bis-benzoyl protected diol (Chiralcel OJ, IPA/hexanes) and comparison to independently-synthesized samples of both enantiomers. ${ }^{1} \mathrm{H}$ NMR shifts were consistent with those reported in the literature. ${ }^{16}$

${ }^{1}$ H NMR (500 MHz, $\left.\mathbf{C D C l}_{3}\right) \delta 3.72-3.62(\mathrm{~m}, 2 \mathrm{H}), 3.50(\mathrm{ddd}, J=10.7,9.3,4.4 \mathrm{~Hz}, 1 \mathrm{H}), 2.63(\mathrm{~s}$, $3 \mathrm{H}), 1.98-1.90(\mathrm{~m}, 1 \mathrm{H}), 1.75(\mathrm{ddt}, J=9.1,6.4,3.1 \mathrm{~Hz}, 1 \mathrm{H}), 1.67(\mathrm{dtt}, J=6.6,5.1,2.4 \mathrm{~Hz}, 1 \mathrm{H})$, $1.63-1.50(\mathrm{~m}, 2 \mathrm{H}), 1.36-1.14(\mathrm{~m}, 2 \mathrm{H}), 0.90(\mathrm{tdd}, J=12.6,9.6,3.7 \mathrm{~Hz}, 1 \mathrm{H})$.

\section{Chiral HPLC:}

Bis-benzoylated product:

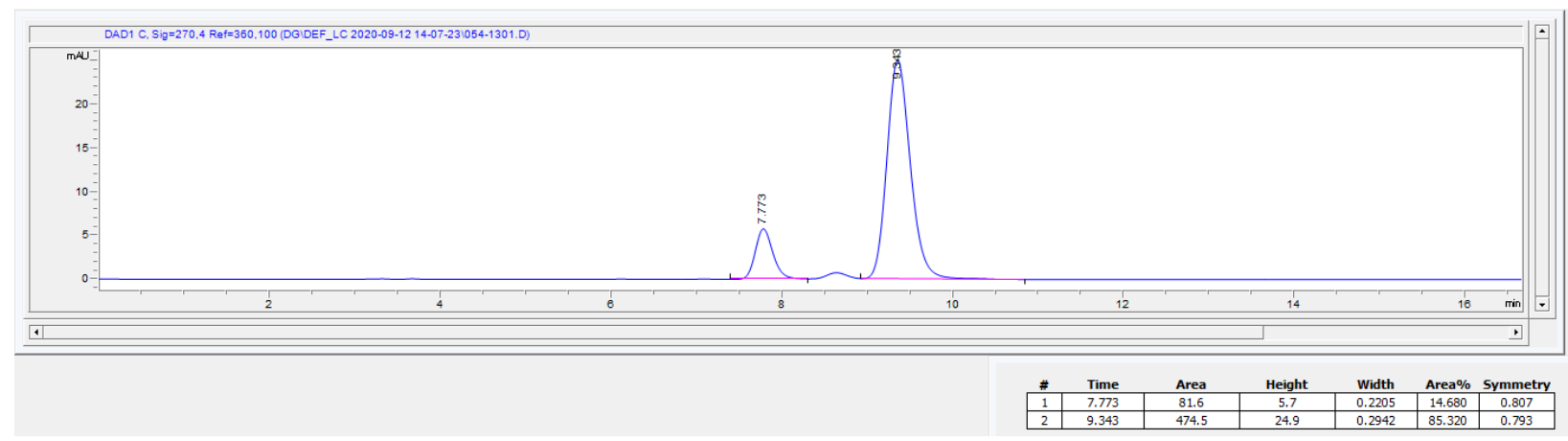

Racemic trans diastereomer:

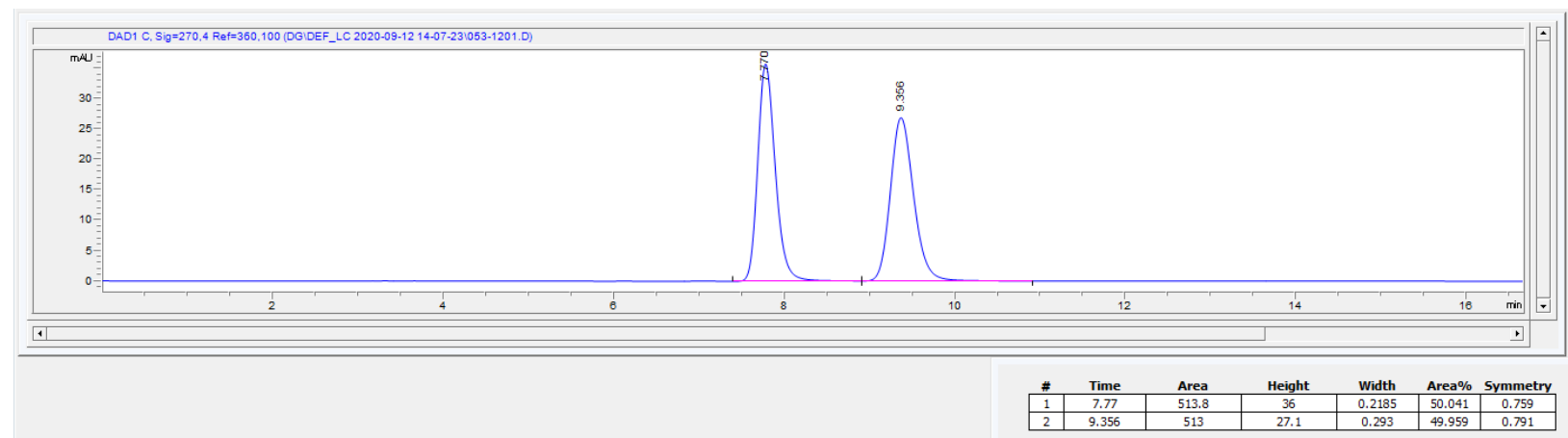<smiles>O=C(CO)C1CCN(C(=O)O)CC1O</smiles> 


\section{( \pm )-N-Boc-trans-3-hydroxy-4-(hydroxymethyl)piperidine (27)}

Prepared following the general procedure using N-Boc-trans-3-hydroxy-4(hydroxymethyl)piperidine (115.6 mg, $0.5 \mathrm{mmol}, 1.0$ equiv.), methylboronic acid (37.4 mg, 0.625 mmol, 1.25 equiv.), diphenyl disulfide (54.5 mg, $0.25 \mathrm{mmol}, 50 \mathrm{~mol} \%$ ), tetrabutylphosphonium decatungstate $(8.5 \mathrm{mg}, 2.5 \mu \mathrm{mol}, 0.5 \mathrm{~mol} \%)$ and acetonitrile $(5 \mathrm{~mL})$. After 24 hours of irradiation, the vial was removed, opened to air, and (1S,2S,3R,5S)-(+)-pinanediol (128 mg, $0.75 \mathrm{mmol}, 1.5$ equiv.) and anhydrous $\mathrm{K}_{2} \mathrm{CO}_{3}$ (345 mg, $2.5 \mathrm{mmol}$, 5 equiv.) were added. The resulting suspension was rapidly stirred for 4 hours, filtered through a disposable frit and concentrated to remove a majority of the solvent. The residue was purified by flash column chromatography (silica, $0-10 \%$ $\mathrm{MeOH} / \mathrm{DCM}$ ) to provide the title compound as a thick clear oil that solidified upon standing (73.8 $\mathrm{mg}, 0.32 \mathrm{mmol}, 64 \%$ yield title compound). A small amount of starting material was also isolated (7.2 mg, $0.03 \mathrm{mmol}, 6 \%$ ) for a combined yield of isomers of $70 \%$ and a dr of $10.3: 1 .{ }^{1} \mathrm{H}$ NMR shifts were consistent with those reported in the literature. ${ }^{17 a}$

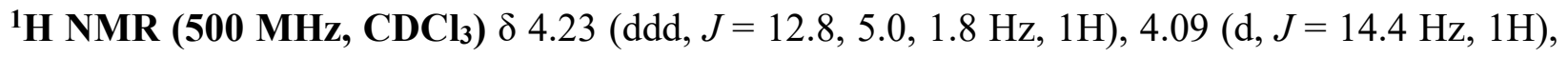
$3.79(\mathrm{dd}, J=10.5,3.9 \mathrm{~Hz}, 1 \mathrm{H}), 3.70(\mathrm{dd}, J=10.5,8.8 \mathrm{~Hz}, 1 \mathrm{H}), 3.55(\mathrm{td}, J=10.0,5.0 \mathrm{~Hz}, 1 \mathrm{H})$, $2.66(\mathrm{td}, J=13.0,2.9 \mathrm{~Hz}, 1 \mathrm{H}), 2.53(\mathrm{dd}, J=12.8,10.4 \mathrm{~Hz}, 1 \mathrm{H}), 2.29$ (br s, 2H), 1.69 (dtt, $J=12.9$, 8.8, $3.9 \mathrm{~Hz}, 1 \mathrm{H}), 1.56(\mathrm{dq}, J=13.4,2.9 \mathrm{~Hz}, 1 \mathrm{H}), 1.45(\mathrm{~s}, 9 \mathrm{H}), 1.14(\mathrm{qd}, J=12.8,4.7 \mathrm{~Hz}, 1 \mathrm{H})$.

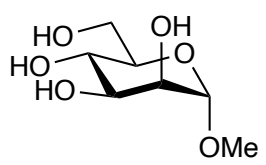

\section{D- $\alpha$-methylmannose (28)}

Prepared following a modification of the general procedure using D- $\alpha$-methylglucose $(97.1$ mg, 0.5 mmol, 1.0 equiv.), methylboronic acid (104.8 mg, $1.75 \mathrm{mmol}, 3.5$ equiv.), diphenyl disulfide (54.5 mg, $0.25 \mathrm{mmol}, 50 \mathrm{~mol} \%$ ), tetrabutylphosphonium decatungstate $(33.9 \mathrm{mg}, 10$ $\mu \mathrm{mol}, 2 \mathrm{~mol} \%)$ and acetonitrile $(25 \mathrm{~mL}, 0.02 \mathrm{M})$. The solution was also sparged for 25 minutes while stirring, rather than 15 minutes. After 24 hours of irradiation, the vial was removed, opened to air, and mesitylene (14.0 $\mu \mathrm{L}, 1 \mathrm{mmol}, 0.2$ equiv.) and (1S,2S,3R,5S)-(+)-pinanediol (340 mg, 2 mmol, 4 equiv.) was added. The resulting solution was rapidly stirred for 4 hours, and an aliquot 
was removed and analyzed by ${ }^{1} \mathrm{H} \mathrm{NMR}\left(\mathrm{CD}_{3} \mathrm{CN}\right)$ to determine an analytical yield (47\% analytical yield). The solution was then filtered through a disposable frit and concentrated to remove a majority of the solvent. The residue was dispersed on silica and purified by flash column chromatography (silica, dry load, 5:4:1 $\mathrm{MeCN} / \mathrm{EtOAc} / \mathrm{H}_{2} \mathrm{O}$ ) to provide the title compound as an off-white solid (38.4 mg, $0.20 \mathrm{mmol}$, 40\% yield title compound). ${ }^{1} \mathrm{H}$ NMR shifts were consistent with a commercially obtained sample.

${ }^{1}$ H NMR (500 MHz, CD $\left.\mathbf{3 O D}\right) \delta 4.63(\mathrm{~d}, \mathrm{~J}=1.7 \mathrm{~Hz}, 1 \mathrm{H}), 3.84(\mathrm{dd}, \mathrm{J}=11.7,2.4 \mathrm{~Hz}, 1 \mathrm{H}), 3.77$ $(\mathrm{dd}, \mathrm{J}=3.3,1.7 \mathrm{~Hz}, 1 \mathrm{H}), 3.70(\mathrm{dd}, \mathrm{J}=11.8,6.0 \mathrm{~Hz}, 1 \mathrm{H}), 3.65(\mathrm{dd}, \mathrm{J}=9.4,3.4 \mathrm{~Hz}, 1 \mathrm{H}), 3.59$ (t, J $=9.5 \mathrm{~Hz}, 1 \mathrm{H}), 3.48(\mathrm{ddd}, \mathrm{J}=9.7,6.0,2.3 \mathrm{~Hz}, 1 \mathrm{H}), 3.38(\mathrm{~s}, 3 \mathrm{H})$.

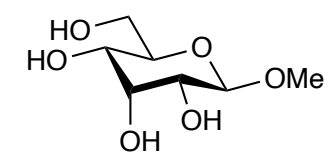

\section{D- $\beta$-methylallose (29)}

Prepared following a modification of the general procedure using D- $\beta$-methylglucose $(97.1$ mg, 0.5 mmol, 1.0 equiv.), methylboronic acid (104.8 mg, $1.75 \mathrm{mmol}, 3.5$ equiv.), diphenyl disulfide (54.5 mg, $0.25 \mathrm{mmol}, 50 \mathrm{~mol} \%$ ), tetrabutylphosphonium decatungstate (33.9 $\mathrm{mg}, 10$ $\mu \mathrm{mol}, 2 \mathrm{~mol} \%)$ and acetonitrile $(25 \mathrm{~mL}, 0.02 \mathrm{M})$. The solution was also sparged for 25 minutes while stirring, rather than 15 minutes. After 8 hours of irradiation, the vial was removed, opened to air, and (1S,2S,3R,5S)-(+)-pinanediol (340 mg, $0.75 \mathrm{mmol}, 4$ equiv.) was added. The resulting solution was rapidly stirred for 4 hours, filtered through a disposable frit and concentrated to remove a majority of the solvent. The residue was dispersed on silica and purified by flash column chromatography (silica, dry load, 5:4:1 $\mathrm{MeCN} / \mathrm{EtOAc} / \mathrm{H}_{2} \mathrm{O}$ ) to provide the title compound as an off-white solid (60.3 mg, $0.31 \mathrm{mmol}, 62 \%$ yield title compound). ${ }^{1} \mathrm{H}$ NMR shifts were consistent with those reported in the literature. ${ }^{35}$

${ }^{1}$ H NMR (400 MHz, CD 3 OD) $\delta 4.52(\mathrm{~d}, J=7.9 \mathrm{~Hz}, 1 \mathrm{H}), 4.03(\mathrm{t}, J=3.0 \mathrm{~Hz}, 1 \mathrm{H}), 3.88-3.81(\mathrm{~m}$, 1H), $3.72-3.62(\mathrm{~m}, 2 \mathrm{H}), 3.52(\mathrm{~s}, 3 \mathrm{H}), 3.47(\mathrm{dd}, J=9.5,3.0 \mathrm{~Hz}, 1 \mathrm{H}), 3.28(\mathrm{dd}, J=8.0,3.1 \mathrm{~Hz}$, $1 \mathrm{H})$. 


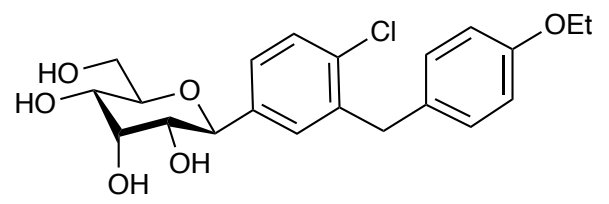

\section{allo-dapagliflozin (30)}

Prepared following a modification of the general procedure using dapagliflozin (204.4 mg, $0.5 \mathrm{mmol}, 1.0$ eq.), methylboronic acid ( $89.8 \mathrm{mg}, 1.5 \mathrm{mmol}, 3$ equiv.), diphenyl disulfide (54.5 $\mathrm{mg}, 0.25 \mathrm{mmol}, 50 \mathrm{~mol} \%)$, tetrabutylphosphonium decatungstate $(8.5 \mathrm{mg}, 2.5 \mu \mathrm{mol}, 0.5 \mathrm{~mol} \%)$ and acetonitrile $(25 \mathrm{~mL}, 0.02 \mathrm{M})$. The solution was also sparged for 25 minutes while stirring, rather than 15 minutes. After 12 hours of irradiation, the vial was removed, opened to air, and (1S,2S,3R,5S)-(+)-pinanediol (340 mg, $0.75 \mathrm{mmol}, 4$ equiv.) was added. The resulting suspension was rapidly stirred for 4 hours. The solution was then filtered through a disposable frit and concentrated to remove a majority of the solvent. The residue was purified by flash column chromatography ( (75.2 mg, $0.18 \mathrm{mmol}, 37 \%$ yield title compound).

${ }^{1}$ H NMR (400 MHz, MeOD) $\delta 7.36-7.31(\mathrm{~m}, 2 \mathrm{H}), 7.28(\mathrm{dd}, J=8.2,2.1 \mathrm{~Hz}, 1 \mathrm{H}), 7.16-7.03$ $(\mathrm{m}, 2 \mathrm{H}), 6.82-6.77(\mathrm{~m}, 2 \mathrm{H}), 4.43(\mathrm{~d}, J=9.7 \mathrm{~Hz}, 1 \mathrm{H}), 4.08(\mathrm{t}, J=2.9 \mathrm{~Hz}, 1 \mathrm{H}), 4.07-3.94(\mathrm{~m}$, 4H), $3.86(\mathrm{dd}, J=11.4,1.7 \mathrm{~Hz}, 1 \mathrm{H}), 3.77-3.65$ (m, 2H), 3.57 (dd, $J=9.6,2.9 \mathrm{~Hz}, 1 \mathrm{H}), 3.43$ (dd, $J=9.7,2.8 \mathrm{~Hz}, 1 \mathrm{H}), 1.36(\mathrm{t}, J=7.0 \mathrm{~Hz}, 3 \mathrm{H})$.

${ }^{13}$ C NMR (126 MHz, MeOD) $\delta$ 158.82, 140.67, 139.76, 134.23, 132.96, 131.99, 130.80, 130.02, $128.21,115.38,78.05,77.46,73.87,73.00,69.13,64.40,63.35,39.25,15.20$.

IR (film) $v_{\max } 3372,2903,1612,1510,1477,1239,1177,1091,1034,802$

HRMS (ESI-TOF) $m / z$ calcd. for $\mathrm{C}_{21} \mathrm{H}_{25} \mathrm{ClO}_{6} \mathrm{Na}^{+}\left([\mathrm{M}+\mathrm{Na}]^{+}\right) 431.12319$, found 431.12409 


\section{0) Spectra for isolated products}

\section{( \pm -trans-tetrahydropyran-3,4-diol (SM 6)}

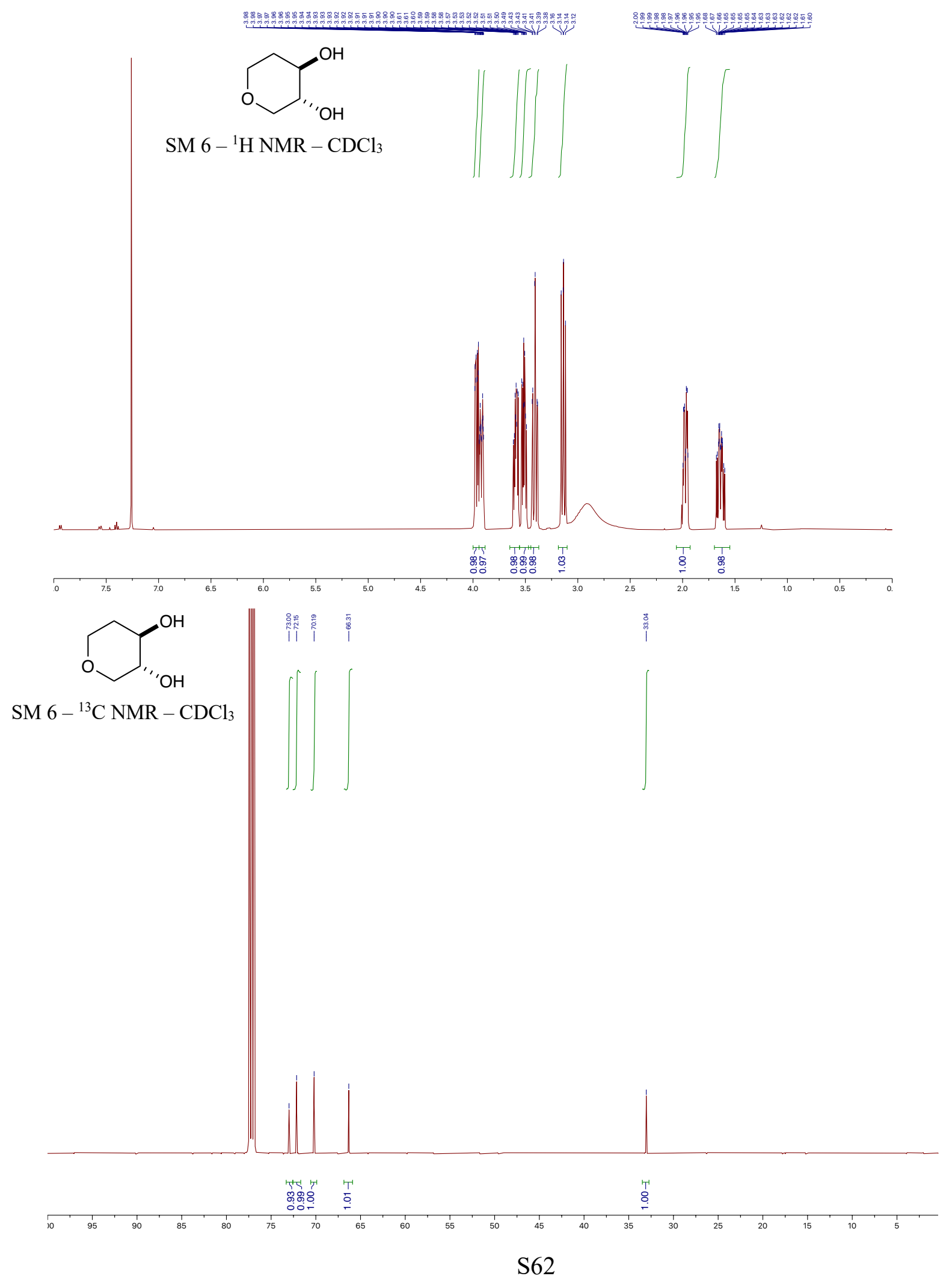




\section{( \pm )-(1RS,2RS,4RS)-menthanetriol (SM 10)}

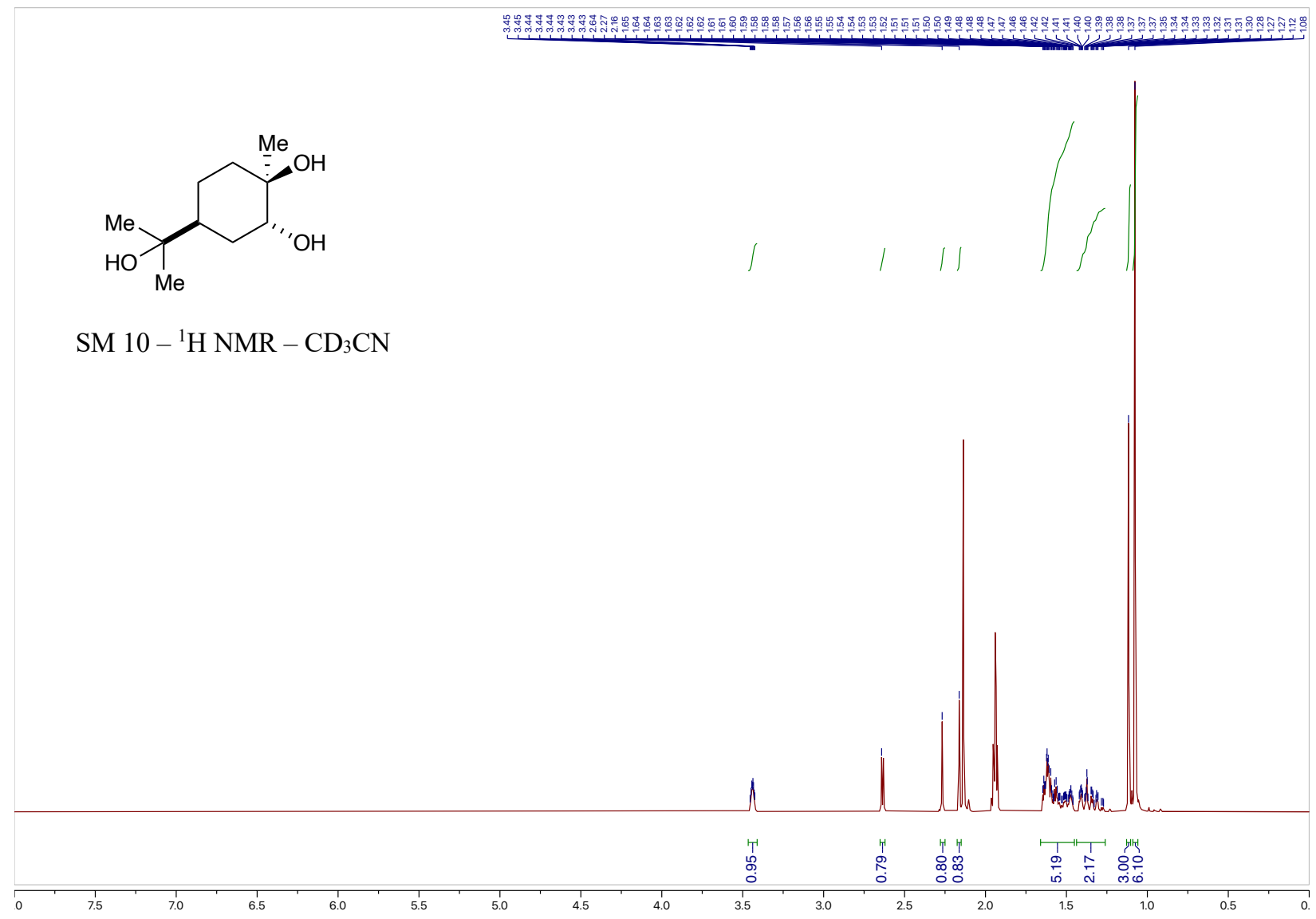


Supporting Information

( \pm -trans-1-methylcyclopentane-1,2-diol (SM 14)

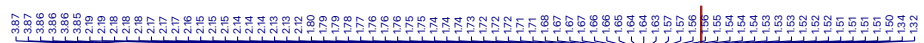

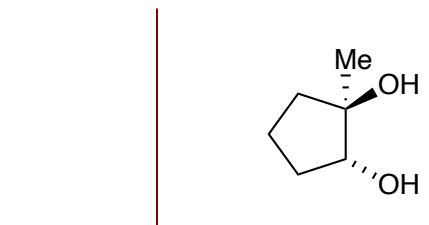

$\mathrm{SM} 14-{ }^{1} \mathrm{H} \mathrm{NMR}-\mathrm{CDCl}_{3}$
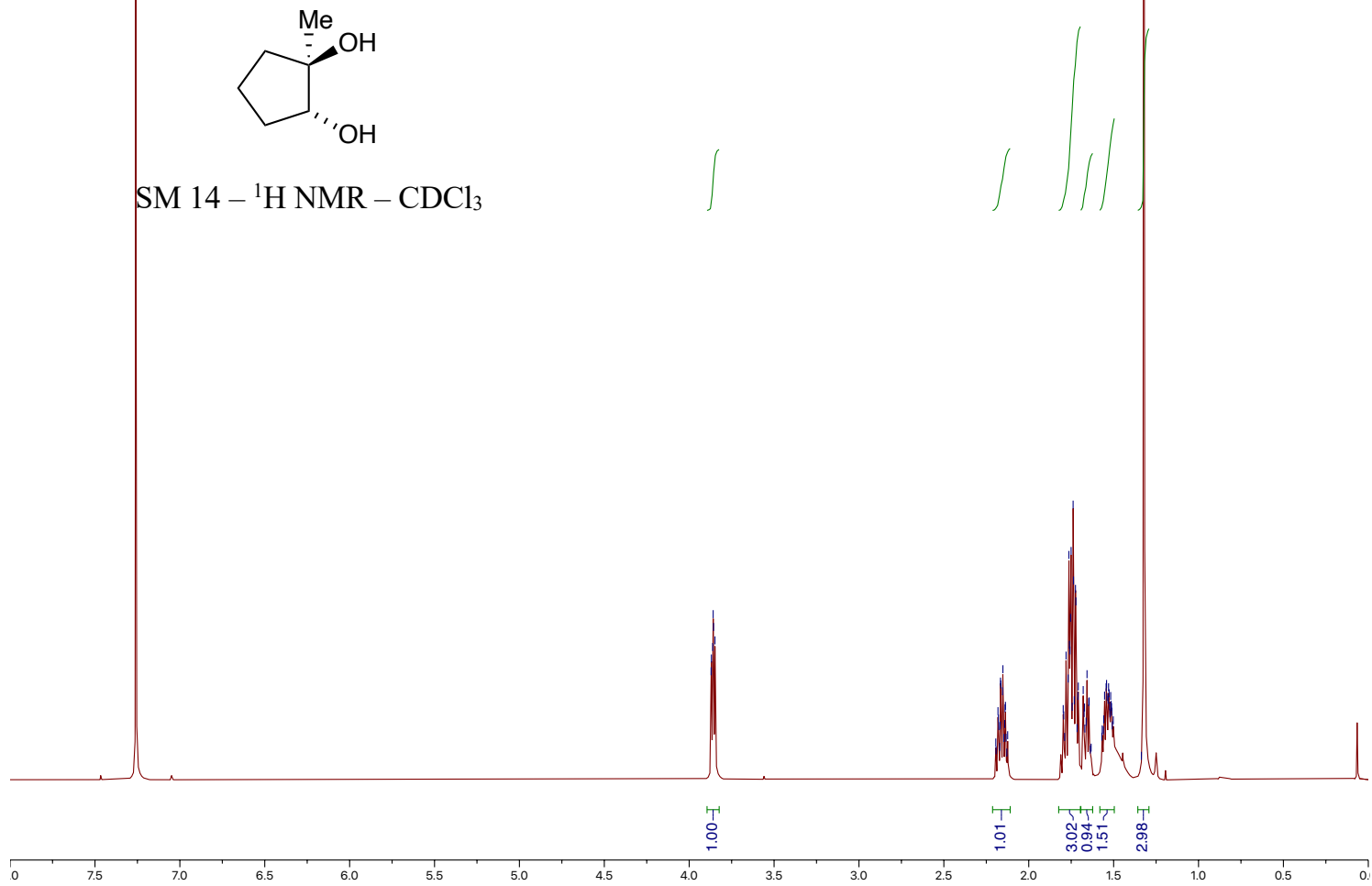

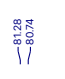
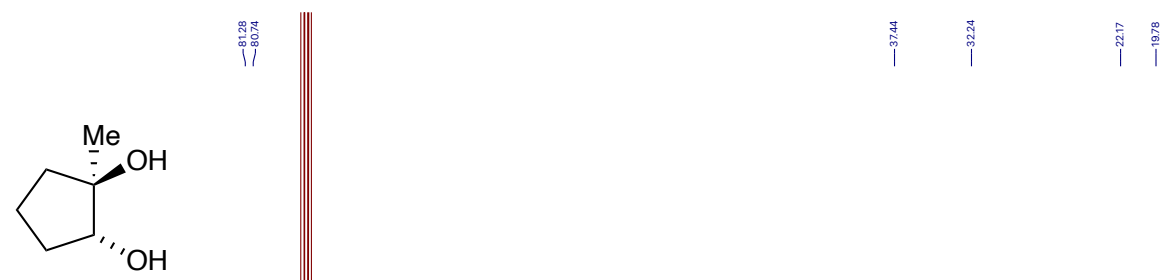

$\mathrm{SM} 14-{ }^{13} \mathrm{C} \mathrm{NMR}-\mathrm{CDCl}_{3}$
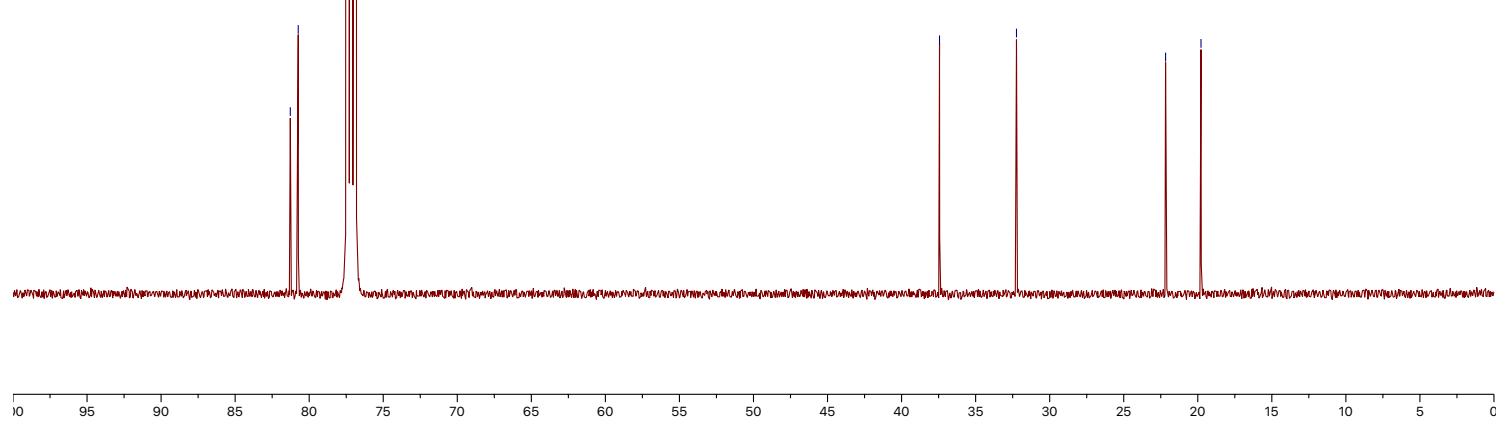


\section{( \pm )-trans-1,2-cyclobutanediol (SM 16)}

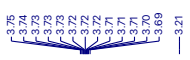

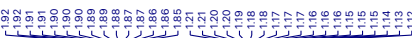<smiles>OC1CC[C@H]1O</smiles>
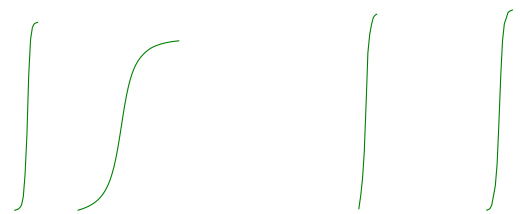

$\mathrm{SM} 16-{ }^{1} \mathrm{H} \mathrm{NMR}-\mathrm{CD}_{3} \mathrm{CN}$
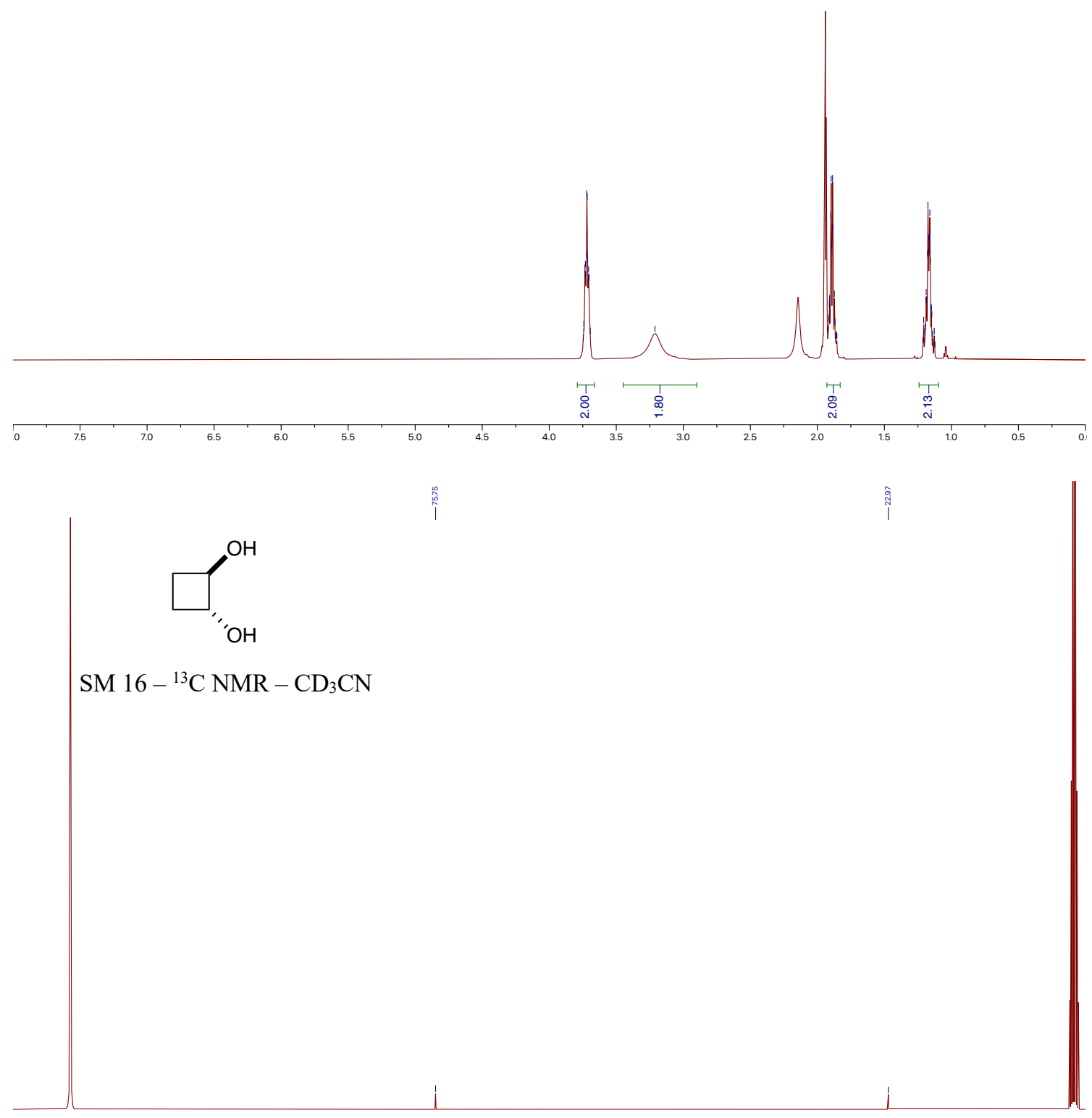


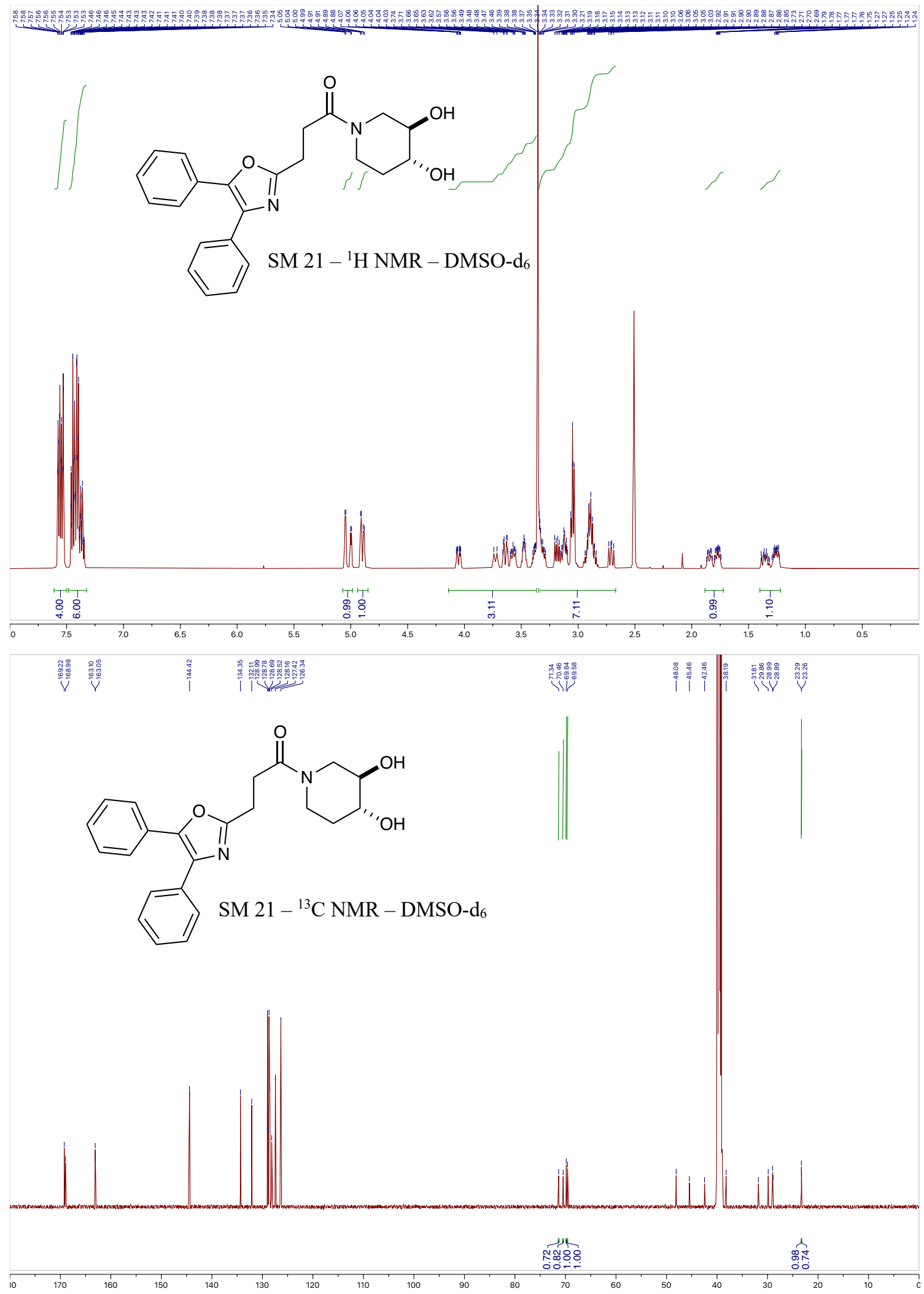


$100{ }^{\circ} \mathbf{C}^{1} \mathbf{H}$ NMR: Peak convergence indicates presence of amide rotamers.

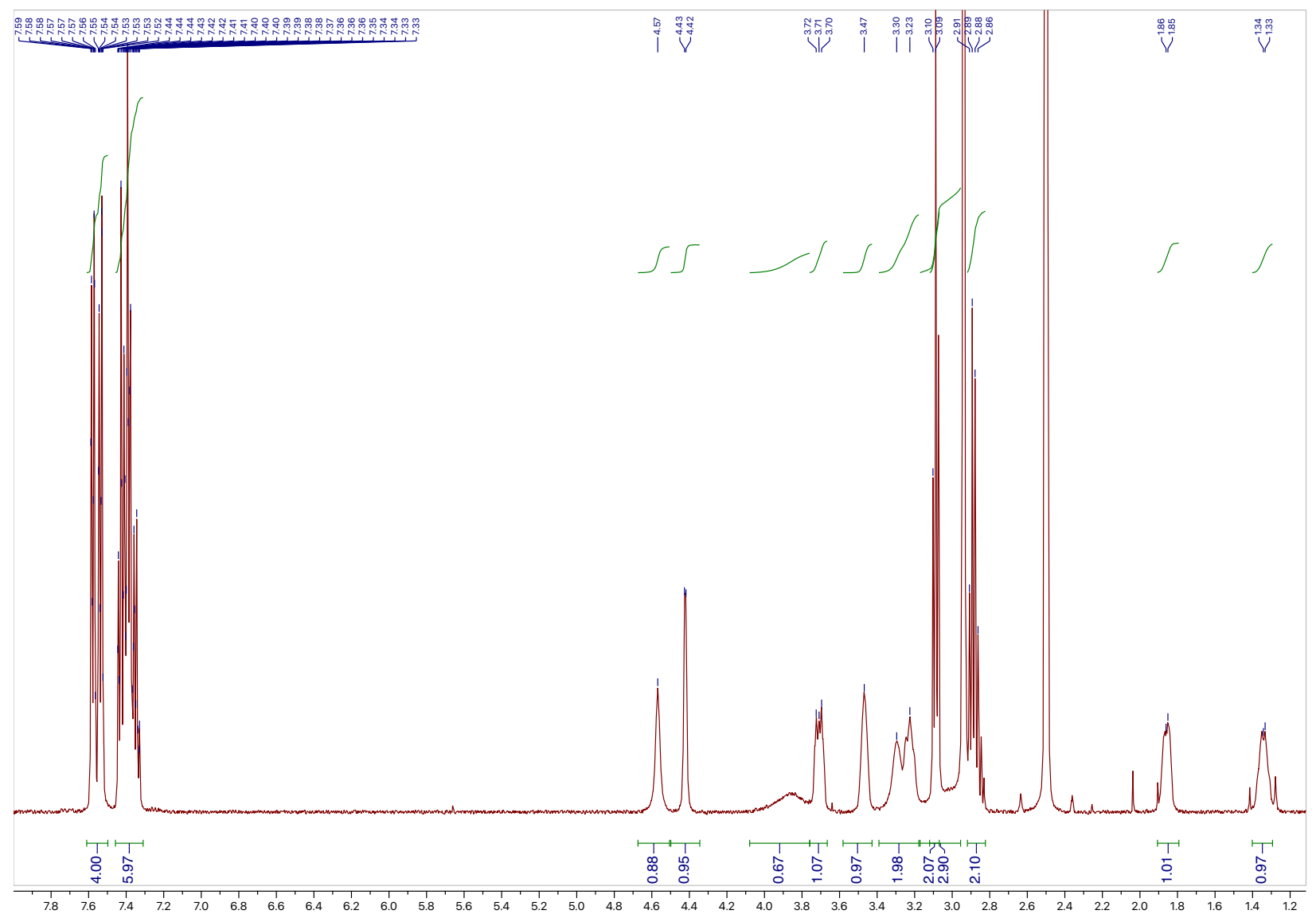


( \pm )-cis-3-hydroxy-4-(hydroxymethyl)tetrahydrofuran (SM 25)
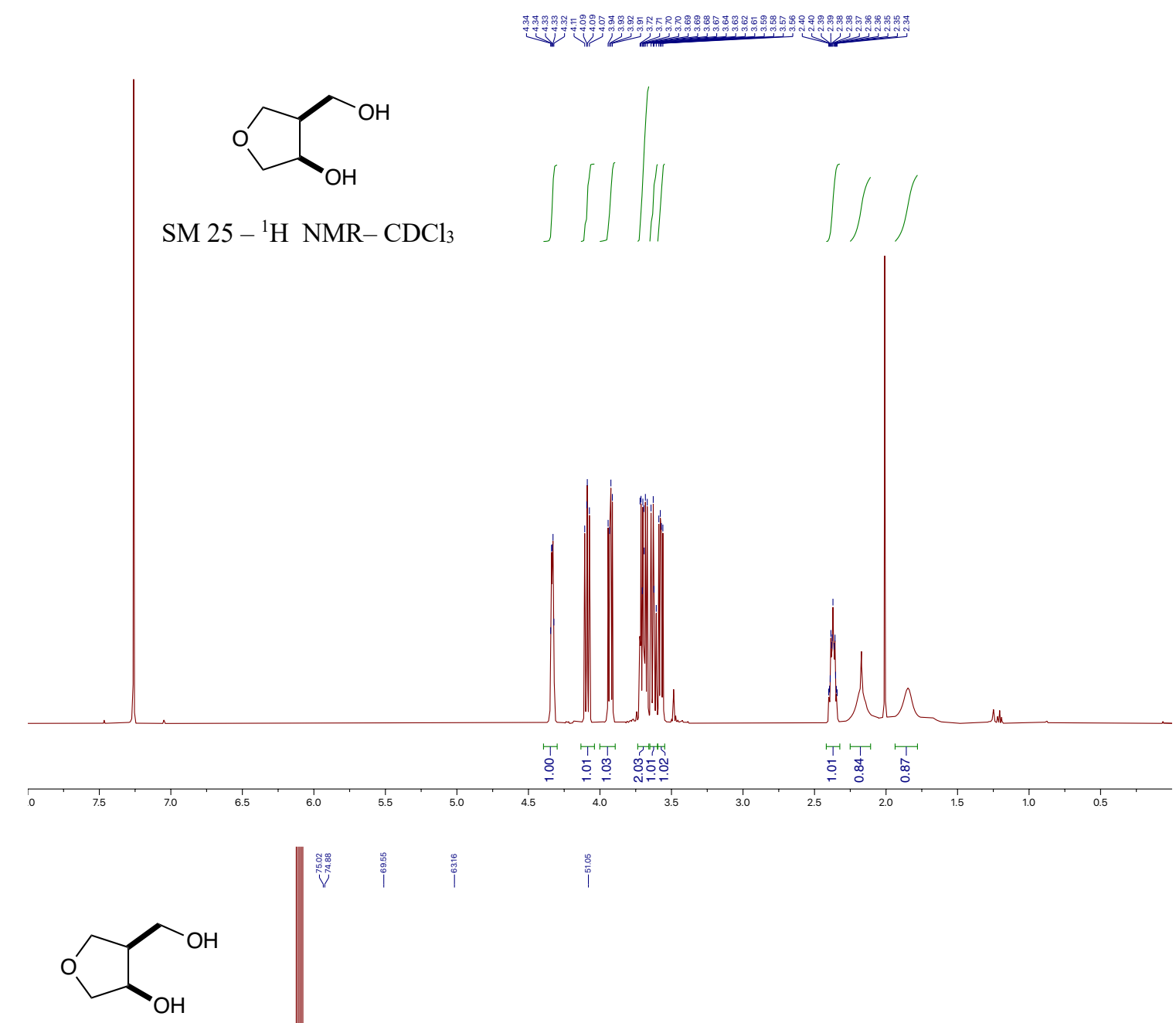

$\mathrm{SM} 25-{ }^{13} \mathrm{C}$ NMR $-\mathrm{CDCl}_{3}$

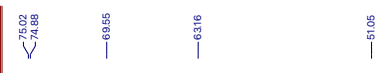

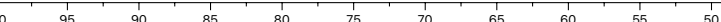


cis-1-2-cyclohexanediol (3)

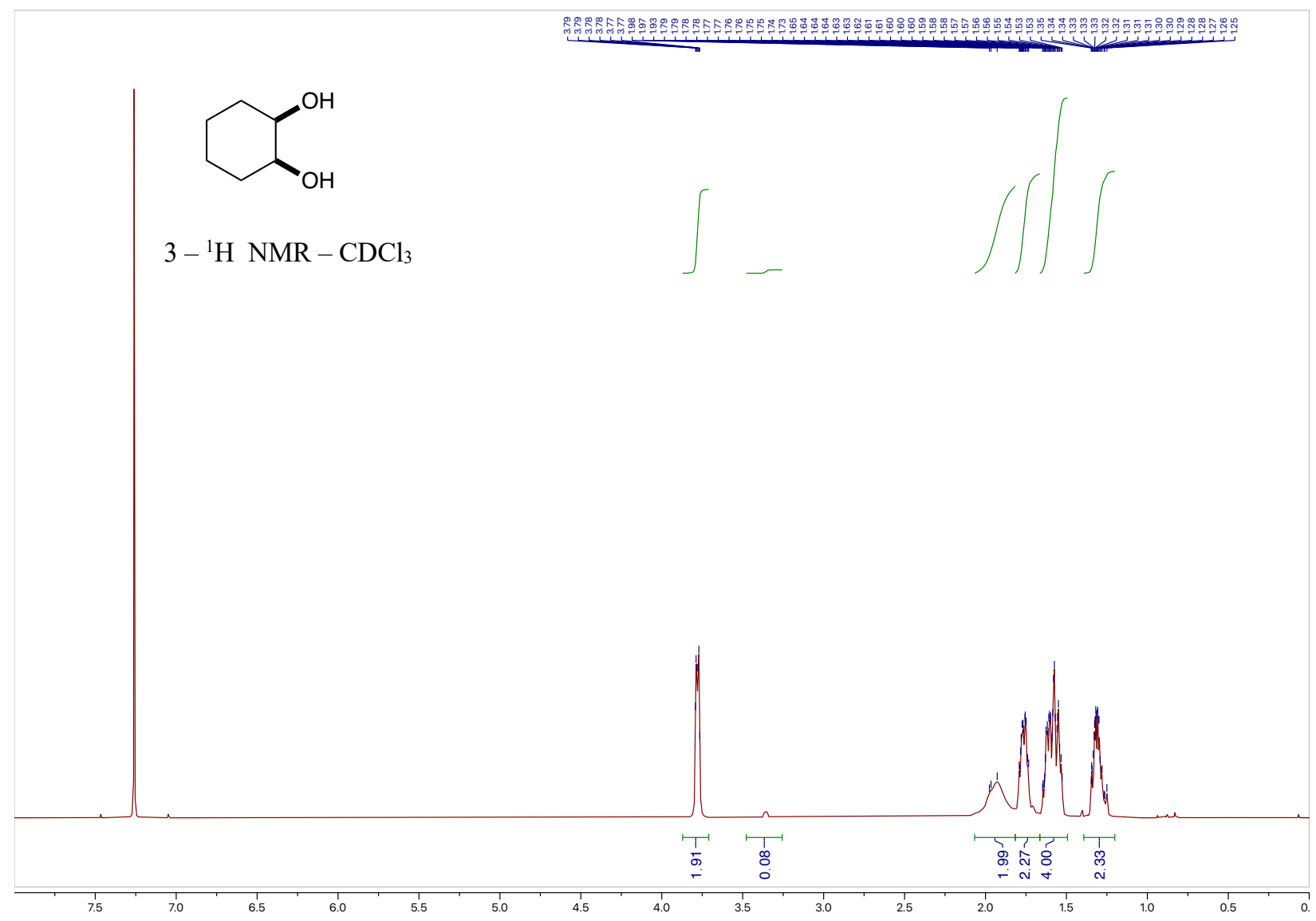


( \pm )-cis-3,4-tetrahydropyrandiol (6)
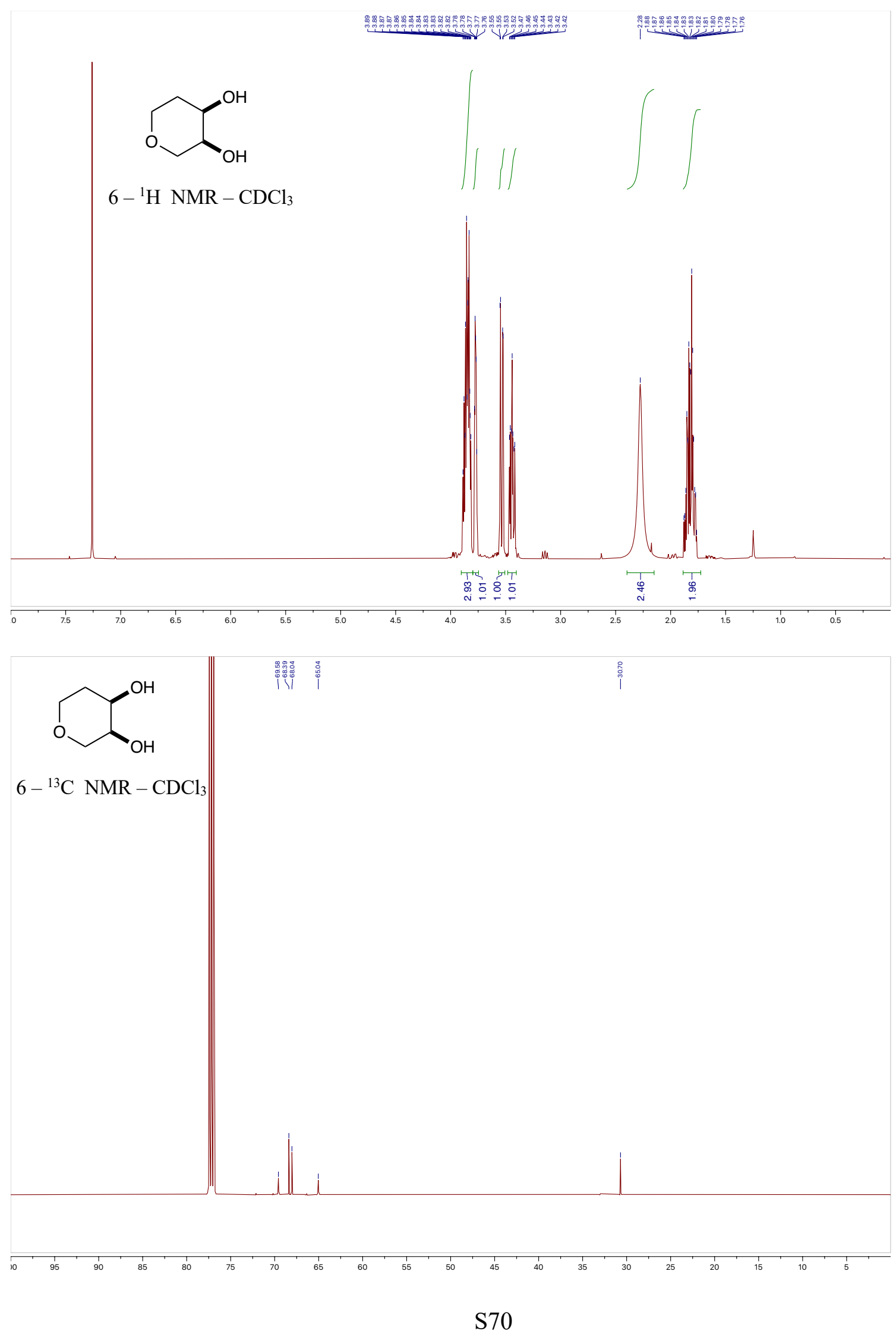


\section{( \pm )-N-Boc-cis-3,4-piperidinediol (7)}

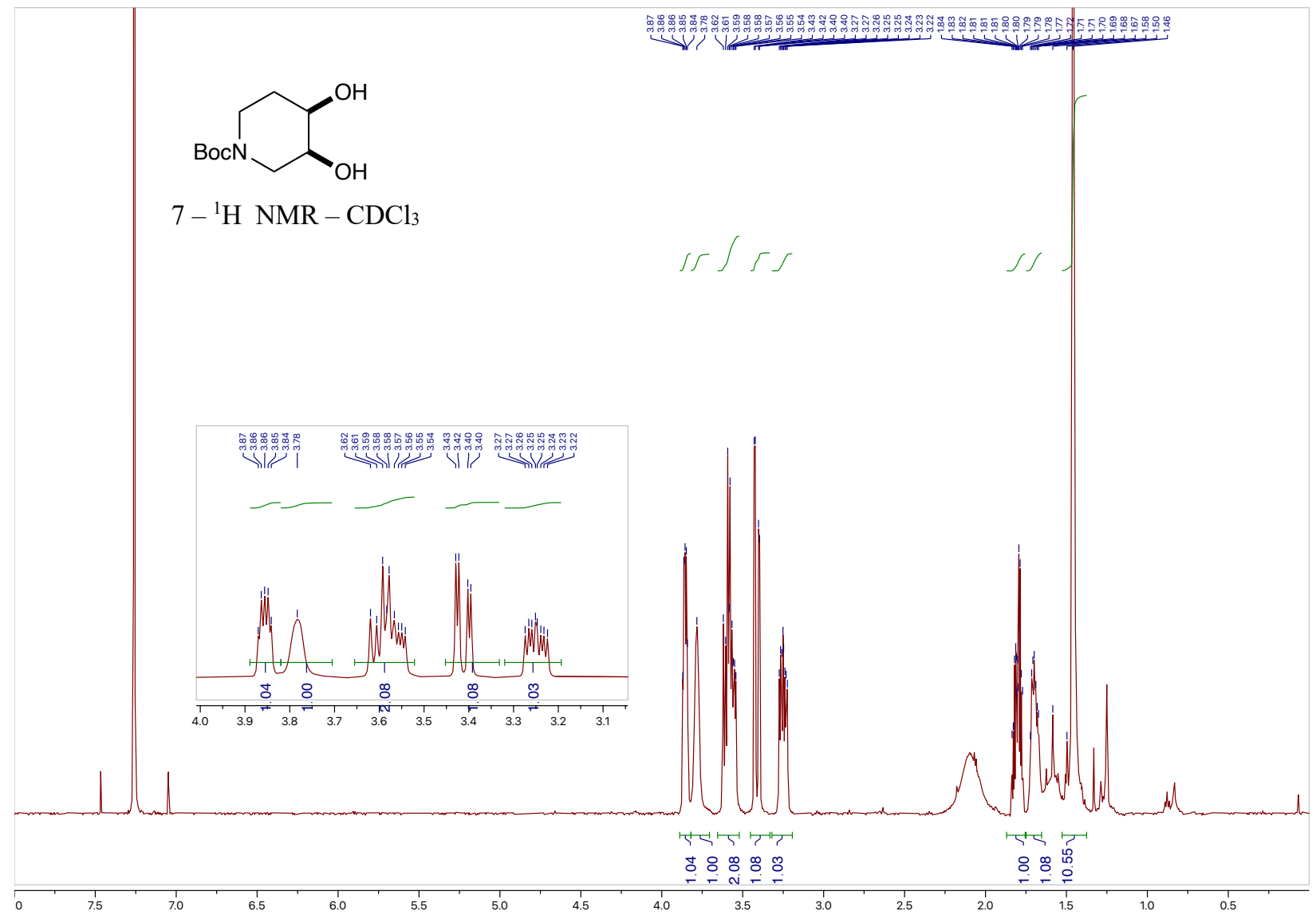


cis-1,2,3,4-tetrahydronaphthalene-2,3-diol (8)

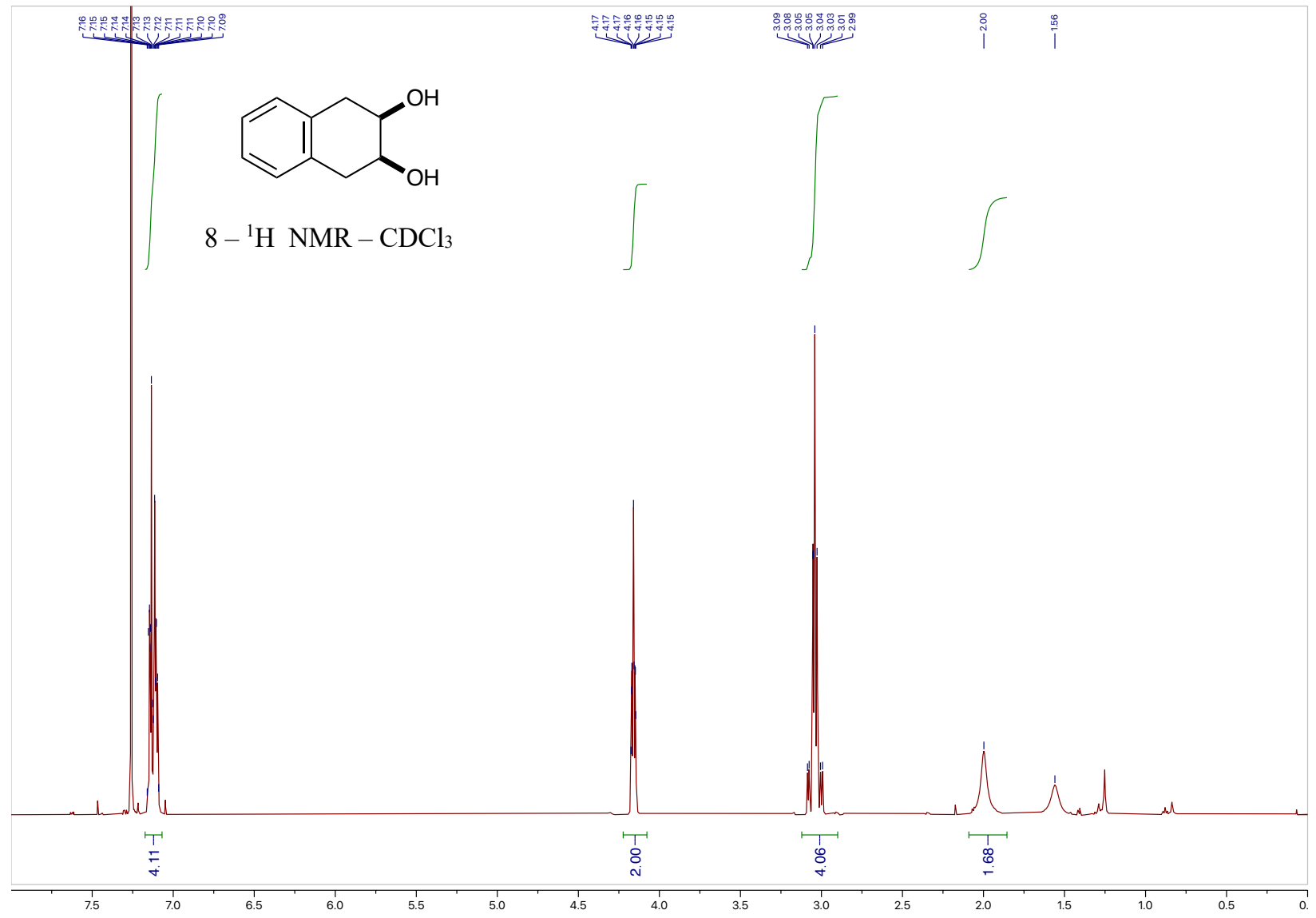




\section{(土)-cis-1-methylcyclohexane-1,2-diol (9)}

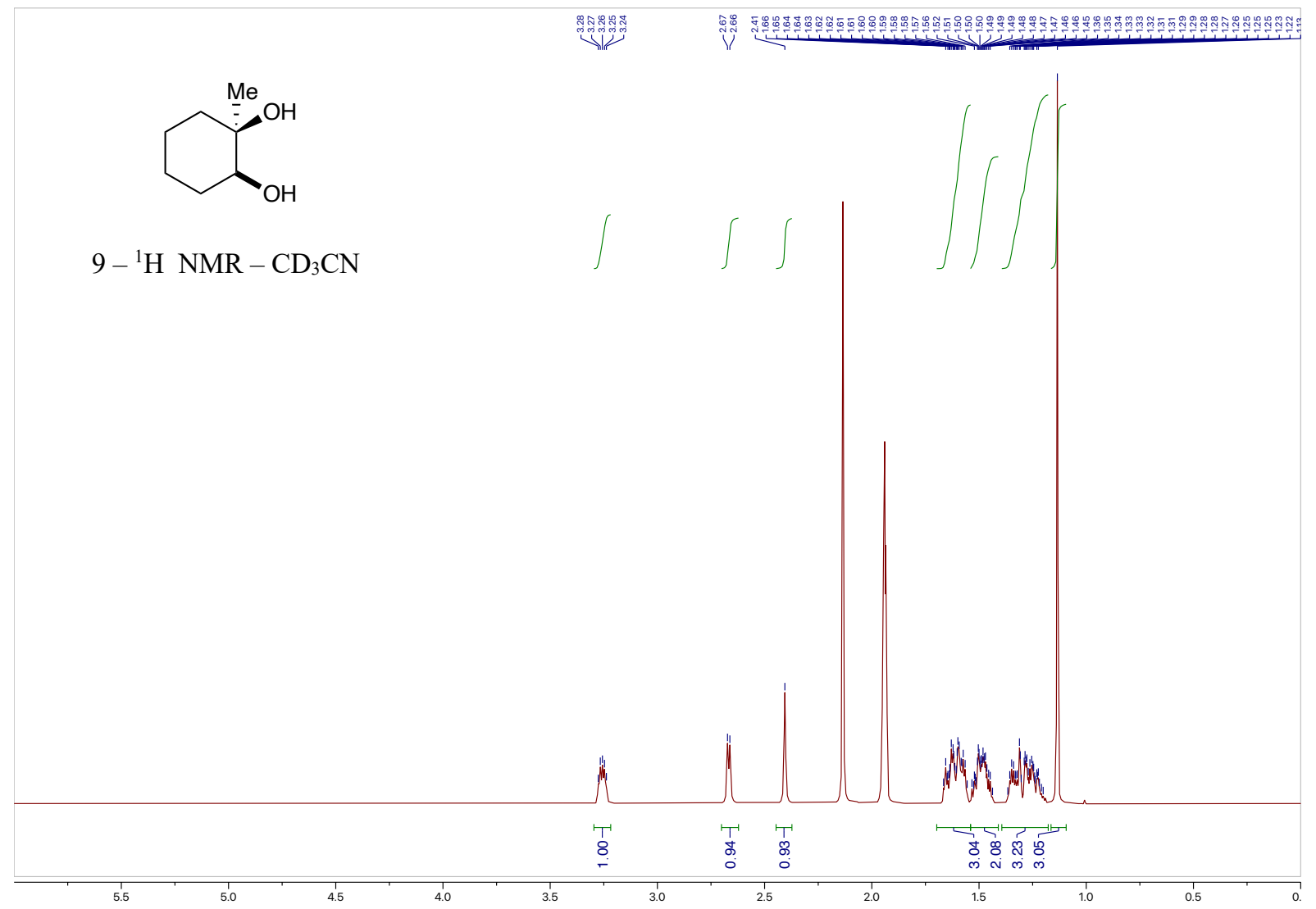




\section{( \pm )-(1RS,2RS,4RS)-menthanetriol (10)}

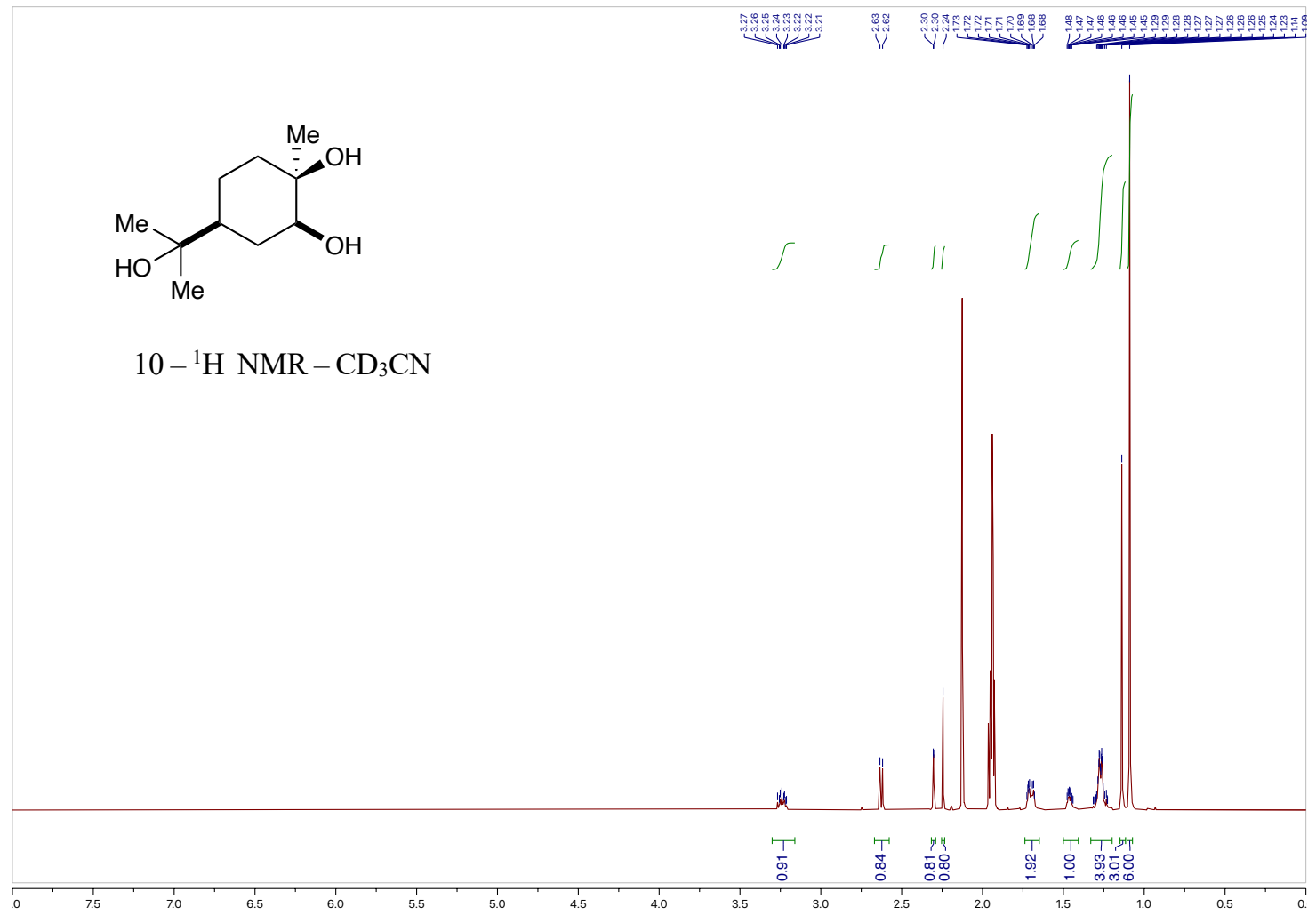

Analytical yield ${ }^{1} \mathrm{H}$ NMR ( $\left.\mathrm{CDCl}_{3}\right)$

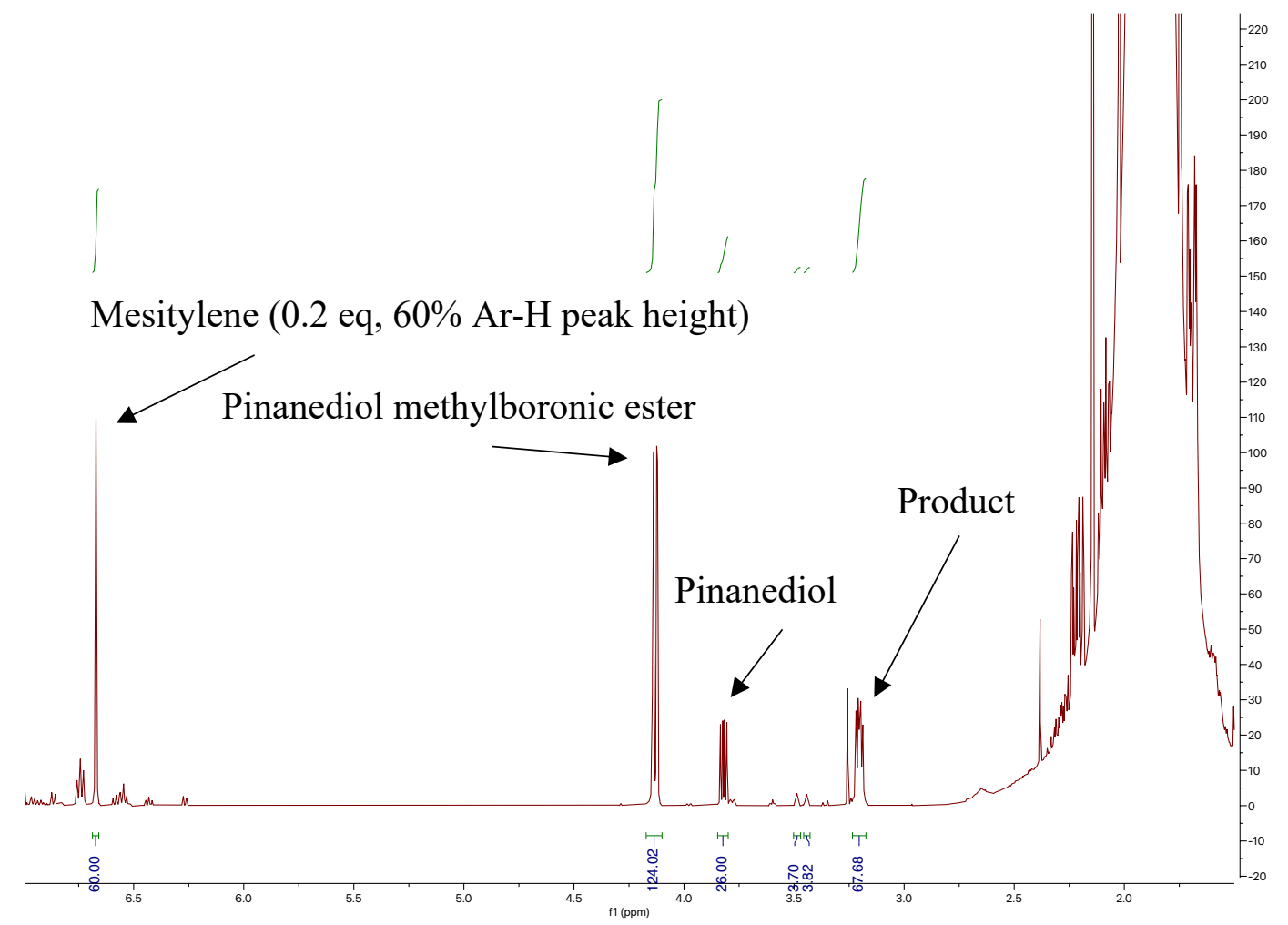


cis-1,2-cyclopentanediol (11)

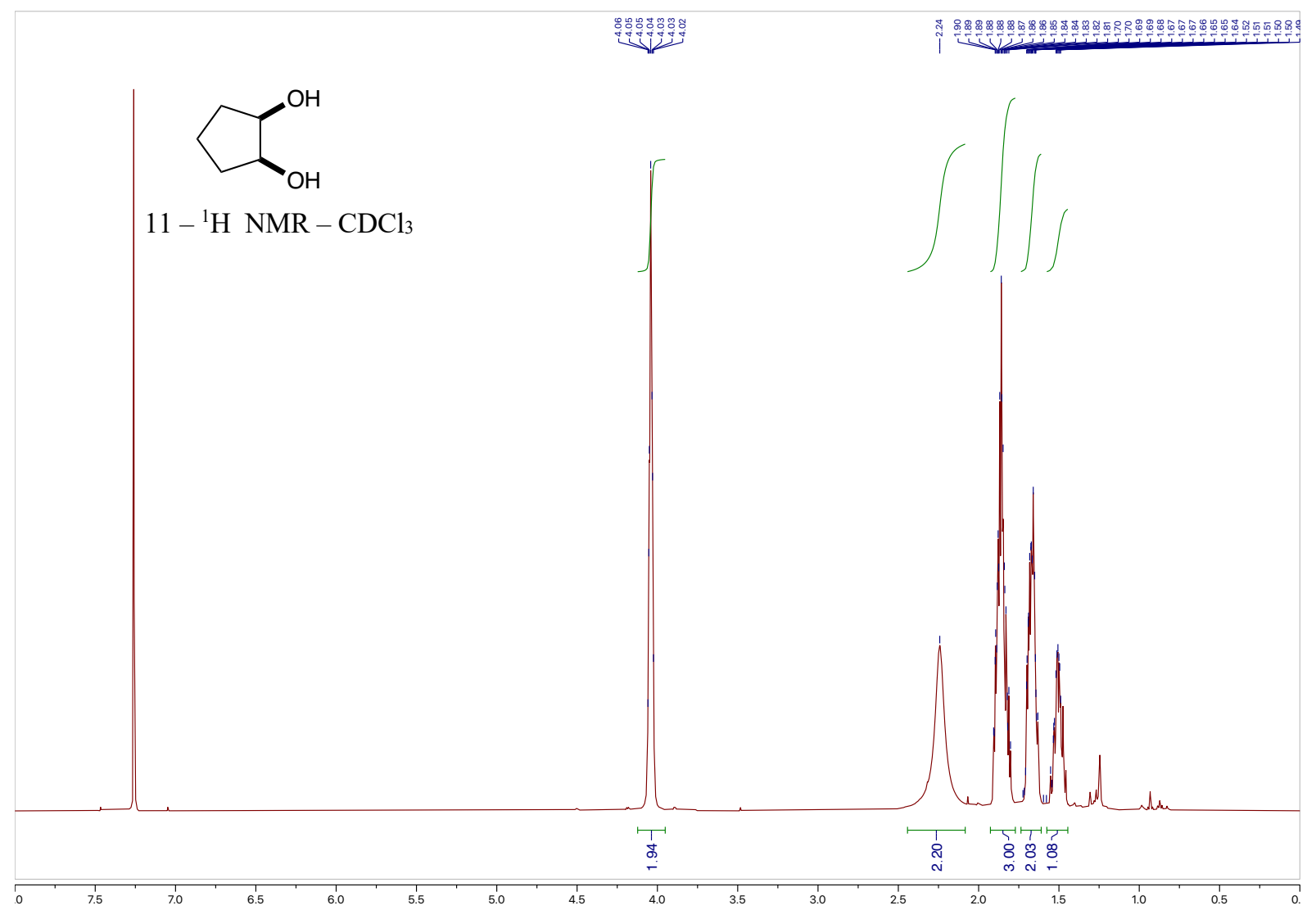


Supporting Information

1,4-anhydroerythritol (12)

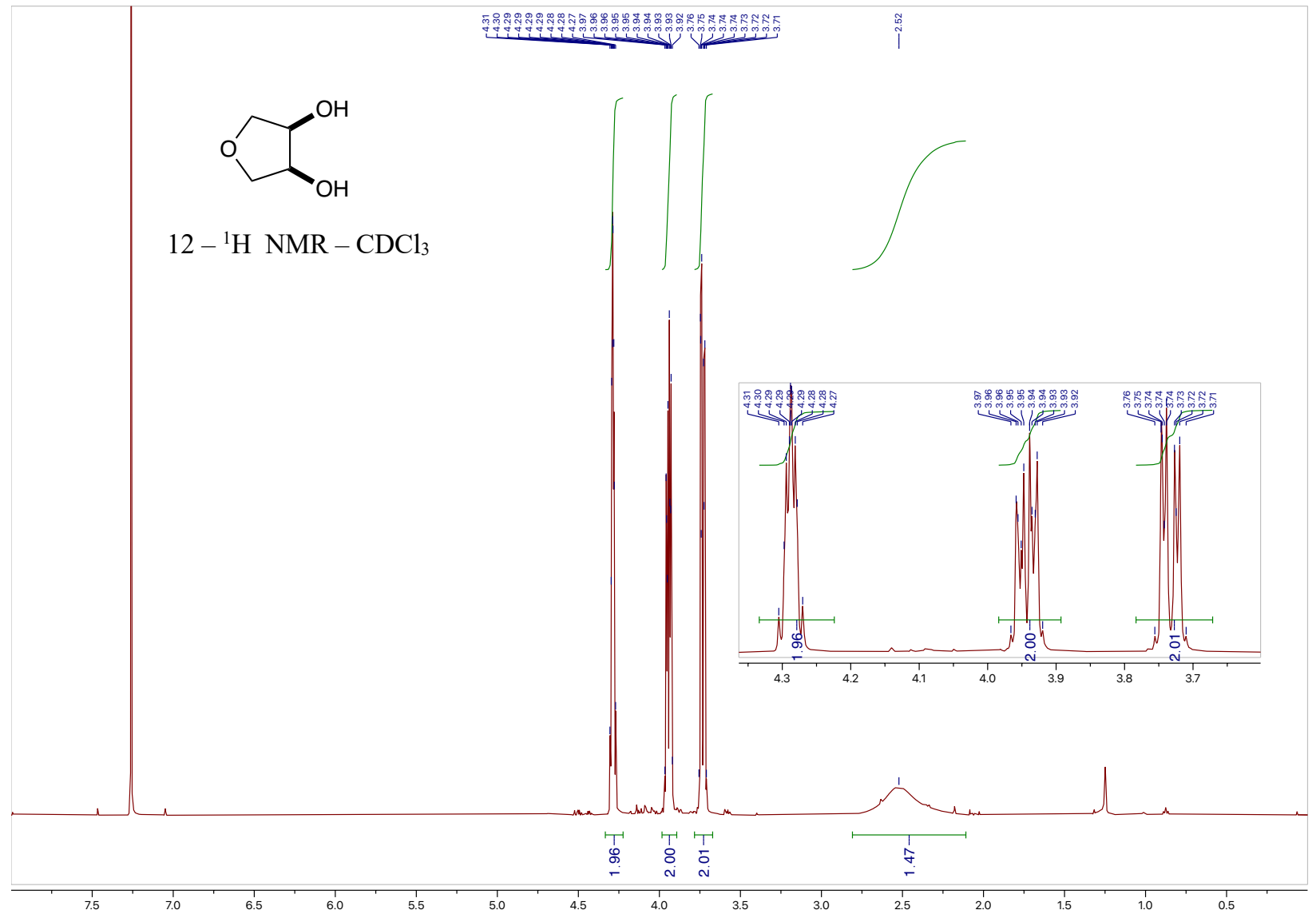




\section{$N$-Boc-cis-3,4-pyrrolidinediol (13)}

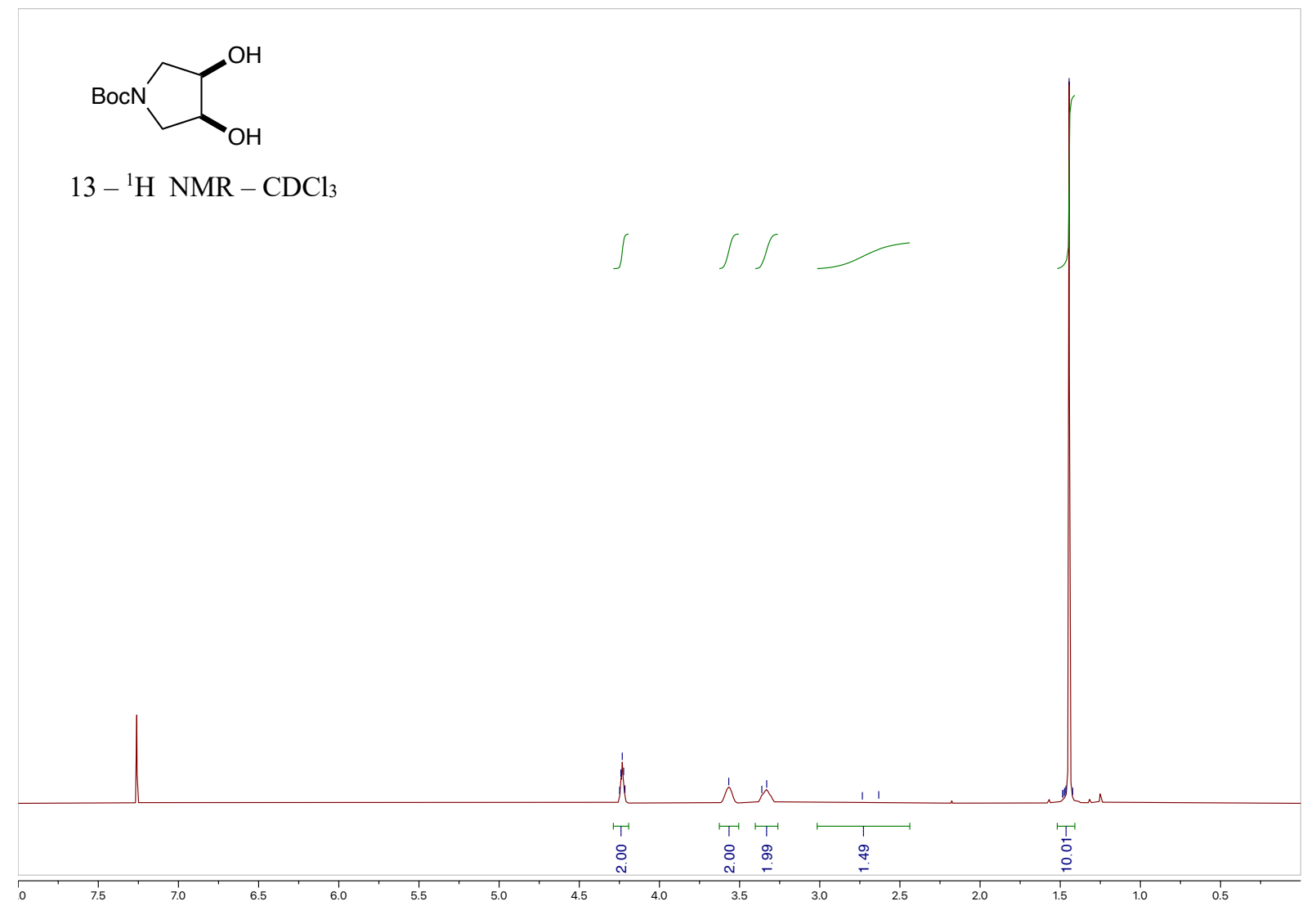


( \pm )-cis-1-methylcyclopentane-1,2-diol (14)

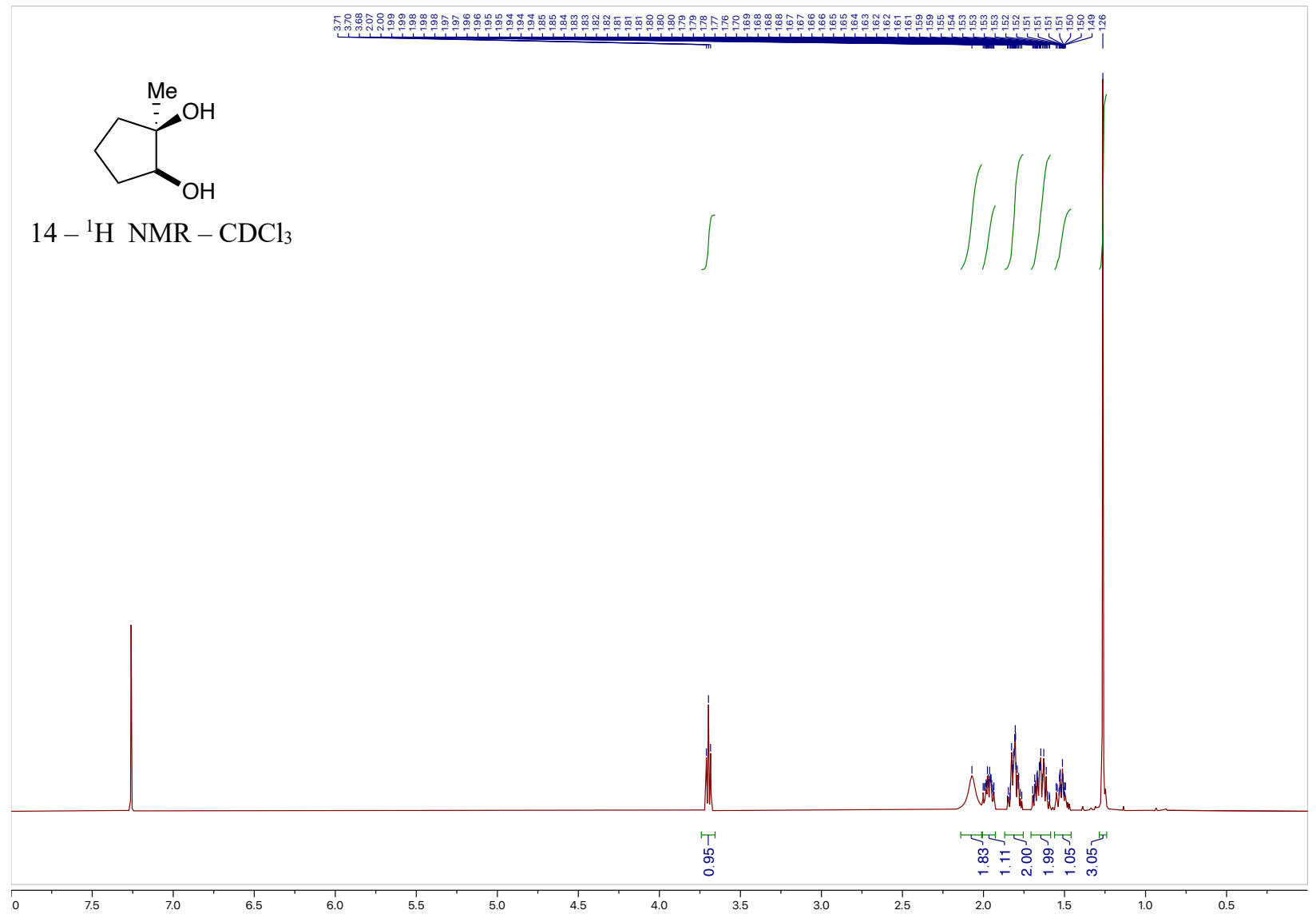




\section{cis-1,2-cycloheptanediol (15)}

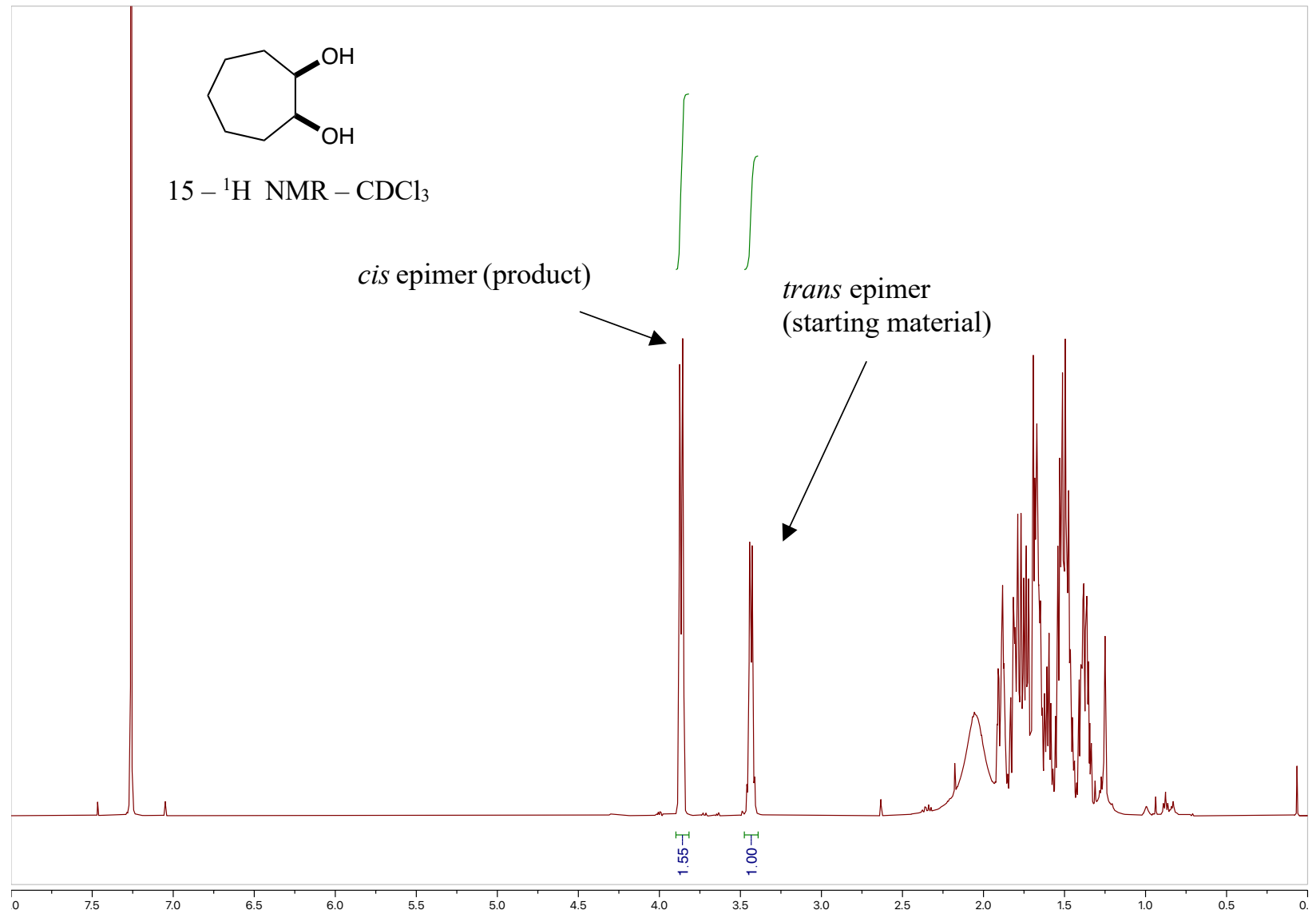


Supporting Information

cis-1,2-cyclobutanediol (16)
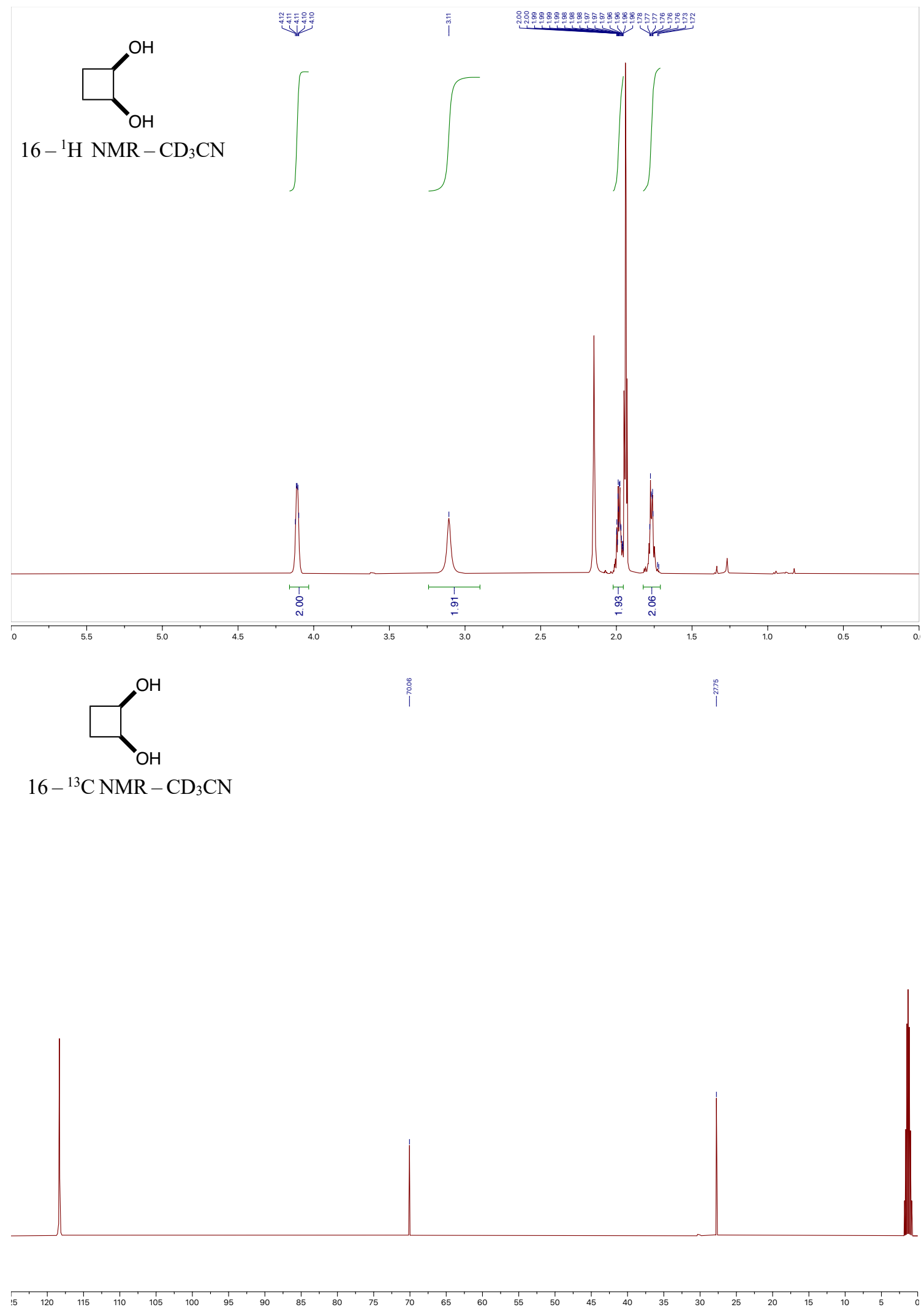
Supporting Information

anti-3.4-hexanediol (17)

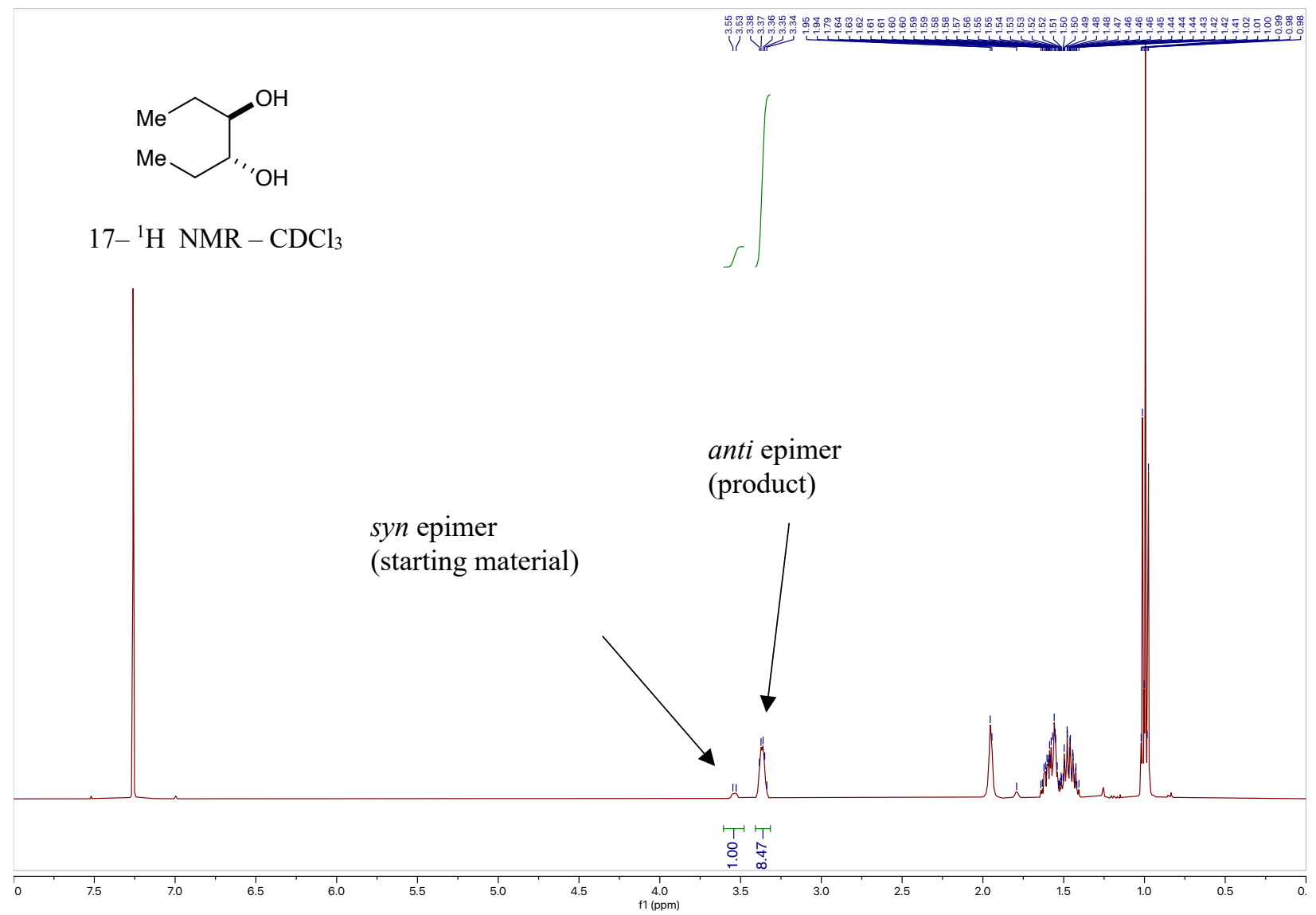


anti-2,3-butanediol (18)
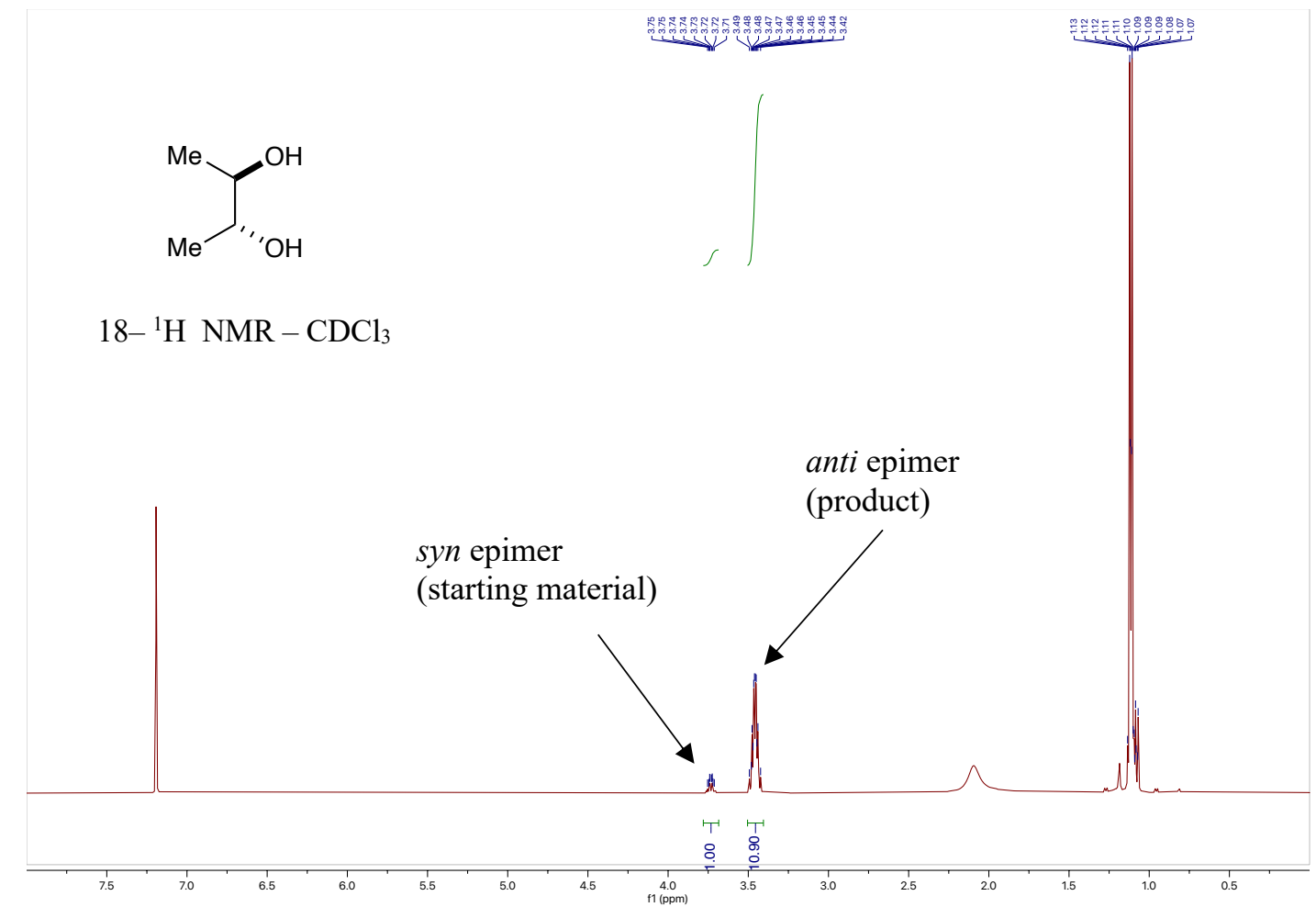

\section{Analytical yield ${ }^{1} \mathrm{H}$ NMR (4:1 $\left.\mathrm{CDCl}_{3} / \mathrm{CH}_{3} \mathrm{CN}\right)$}

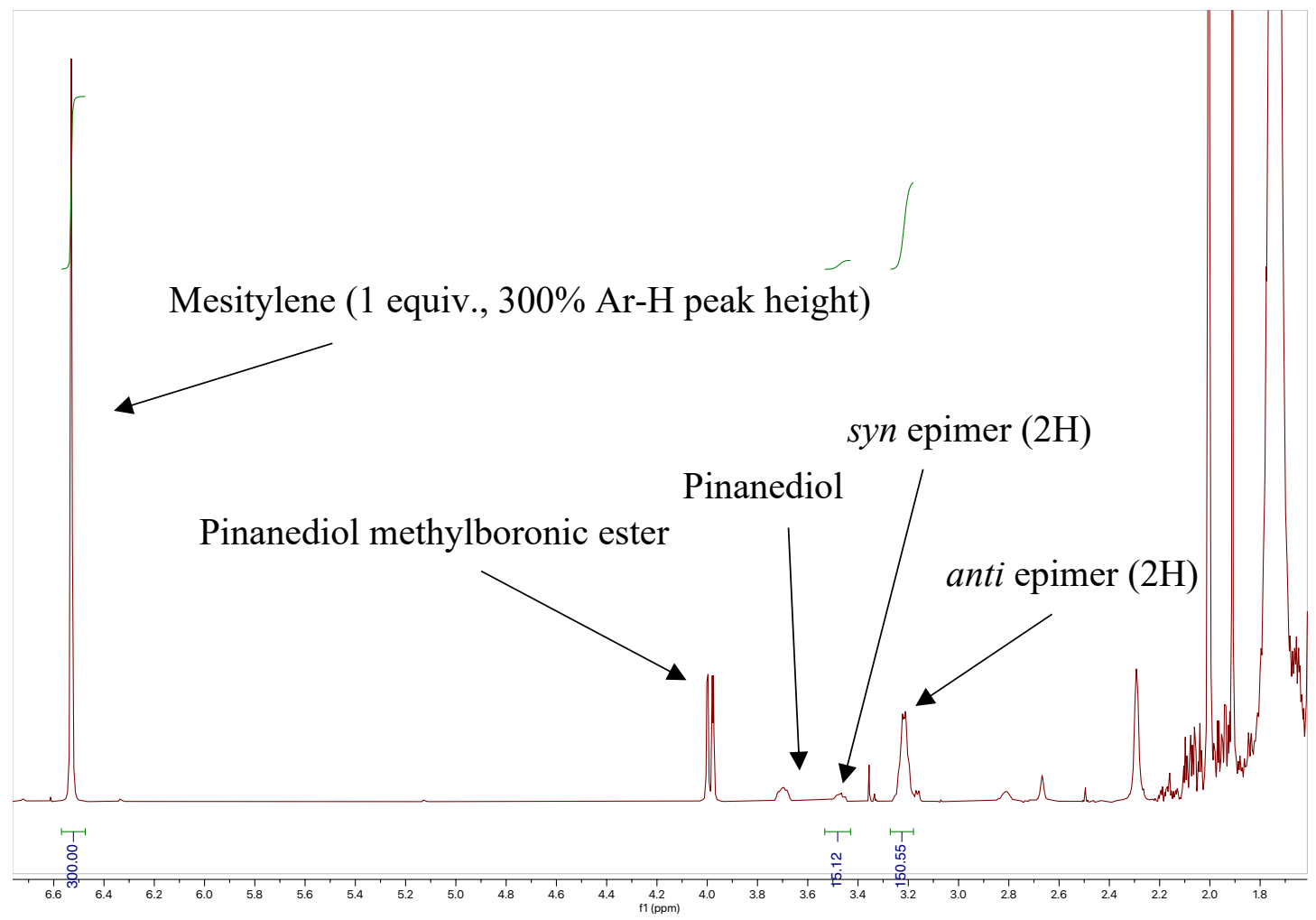


( \pm -anti-4-methyl-2,3-pentanediol (19)

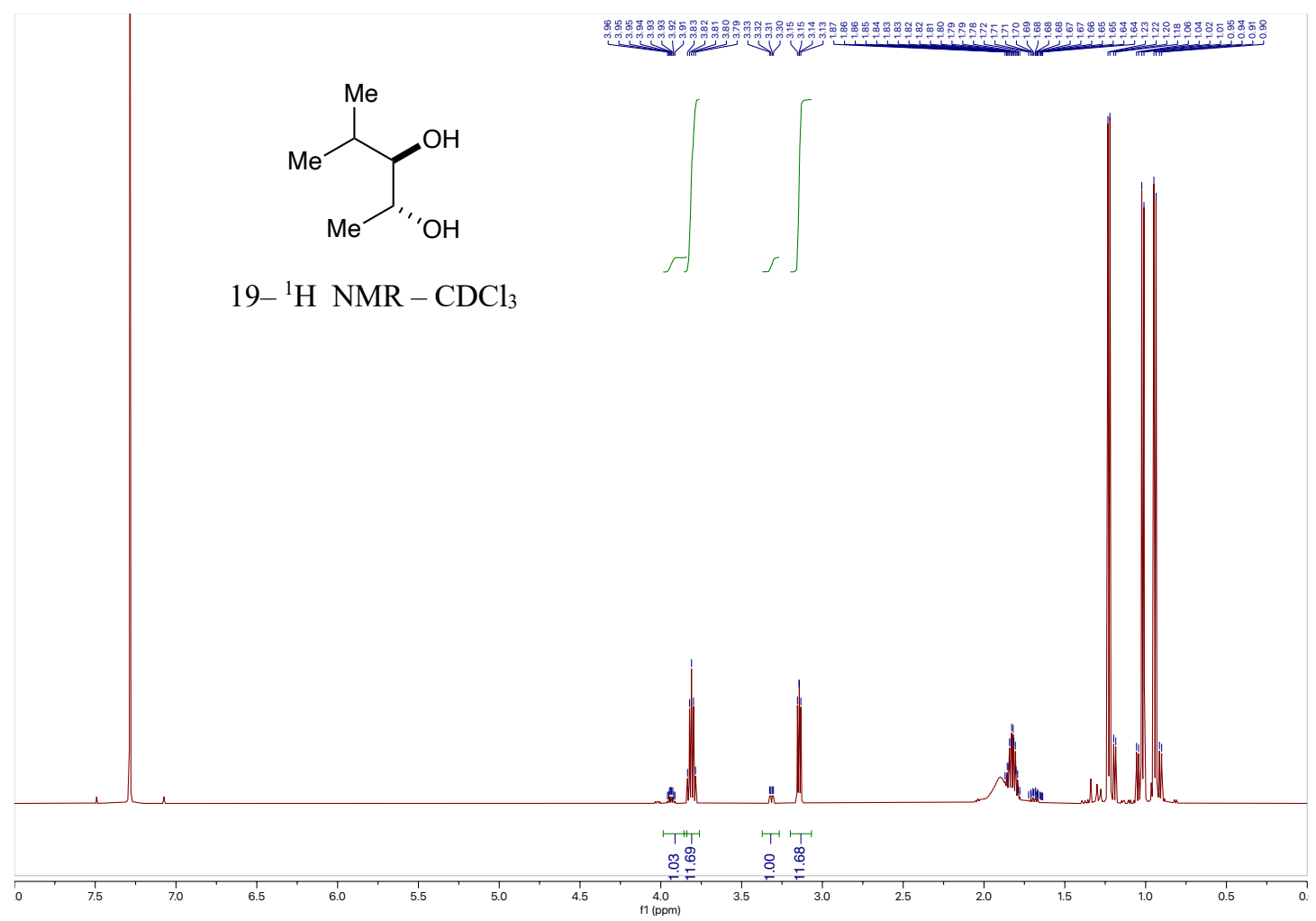

Analytical yield ${ }^{1} \mathrm{H}$ NMR (4:1 $\left.\mathrm{CDCl}_{3} / \mathrm{CH} 3 \mathrm{CN}\right)$

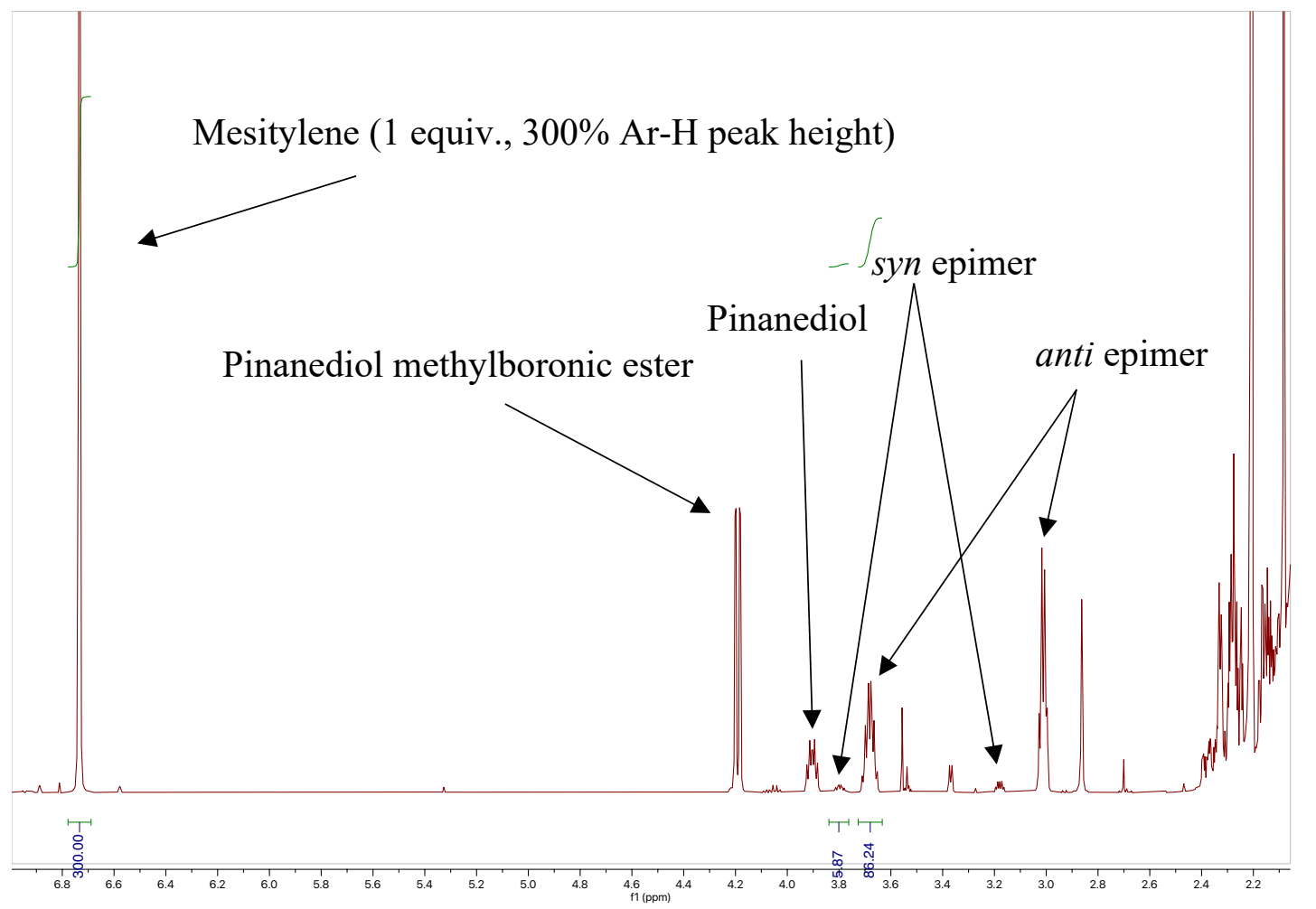


Supporting Information

\section{6ß-epiestriol (20)}
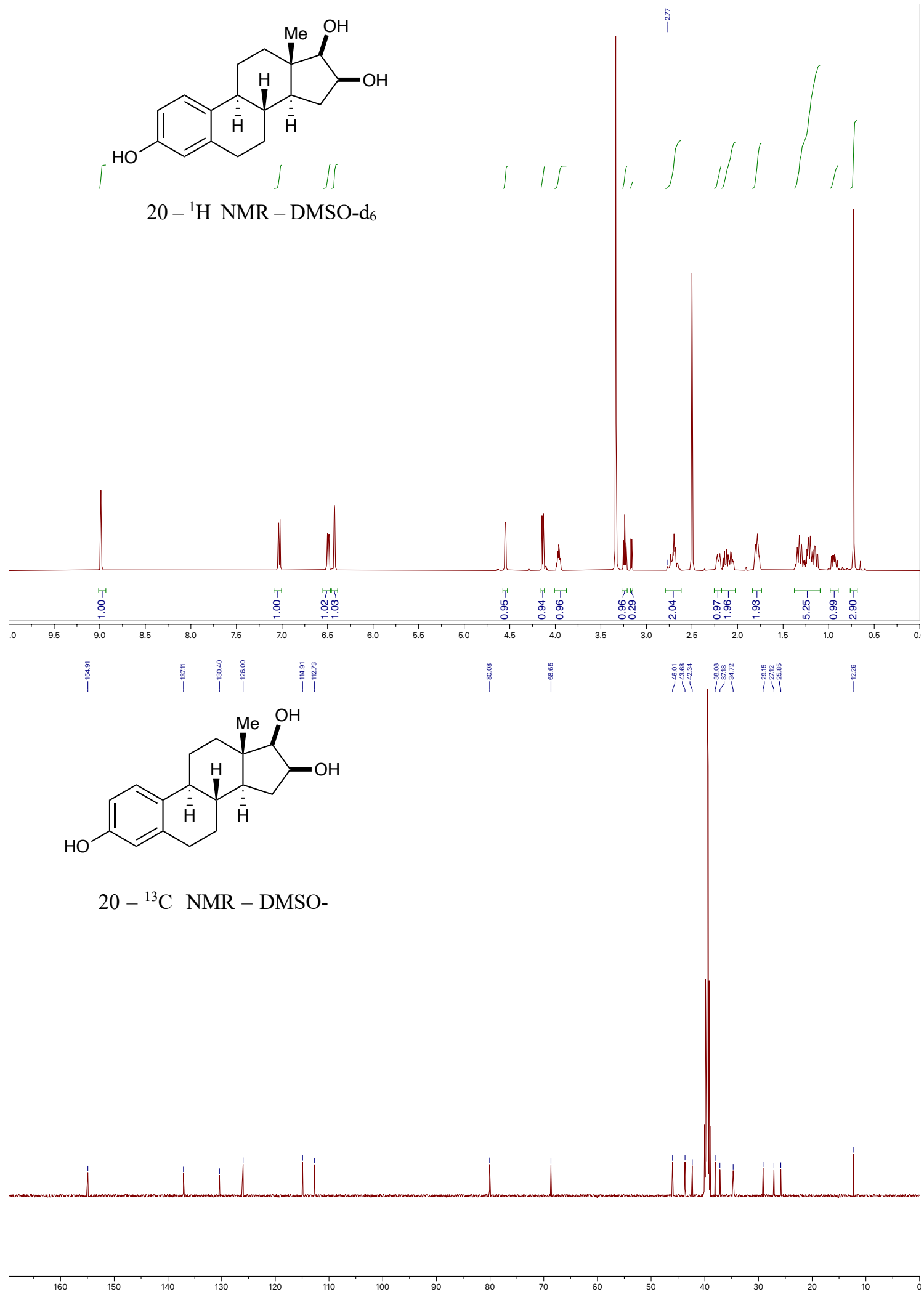
Supporting Information

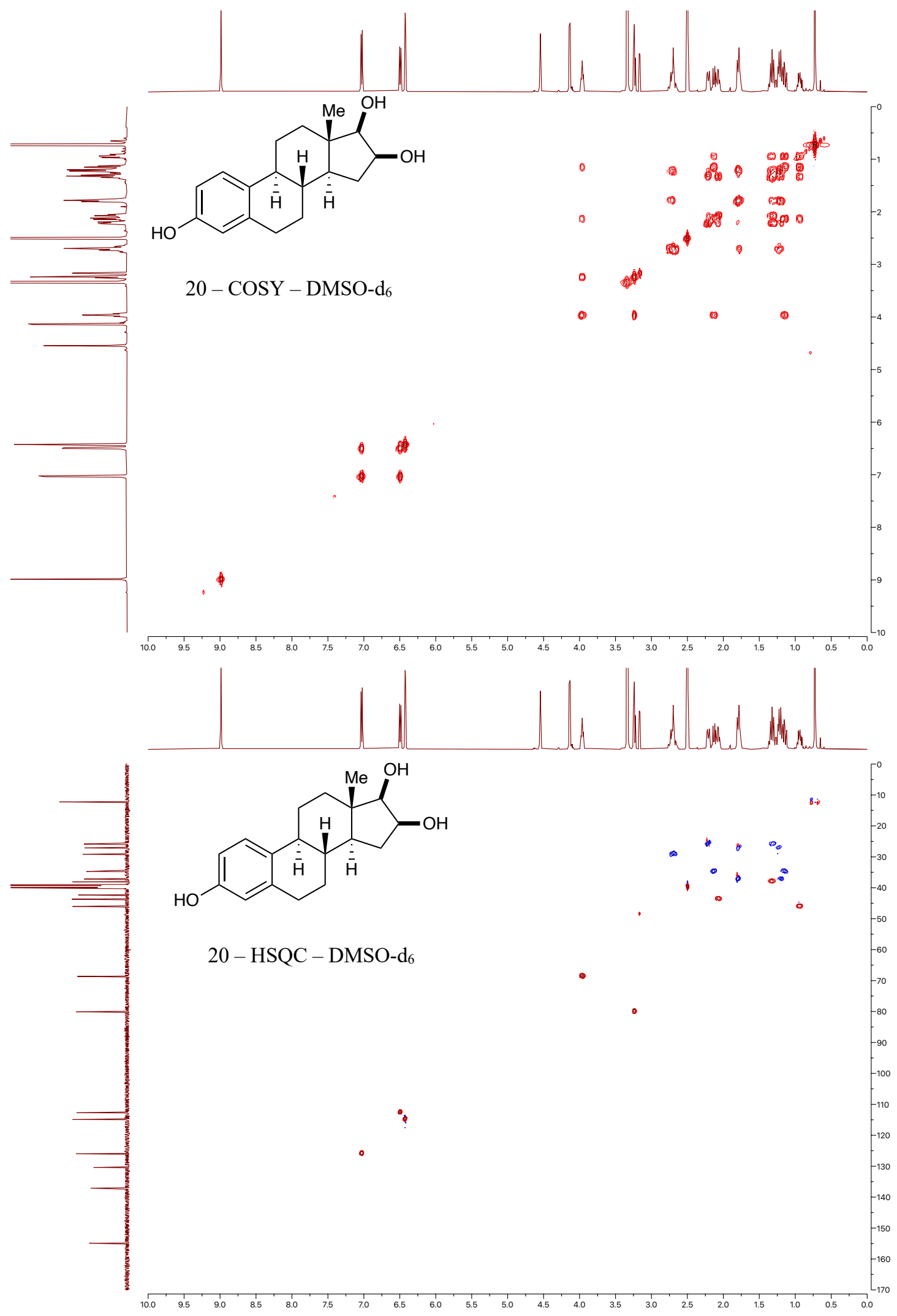


Supporting Information

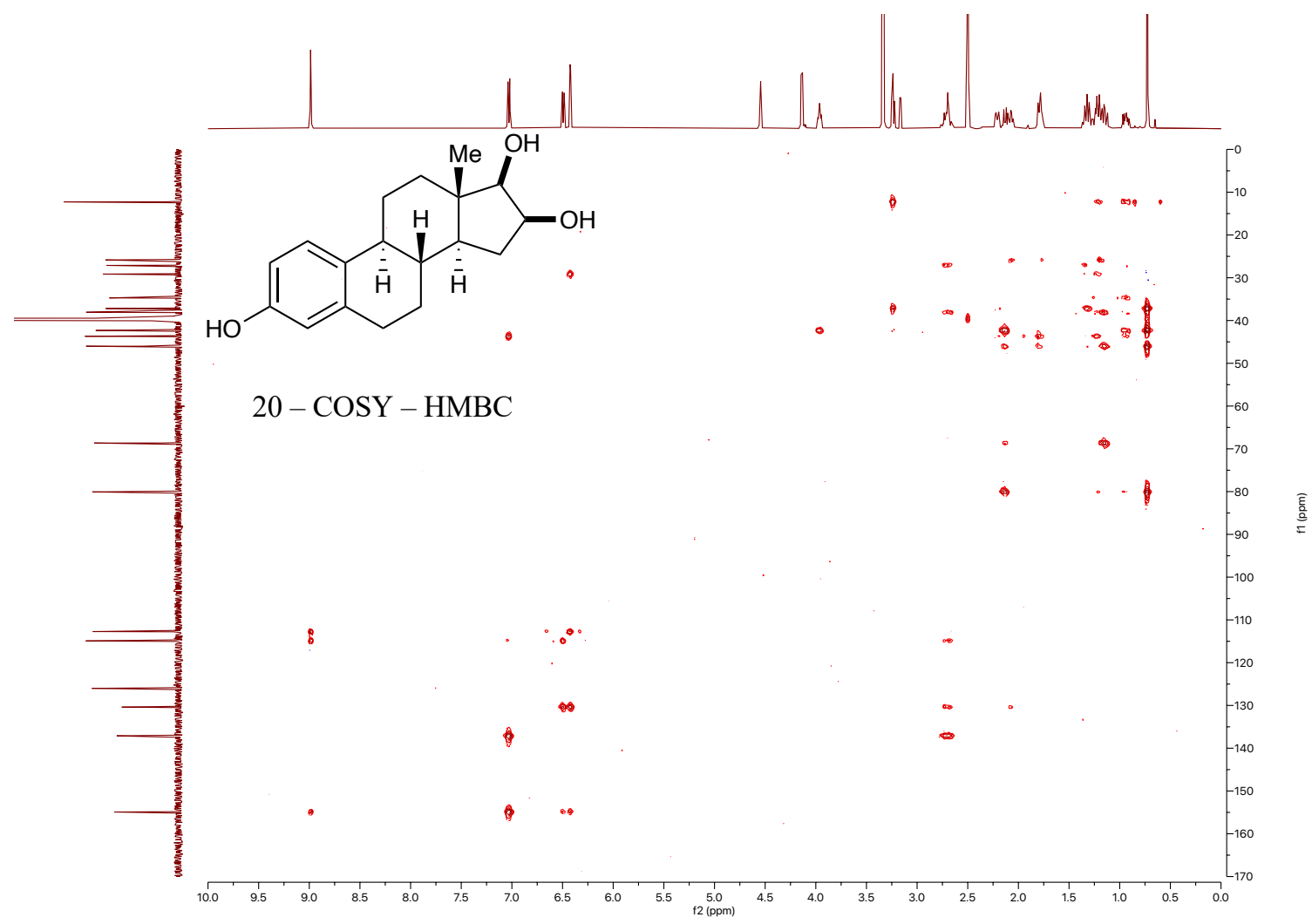



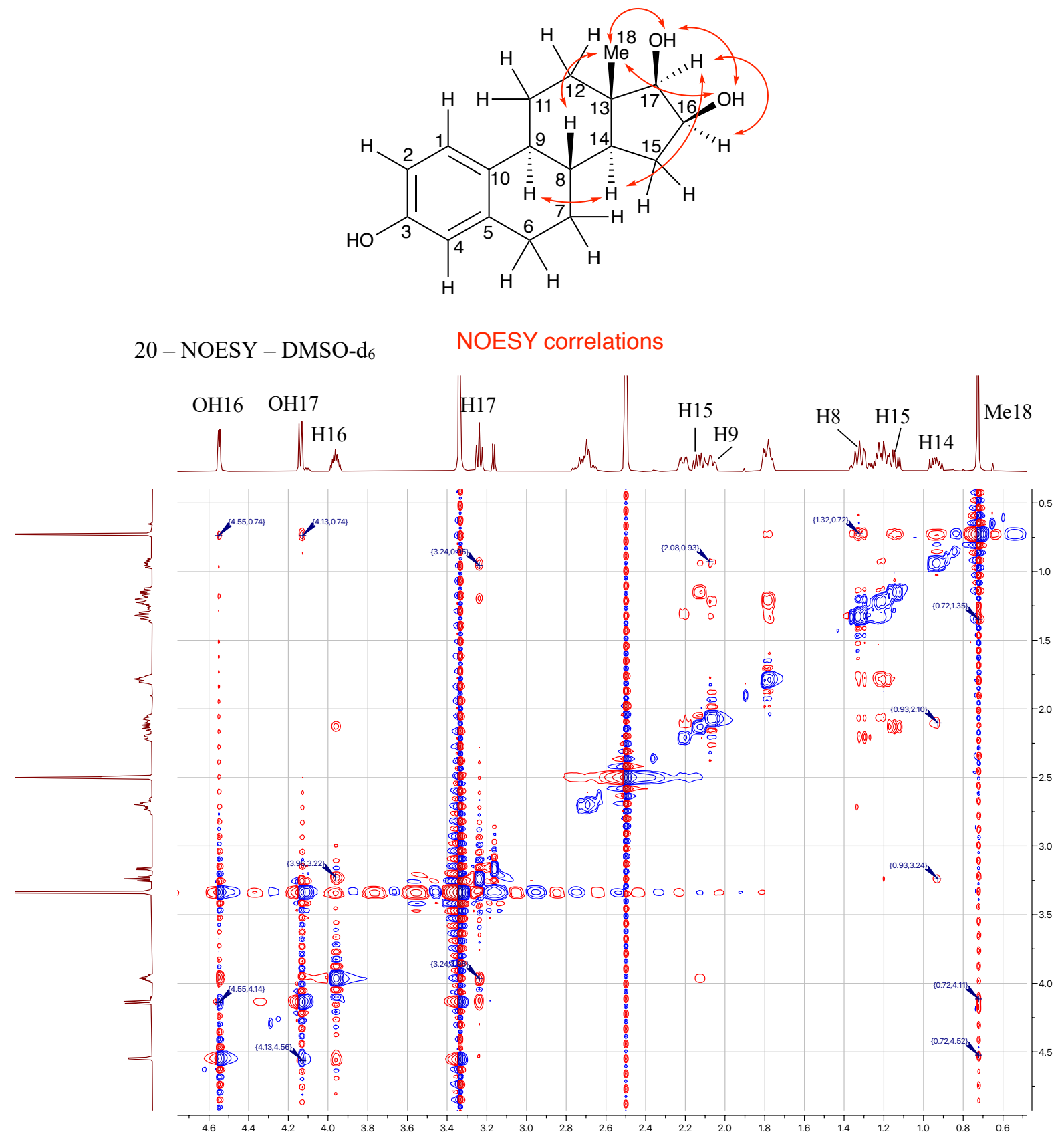

H14 assigned by COSY from H15, assigned by COSY from H16.

H9 assigned by HSQC from C9, assigned by HMBC from H1.

H8 assigned by COSY from $\mathrm{H} 9$ and $\mathrm{H} 15$. 
( \pm )-1-(cis-3,4-dihydroxypiperidin-1-yl)-3-(4,5-diphenyloxazol-2-yl)propan-1-one (21)
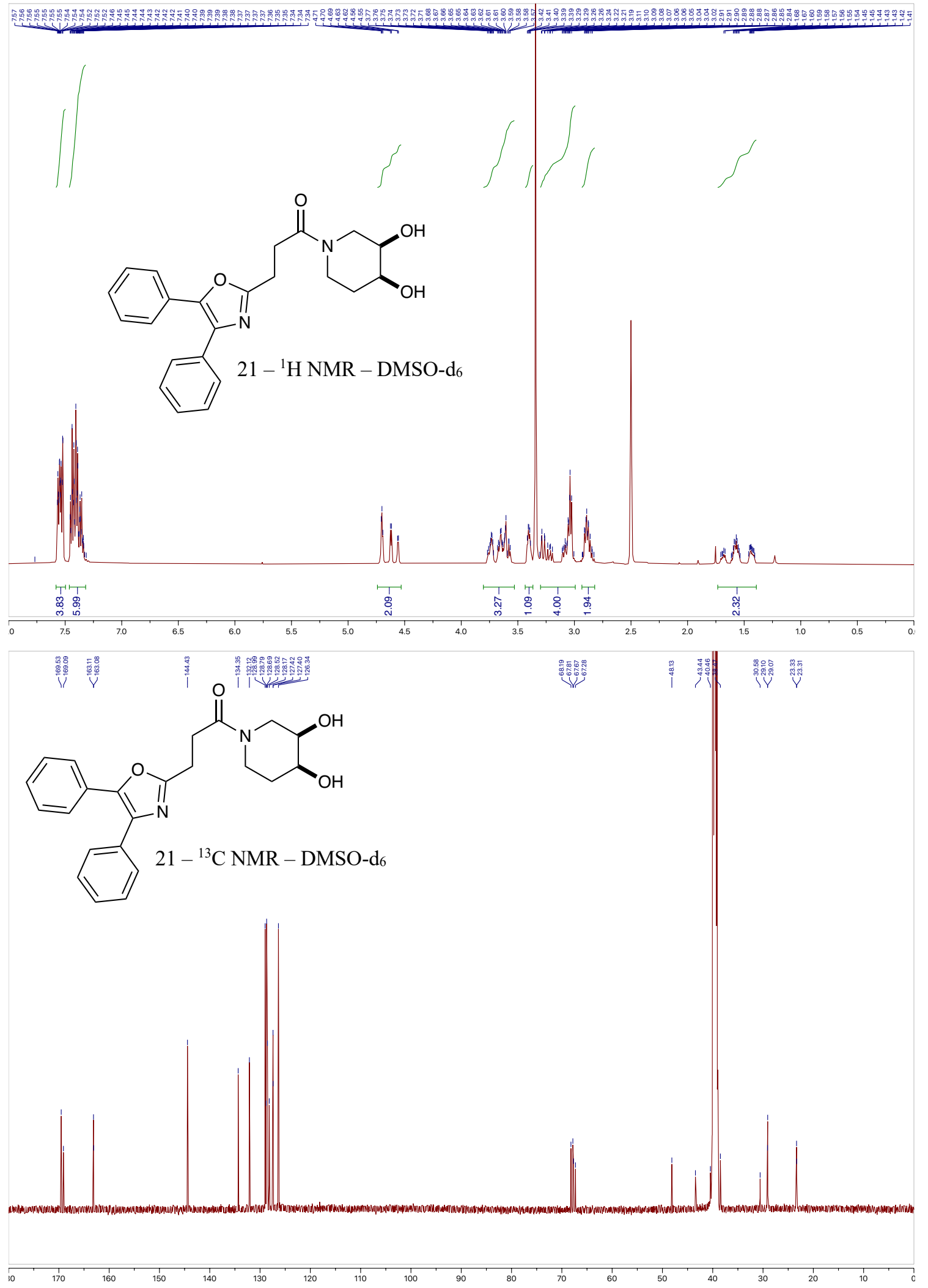
$100{ }^{\circ} \mathrm{C}^{1} \mathrm{H}$ NMR: Peak convergence indicates presence of amide rotamers.

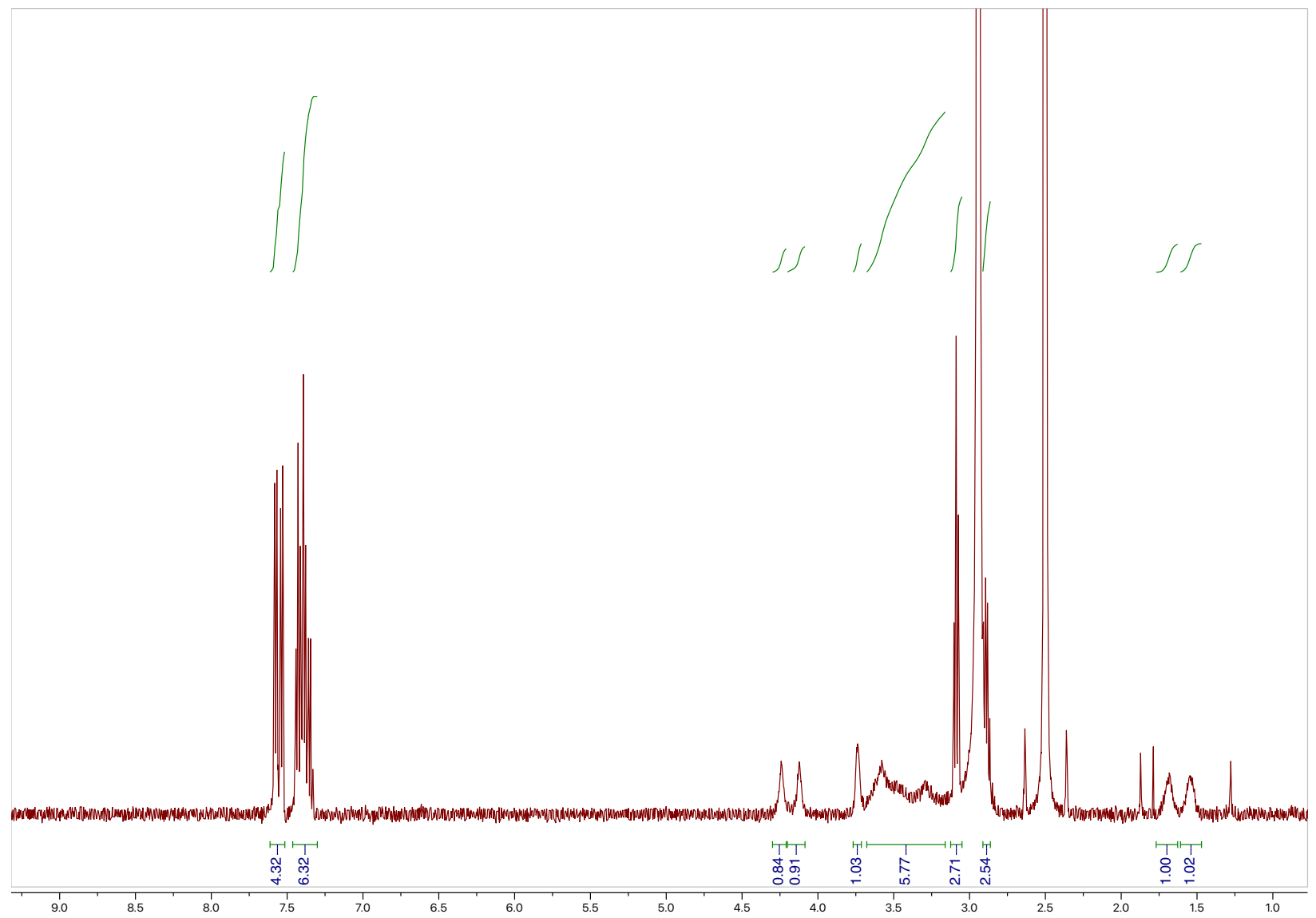


cis-1,3-cyclohexanediol (22)

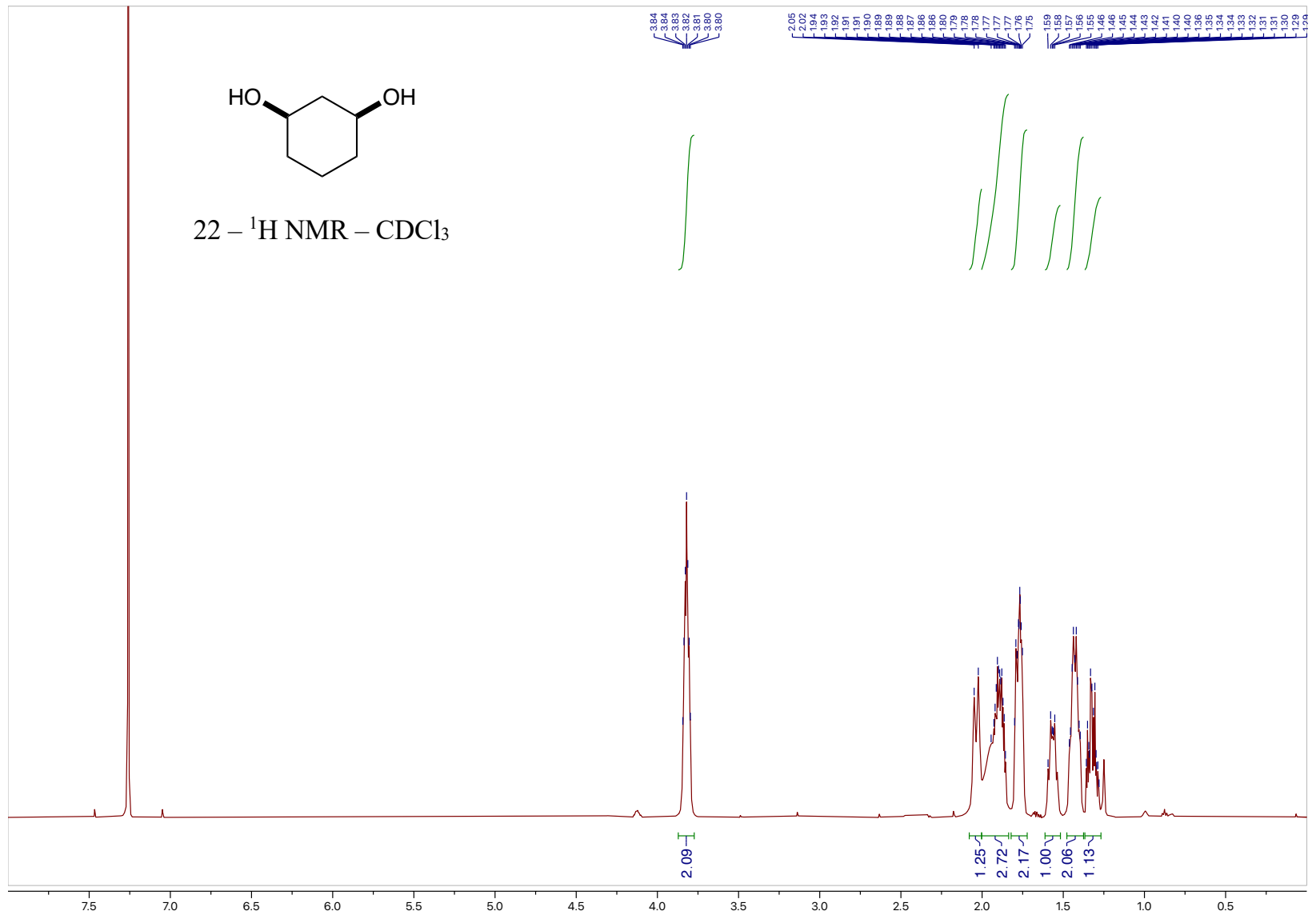


cis-1,3-cyclopentanediol (23)

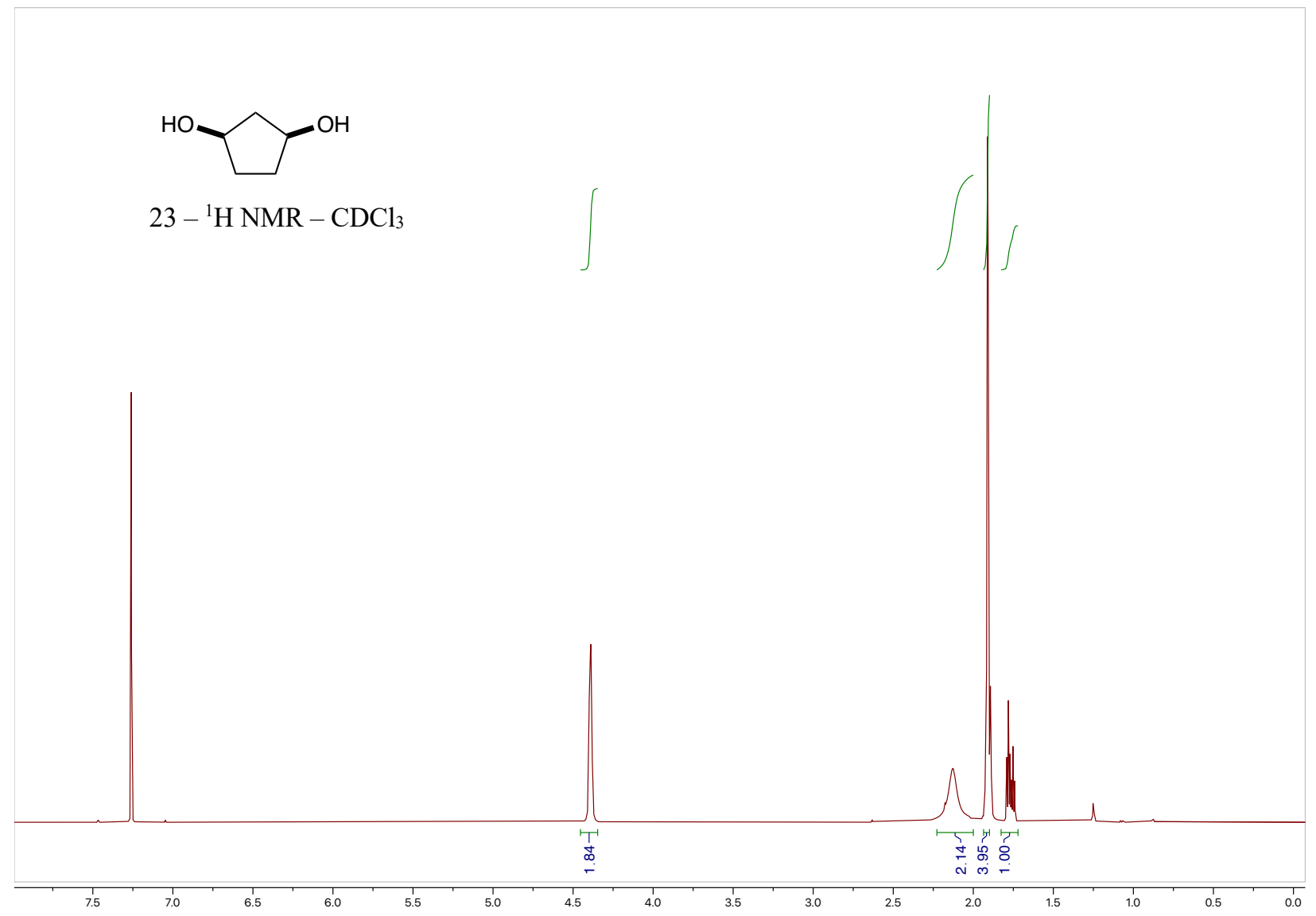


( \pm )-cis-2-(hydroxymethyl)cyclopentanol (24)

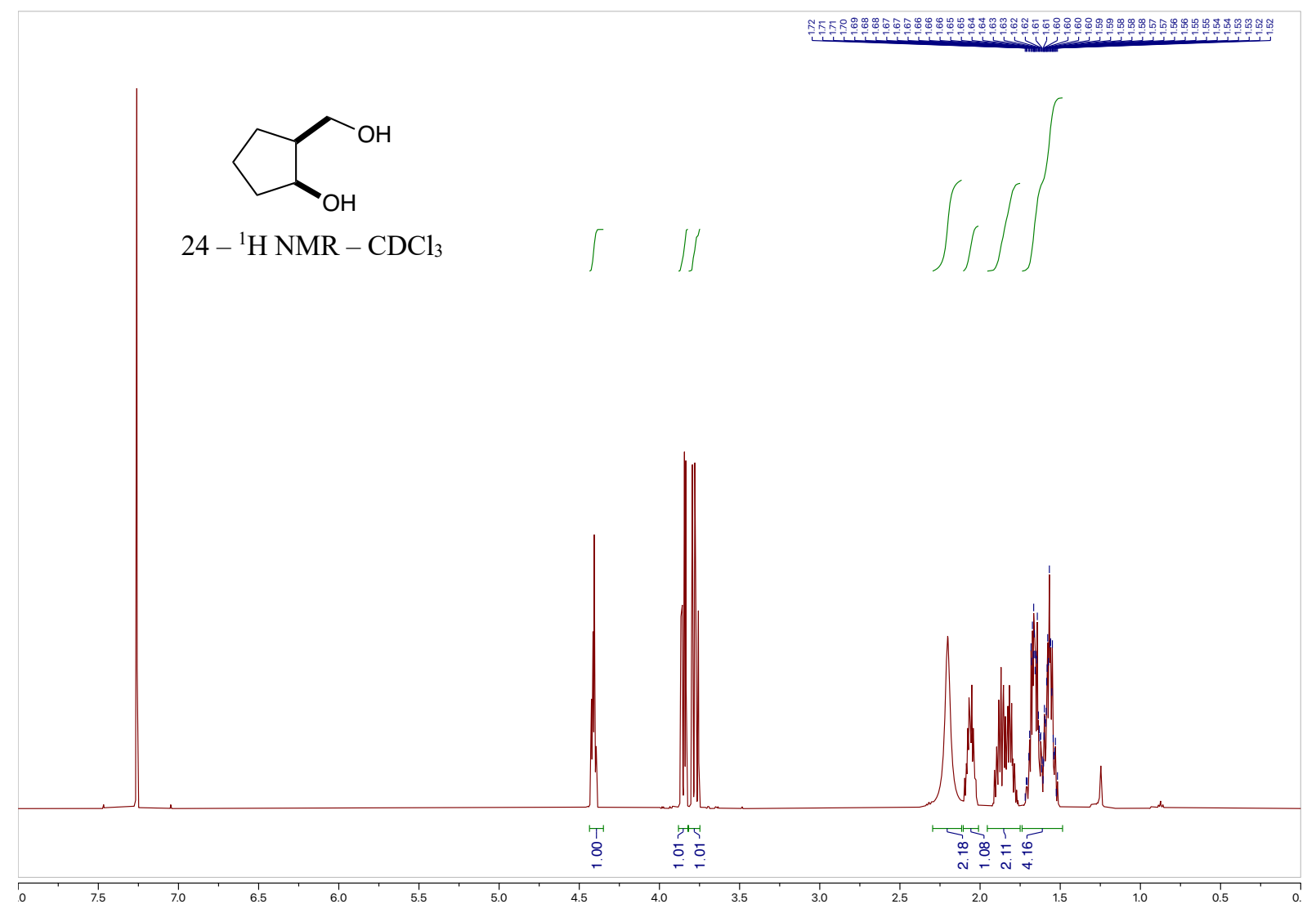




\section{( \pm )-cis-3-hydroxy-4-(hydroxymethyl)tetrahydrofuran (25)}
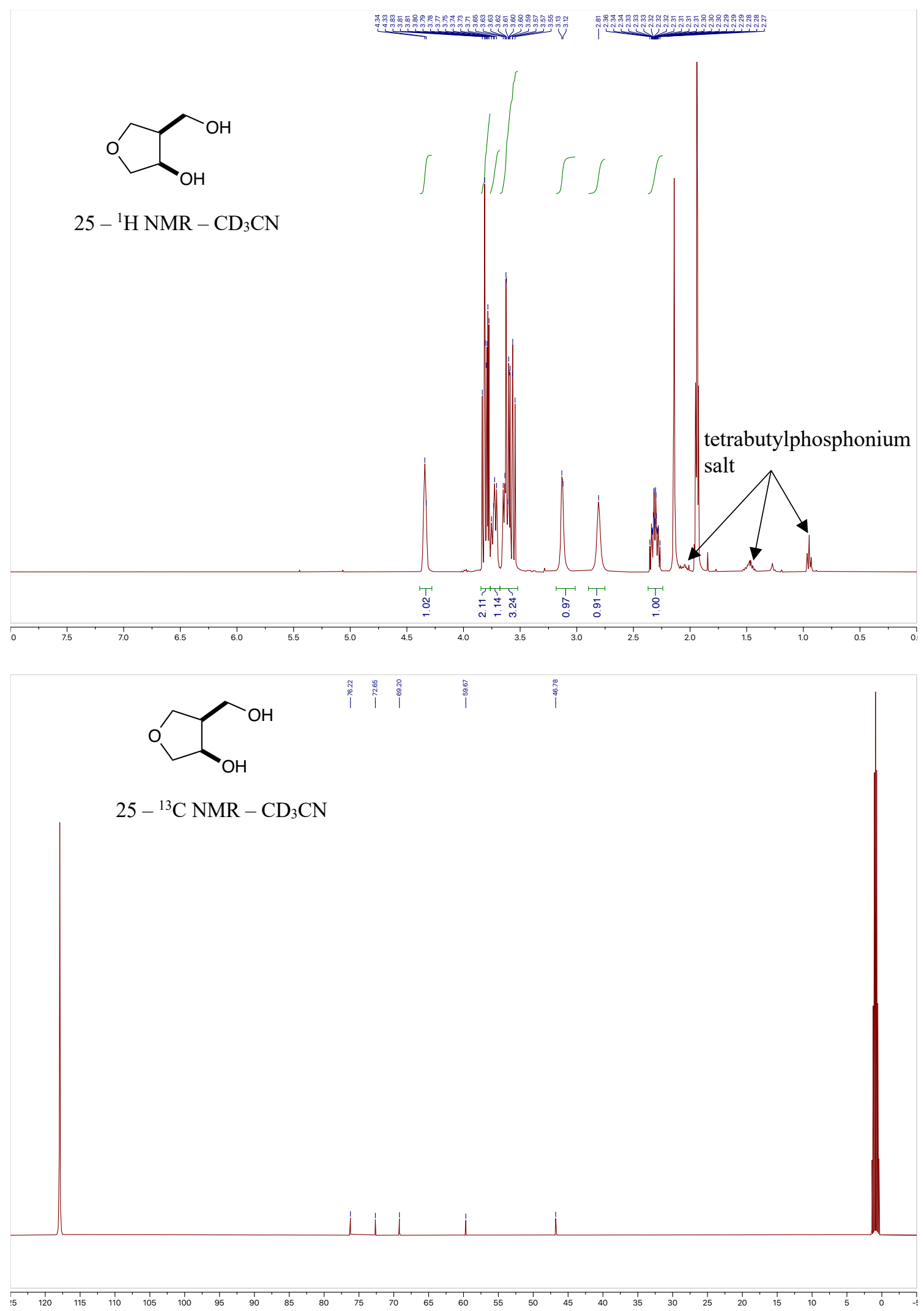


\section{$(1 R, 2 S)$-2-(hydroxymethyl)cyclohexanol (26)}

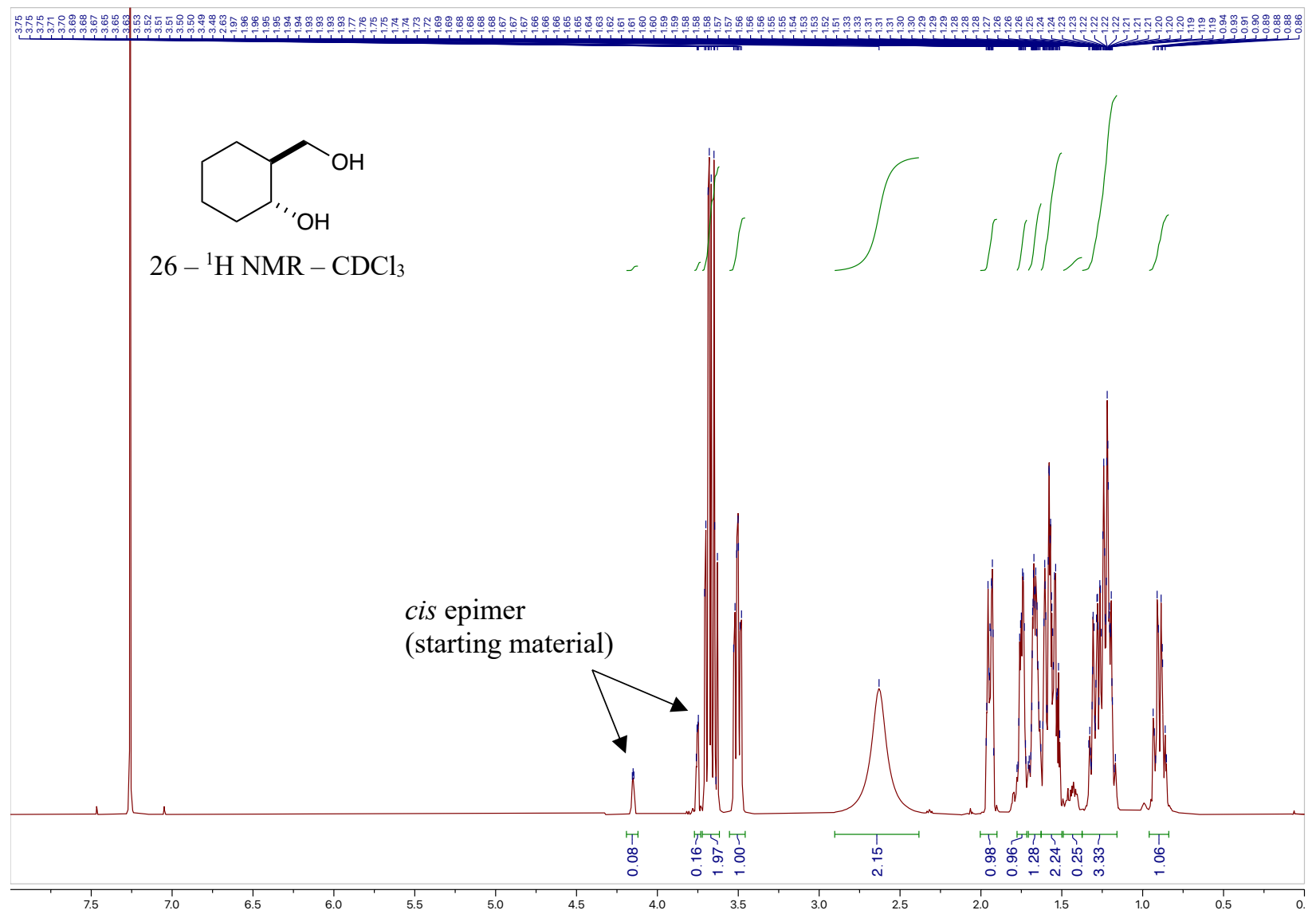


( \pm )- $N$-Boc-trans-3-hydroxy-4-(hydroxymethyl)piperidine (27)

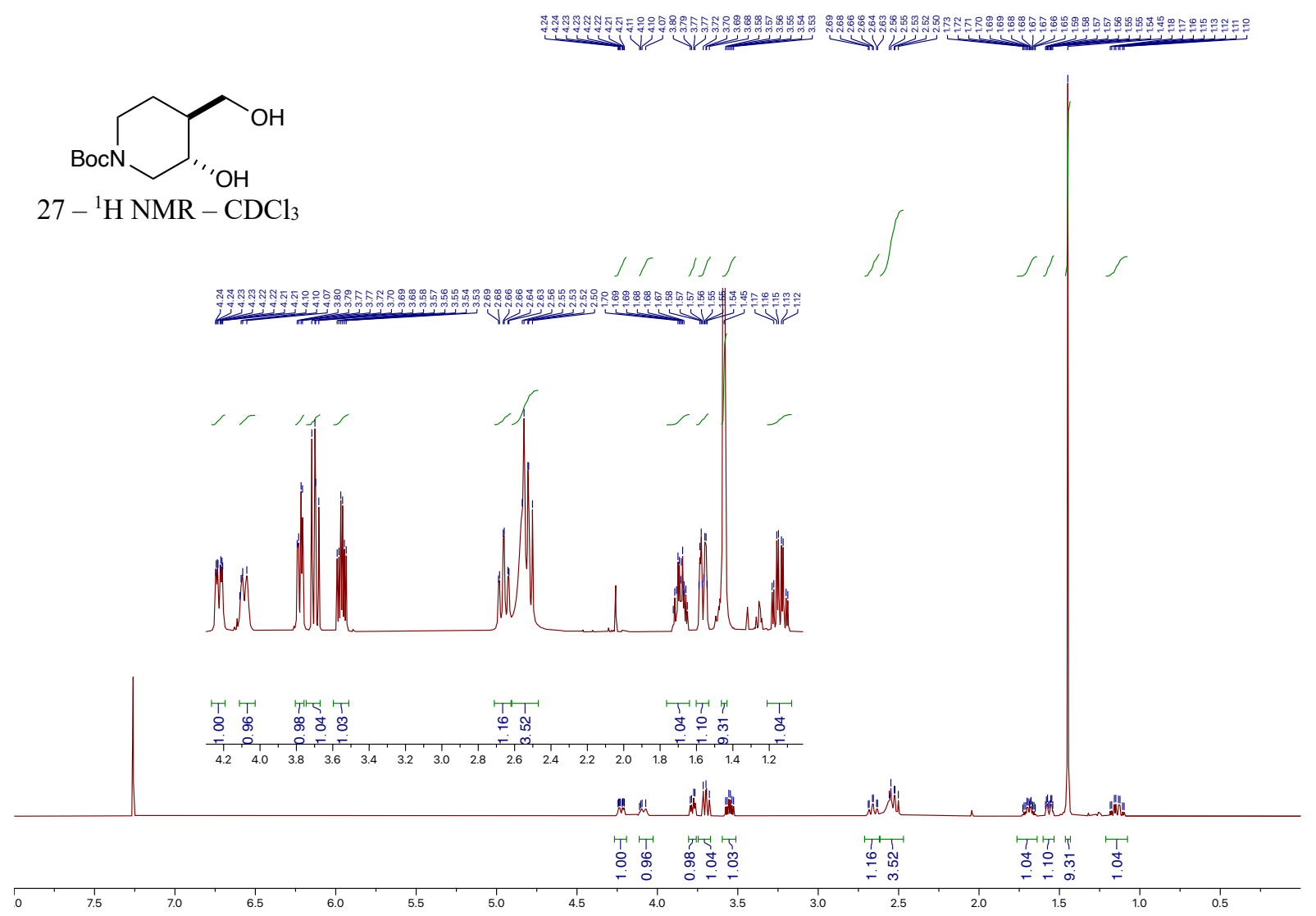




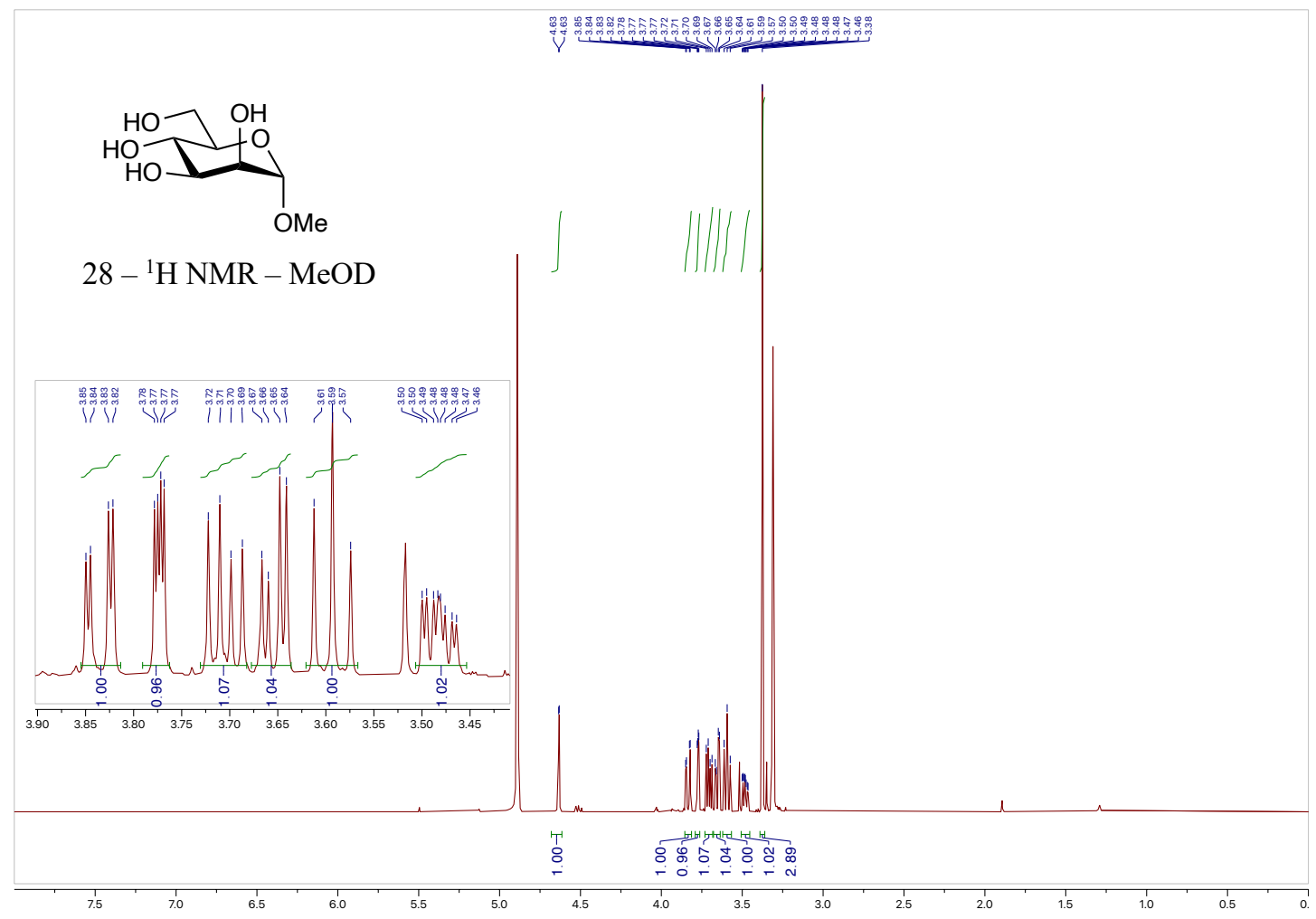

\section{Analytical yield ${ }^{1} \mathrm{H}$ NMR $-\mathrm{CD}_{3} \mathrm{CN}$}

Mesitylene (0.2 eq, 60\% Ar-H peak height)

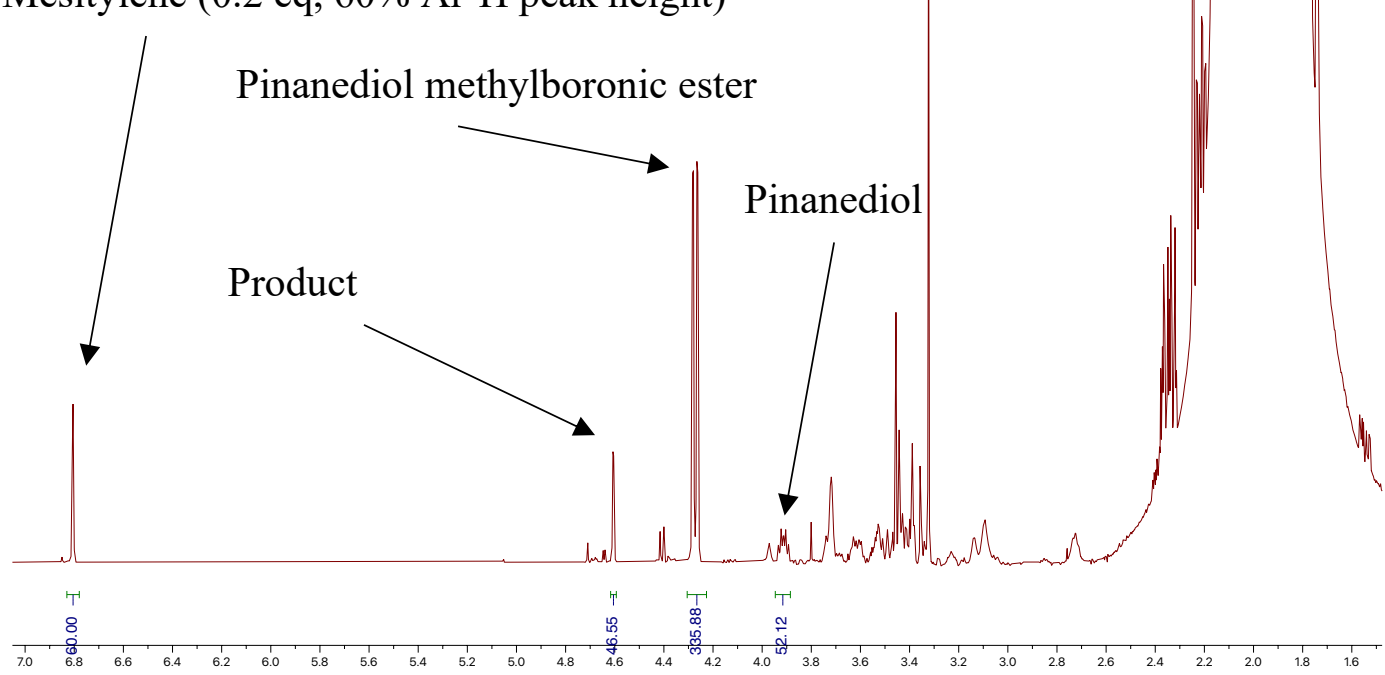


Supporting Information

\section{D- $\beta$-methylallose (29)}

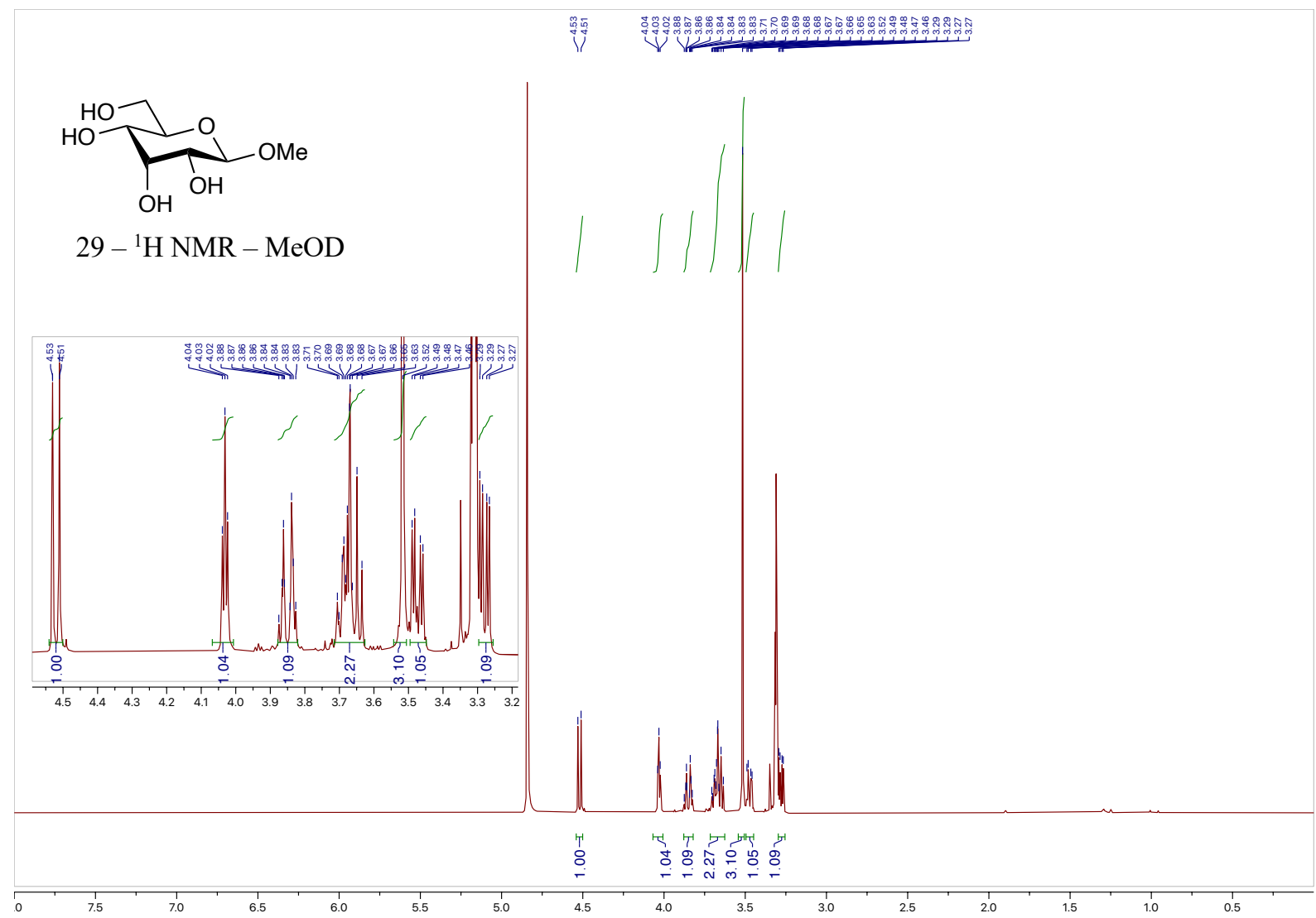




\section{allo-dapagliflozin (30)}
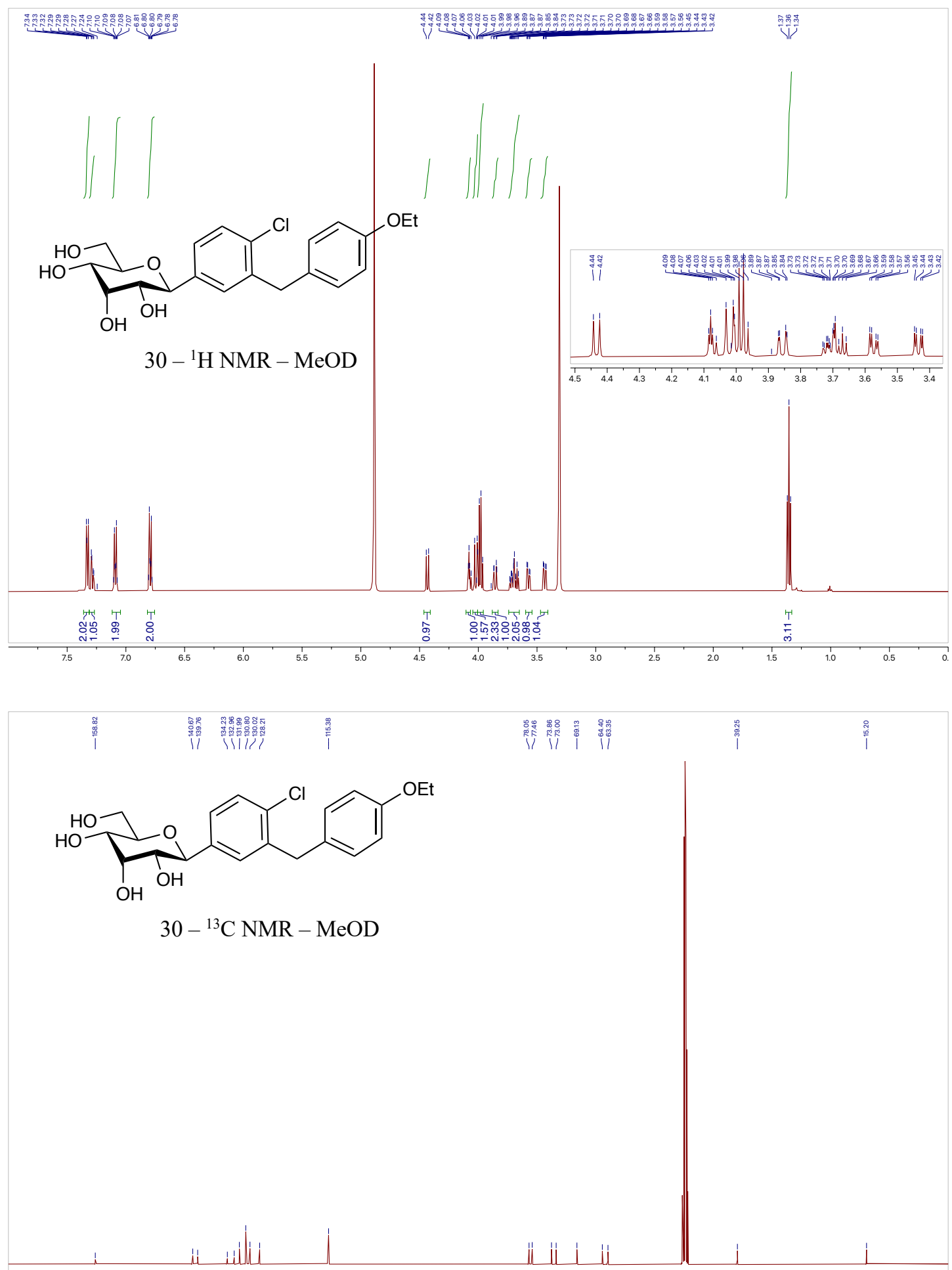

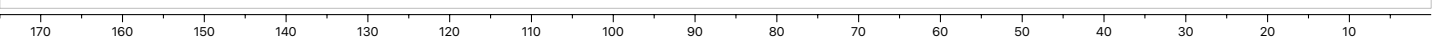


Supporting Information

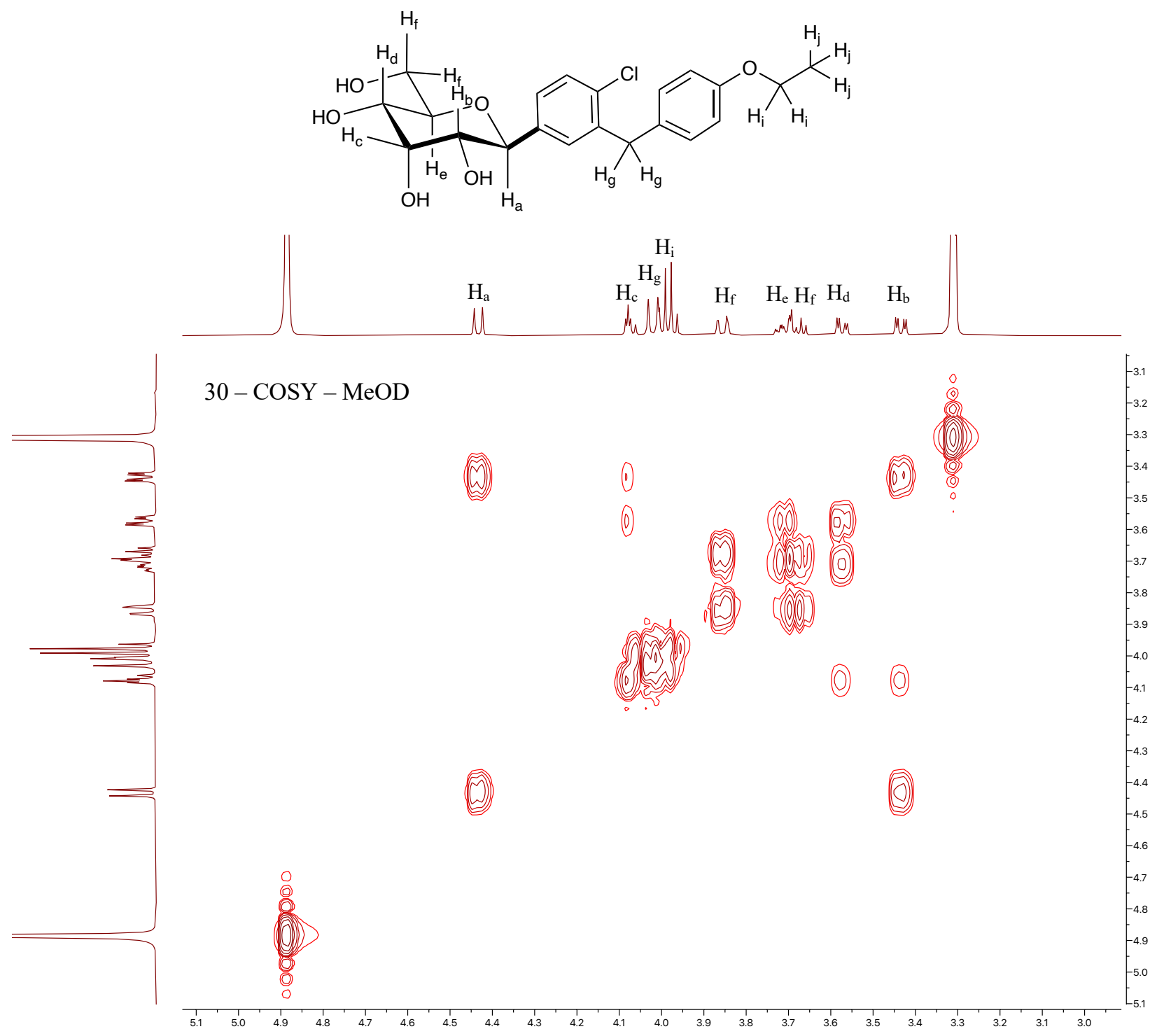


Supporting Information

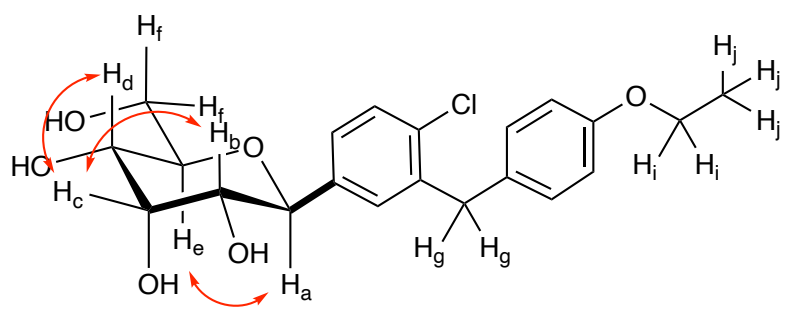

NOESY correlations

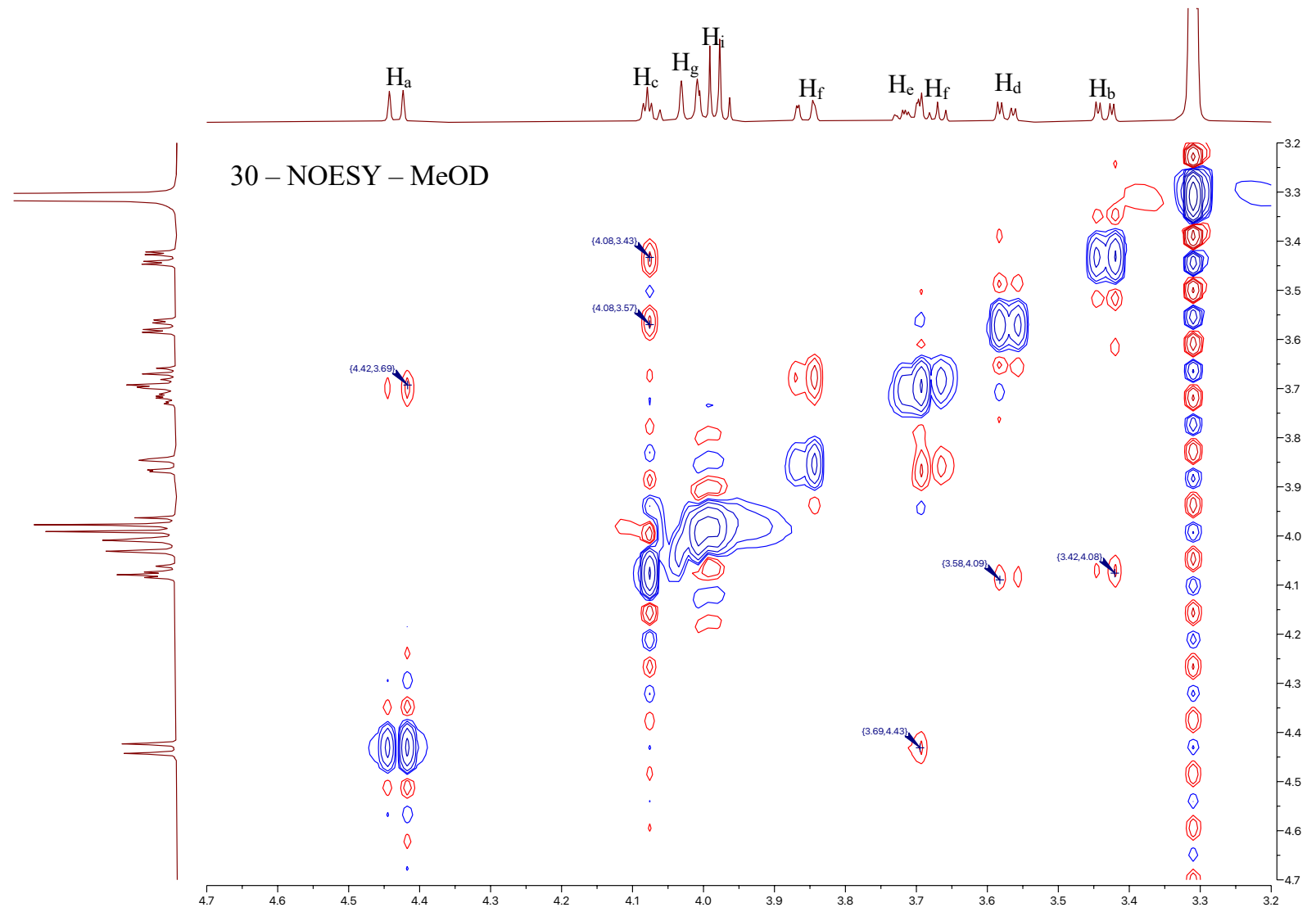




\section{1) References cited}

1. Perry, I. B.; Brewer, T. F.; Sarver, P. J.; Schultz, D. M.; DiRocco, D. A.; MacMillan, D. W. C. Direct arylation of strong aliphatic C-H bonds. Nature 2018, 560, 70-75.

2. Theil, F.; Ballschuh, S. Chemoenzymatic synthesis of both enantiomers of cispentacin. Tetrahedron: Asymmetry 1996, 7, 3565-3572.

3. Kasturi, S. P.; Surarapu, S.; Uppalanchi, S.; Dwivedi, S.; Yogeeswari, P.; Sigalapalli, D. K.; Bathini, N. B.; Ethiraj, K. S.; Anireddy, J. S. Synthesis, molecular modeling and evaluation of a-glucosidase inhibition activity of 3,4-dihydroxy piperidines. Eur. J. Med. Chem. 2018, 150, 3952 .

4. Cavdar, H.; Saracoglu, N. Ring opening of epoxides with NaHSO4: isolation of $\beta$-hydroxy sulfate esters and an effective synthesis for trans-diols. Tetrahedron 2009, 65, 985-989.

5. Mecozzi, F.; Dong, J. J.; Saisaha, P.; Browne, W. R. Oxidation of Vicinal Diols to $\alpha-$ Hydroxy Ketones with $\mathrm{H} 2 \mathrm{O} 2$ and a Simple Manganese Catalyst. Eur. J. Org. Chem. 2017, 2017, 6919-6925.

6. Carman, R.; Fletcher, M. The four (4R)-p-menthane-1,2,8-triols. Aust. J. Chem. 1984, 37, 2129-2136.

7. Barili, P. L.; Berti, G.; Mastrorilli, E. Regio- and stereochemistry of the acid catalyzed and of a highly enantioselective enzymatic hydrolysis of some epoxytetrahydrofurans. Tetrahedron 1993, 49, 6263-6276.

8. (a) Kano, T.; Hato, Y.; Maruoka, K. Design of a C2-symmetric chiral pyrrolidine-based amino sulfonamide: application to anti-selective direct asymmetric Mannich reactions. Tetrahedron Lett. 2006, 47, 8467-8469. (b) Xie, F.; Yang, F.; Liang, Y.; Li, L.; Xia, Y.; Jiang, F.; Liu, W.; Qi, Y.; Chowdhury, S. R.; Xie, D.; Fu, L. Investigation of stereoisomeric bisarylethenesulfonic acid esters for discovering potent and selective PTP1B inhibitors. Eur. J. Med. Chem. 2019, 164, 408-422.

9. Rodríguez Sarmiento, R. M. a.; Wirz, B.; Iding, H. Chemoenzymatic preparation of nonracemic N-Boc-pyrrolidine-3,4-dicarboxylic acid 3-ethyl esters and their 4-hydroxymethyl derivatives. Tetrahedron: Asymmetry 2003, 14, 1547-1551.

10. Marradi, M.; Cicchi, S.; Sansone, F.; Casnati, A.; Goti, A. Low-generation dendrimers with a calixarene core and based on a chiral C2-symmetric pyrrolidine as iminosugar mimics. Beilstein J. Org. Chem. 2012, 8, 951-957.

11. Kasun, Z. A.; Geary, L. M.; Krische, M. J. Ring expansion of cyclic 1,2-diols to form medium sized rings via ruthenium catalyzed transfer hydrogenative [4+2] cycloaddition. Chem. Commun. 2014, 50, 7545-7547.

12. (a) Gatling, S. C.; Jackson, J. E. Reactivity Control via Dihydrogen Bonding: Diastereoselection in Borohydride Reductions of $\alpha$-Hydroxyketones. J. Am. Chem. Soc. 1999, 121, 
8655-8656. (b) Cuccu, F.; Serusi, L.; Luridiana, A.; Secci, F.; Caboni, P.; Aitken, D. J.; Frongia, A. Tandem Wittig Reaction-Ring Contraction of Cyclobutanes: A Route to Functionalized Cyclopropanecarbaldehydes. Org. Lett. 2019, 21, 7755-7758.

13. Farre, A.; Soares, K.; Briggs, R. A.; Balanta, A.; Benoit, D. M.; Bonet, A. Amine Catalysis for the Organocatalytic Diboration of Challenging Alkenes. Chem. - Eur. J. 2016, 22, 1755217556.

14. Li, X.; Tanasova, M.; Vasileiou, C.; Borhan, B. Fluorinated Porphyrin Tweezer: A Powerful Reporter of Absolute Configuration for erythro and threo Diols, Amino Alcohols, and Diamines. J. Am. Chem. Soc. 2008, 130, 1885-1893.

15. Zeror, S.; Collin, J.; Fiaud, J.-C.; Zouioueche, L. A. Enantioselective ketoester reductions in water: a comparison between microorganism- and ruthenium-catalyzed reactions. Tetrahedron: Asymmetry 2010, 21, 1211-1215.

16. Wächter, M.; Rüedi, P. Synthesis and Characterization of the Enantiomerically Pure cisand trans-2,4-Dioxa-3-fluoro-3-phosphadecalins as Inhibitors of Acetylcholinesterase. Chem. Biodiversity 2009, 6, 283-294.

17. (a) Gijsen, H. J. M.; De Cleyn, M. J. A.; Love, C. J.; Surkyn, M.; Van Brandt, S. F. A.; Verdonck, M. G. C.; Moens, L.; Cuypers, J.; Bosmans, J.-P. R. M. A. Development of two diastereoselective routes towards trans-4-aminomethyl-piperidin-3-ol building blocks. Tetrahedron 2008, 64, 2456-2464. (b) Koudih, R.; Gilbert, G.; Dhilly, M.; Abbas, A.; Barré, L.; Debruyne, D.; Sobrio, F. Radiolabelling of 1,4-disubstituted 3-[18F]fluoropiperidines and its application to new radiotracers for NR2B NMDA receptor visualization. Org. Biomol. Chem. 2012, 10, 8493-8500.

18. Le, C. C.; Wismer, M. K.; Shi, Z.-C.; Zhang, R.; Conway, D. V.; Li, G.; Vachal, P.; Davies, I. W.; MacMillan, D. W. C. A General Small-Scale Reactor To Enable Standardization and Acceleration of Photocatalytic Reactions. ACS. Cent. Sci. 2017, 3, 647-653.

19. (a) Dimakos, V.; Gorelik, D.; Su, H. Y.; Garrett, G. E.; Hughes, G.; Shibayama, H.; Taylor, M. S. Site-selective redox isomerizations of furanosides using a combined arylboronic acid/photoredox catalyst system. Chem. Sci. 2020, 11, 1531-1537. (b) Carder, H. M.; Suh, C. E.; Wendlandt, A. E. A Unified Strategy to Access 2- and 4-Deoxygenated Sugars Enabled by Manganese-Promoted 1,2-Radical Migration. J. Am. Chem. Soc. 2021, 143, 13798-13805.

20. Kothe, T.; Martschke, R.; Fischer, H. Photoreactions of the decatungstate anion W10O324- with organic substrates in solution studied by EPR and kinetic absorption spectroscopy: an example for the persistent radical effect. J. Chem. Soc., Perkin Trans. 2 1998, 503-508.

21. McKillop, A.; Koyunçu, D.; Krief, A.; Dumont, W.; Renier, P.; Trabelsi, M. Efficicient, high yield, oxidation of thiols and selenols to disulphides and diselenides. Tetrahedron Lett. 1990, $31,5007-5010$. 
22. Ravelli, D.; Fagnoni, M.; Fukuyama, T.; Nishikawa, T.; Ryu, I. Site-Selective C-H Functionalization by Decatungstate Anion Photocatalysis: Synergistic Control by Polar and Steric Effects Expands the Reaction Scope. ACS Catal. 2018, 8, 701-713.

23. (a) Yamase, T.; Takabayashi, N.; Kaji, M. Solution photochemistry of tetrakis(tetrabutylammonium) decatungstate(VI) and catalytic hydrogen evolution from alcohols. J. Chem. Soc., Dalton Trans. 1984, 793-799. (b) Yamase, T.; Usami, T. Photocatalytic dimerization of olefins by decatungstate(VI), [W10O32]4-, in acetonitrile and magnetic resonance studies of photoreduced species. J. Chem. Soc., Dalton Trans. 1988, 183-190. (c) Larsen, A. G.; Holm, A. H.; Roberson, M.; Daasbjerg, K. Substituent Effects on the Oxidation and Reduction Potentials of Phenylthiyl Radicals in Acetonitrile. J. Am. Chem. Soc. 2001, 123, 1723-1729.

24. Wang, Y.; Carder, H. M.; Wendlandt, A. E. Synthesis of rare sugar isomers through siteselective epimerization. Nature 2020, 578, 403-408.

25. Frisch, M. J., Trucks, G. W., Schlegel, H. B., Scuseria, G. E., Robb, M. A., Cheeseman, J. R., Scalmani, G., Barone, V., Petersson, G. A., Nakatsuji, H. et al. Gaussian 16. Gaussian, Inc.: Wallingford, CT.

26. (a) Vosko, S. H.; Wilk, L.; Nusair, M. Accurate spin-dependent electron liquid correlation energies for local spin density calculations: a critical analysis. Can. J. Phys. 1980, 58, 1200-1211. (b) Lee, C.; Yang, W.; Parr, R. G. Development of the Colle-Salvetti correlation-energy formula into a functional of the electron density. Phys. Rev. B 1988, 37, 785-789. (c) Becke, A. D. Densityfunctional thermochemistry. III. The role of exact exchange. J. Chem. Phys. 1993, 98, 5648-5652. (d) Stephens, P. J.; Devlin, F. J.; Chabalowski, C. F.; Frisch, M. J. Ab Initio Calculation of Vibrational Absorption and Circular Dichroism Spectra Using Density Functional Force Fields. $J$. Phys. Chem. 1994, 98, 11623-11627.

27. Grimme, S.; Antony, J.; Ehrlich, S.; Krieg, H. A consistent and accurate ab initio parametrization of density functional dispersion correction (DFT-D) for the 94 elements H-Pu. $J$. Chem. Phys. 2010, 132, 154104.

28. Marenich, A. V.; Cramer, C. J.; Truhlar, D. G. Universal Solvation Model Based on Solute Electron Density and on a Continuum Model of the Solvent Defined by the Bulk Dielectric Constant and Atomic Surface Tensions. J. Phys. Chem. B 2009, 113, 6378-6396.

29. Laserna, V.; Fiorani, G.; Whiteoak, C. J.; Martin, E.; Escudero-Adán, E.; Kleij, A. W. Carbon Dioxide as a Protecting Group: Highly Efficient and Selective Catalytic Access to Cyclic cis-Diol Scaffolds. Angewandte Chemie International Edition 2014, 53, 10416-10419.

30. Brawn, R. A.; Guimarães, C. R. W.; McClure, K. F.; Liras, S. An Efficient Synthesis of Bridged Heterocycles from an Ir(I) Bis-Amination/Ring-Closing Metathesis Sequence. Organic Letters 2012, 14, 4802-4805.

31. Plietker, B.; Niggemann, M.; Pollrich, A. The acid accelerated ruthenium-catalysed dihydroxylation. Scope and limitations. Organic \& Biomolecular Chemistry 2004, 2, 1116-1124. 
32. Abraham, R. J.; Chambers, E. J.; Thomas, W. A. Conformational analysis. Part 21. Conformational isomerism in cis-cyclohexane-1,3-diol. J. Chem. Soc., Perkin Trans. 2 1993, 1061-1066.

33. Erden, I.; Gärtner, C.; Azimi, M. S. Triphenylphosphine Reduction of Saturated Endoperoxides. Org. Lett. 2009, 11, 3986-3989.

34. Kinast, G.; Tietze, L.-F. Iridoide, V Biogeneseähnliche Synthese von Secologanin- und Swerosid-aglyconmethyläther. Chem. Ber. 1976, 109, 3626-3639.

35. Li, W.; Koike, K.; Asada, Y.; Yoshikawa, T.; Nikaido, T. Biotransformation of lowmolecular-weight alcohols by Coleus forskohlii hairy root cultures. Carbohydr. Res. 2003, 338, 729-731. 